\title{
Hydrogeologic analysis of streamflow in relation to underground mining in northern West Virginia
}

\author{
David Robert Gill \\ West Virginia University
}

Follow this and additional works at: https://researchrepository.wvu.edu/etd

\section{Recommended Citation}

Gill, David Robert, "Hydrogeologic analysis of streamflow in relation to underground mining in northern West Virginia" (2000). Graduate Theses, Dissertations, and Problem Reports. 1157.

https://researchrepository.wvu.edu/etd/1157

This Thesis is protected by copyright and/or related rights. It has been brought to you by the The Research Repository @ WVU with permission from the rights-holder(s). You are free to use this Thesis in any way that is permitted by the copyright and related rights legislation that applies to your use. For other uses you must obtain permission from the rights-holder(s) directly, unless additional rights are indicated by a Creative Commons license in the record and/ or on the work itself. This Thesis has been accepted for inclusion in WVU Graduate Theses, Dissertations, and Problem Reports collection by an authorized administrator of The Research Repository @ WVU. For more information, please contact researchrepository@mail.wvu.edu. 
HYDROGEOLOGIC ANALYSIS OF STREAMFLOW IN RELATION TO UNDERGROUND MINING IN NORTHERN WEST VIRGINIA

\author{
D. Robert Gill \\ Thesis submitted to the \\ College of Arts and Sciences \\ at West Virginia University \\ In partial fulfillment of the requirements \\ for the degree of
}

Masters of Science

in

Geology

by

Henry W. Rauch, Ph.D., Co-Chair

J. Steven Kite, Ph.D., Co-Chair Jack Renton, Ph.D.

Ronald D. Evaldi

Department of Geology

Morgantown, West Virginia

2000

Keywords: Longwall Coal Mining, Stream Dewatering, Mining Environmental Impacts, Stream Sediments 


\begin{abstract}
Hydrogeologic Analysis of Streamflow in Relation to Underground Mining in Northern West Virginia

\section{Robert Gill}

Land subsidence, caused by longwall mining, has a negative effect on overlying watersheds. Nine streams were monitored from their headwaters to their mouths for discharge, temperature, conductivity, alluvium thickness, and alluvium sediment size. Seven streams are located over undermined longwall panels, with two located over non-undermined areas. Discharge data shows that non-undermined watersheds do not experience stream dewatering, regardless of alluvium thickness or sediment size. Streams located over active or recently mined longwall panels experience water loss that ranges from slight to total. Impacted streams with overall increases in conductivity and decreases in water temperature suggest that lost streamflow travels as underflow, mixing with more conductive, cooler ground water. A thin alluvial cover and poor sorting of streambed sediments appear to prolong stream dewatering. The excavation of stream channels did not remedy dewatering impacts, but returns a positive drainage gradient to the stream channel. 


\section{ACKNOWLEDGEMENTS}

My deepest thanks and gratitude are extended to all who have made this project possible. I would especially like to thank Dr. Henry Rauch for the countless hours spent in his office and for the guidance and tutelage that he has shown throughout the entire project; Dr. Steve Kite for his help, suggestions and

support; Dr. John Renton for his time and suggestions; and Mr. Ron Evaldi for his technical suggestions and time.

I would also like to thank Mine Z coal company personnel for their help, suggestions, time, and partial funding for this project. Thanks is extended to the construction company that manufactured the weirs used in this project and also to the private land owners who supplied me with information, stories, and permission to "walk around in their creek". Dr. Shumaker provided me with some well needed funding for this project, and for that I am grateful.

Last but not least, I want to thank my family and friends for their constant encouragement and support. Special thanks are given to my parents, Donald and Barbara, and brother, Mike. I also had free help with my fieldwork from my friends, Peter Fahringer and Tanner Sattler, and my fiancée, Kelly. If it weren't for their help, I would probably still be conducting field work. 


\section{TABLE OF CONTENTS}

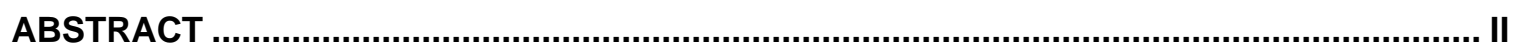

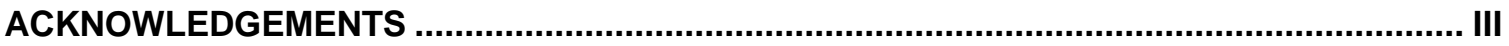

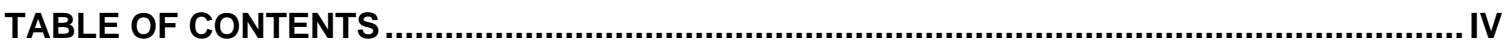

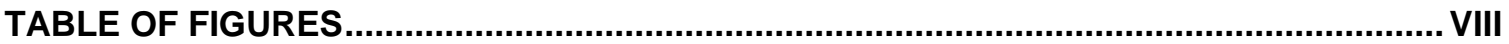

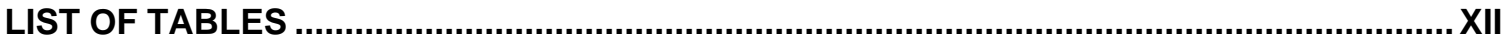

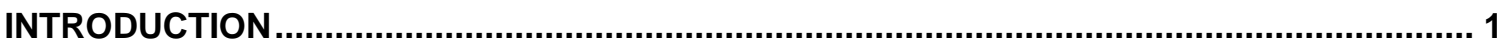

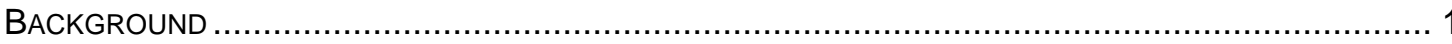

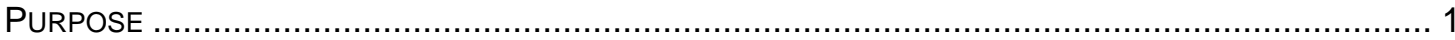

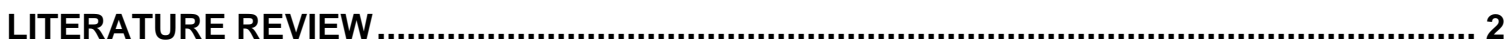

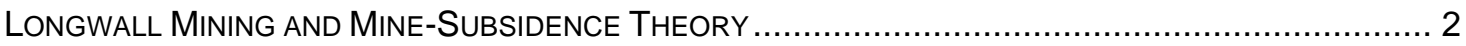

EfFects of Mining on Ground W Ater And StReamflow Outside the Study AREA ............... 6

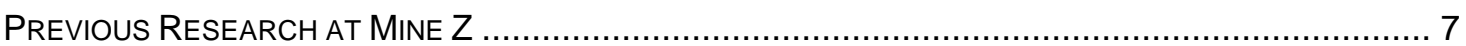

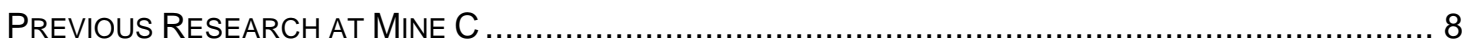

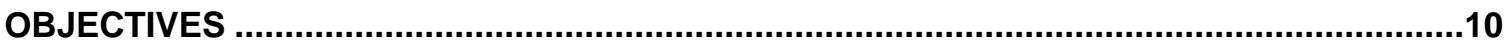

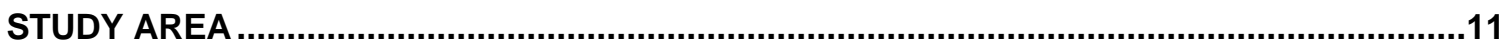

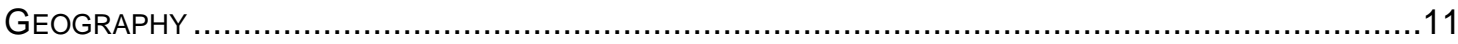

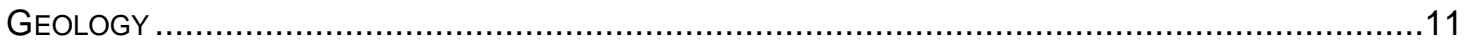

METHODS OF INVESTIGATION

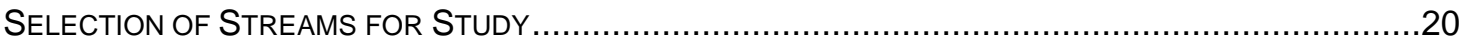

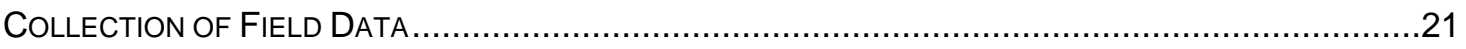

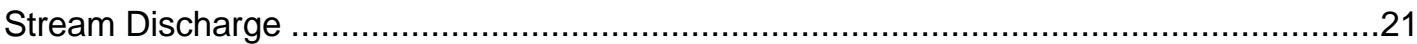




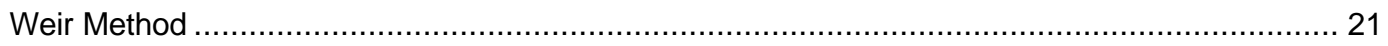

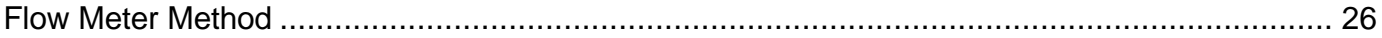

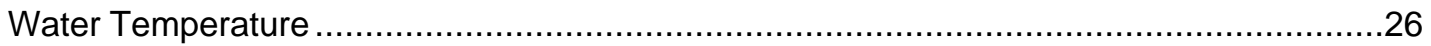

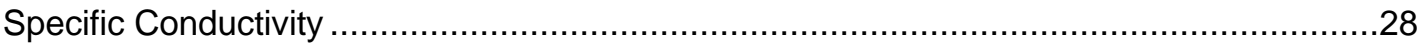

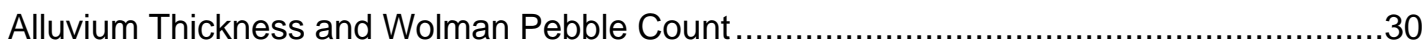

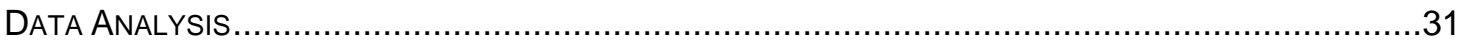

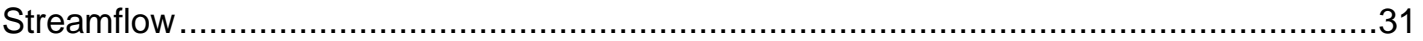

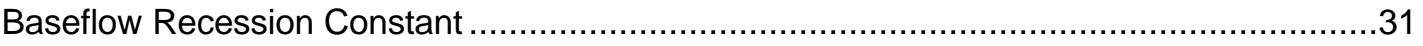

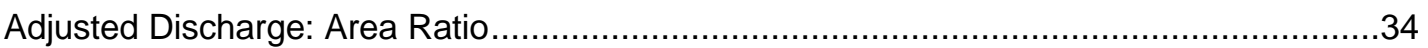

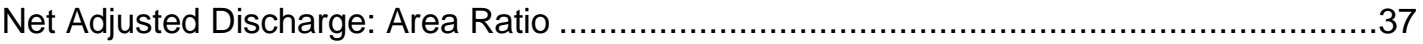

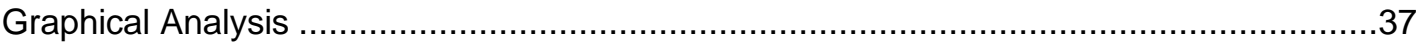

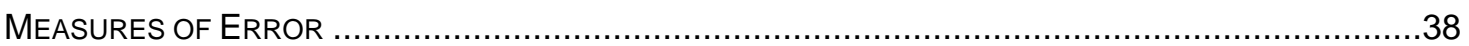

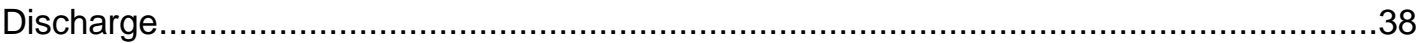

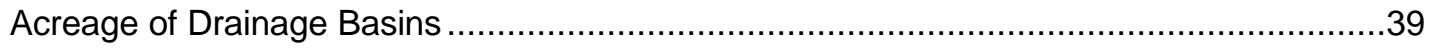

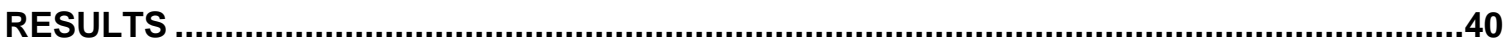

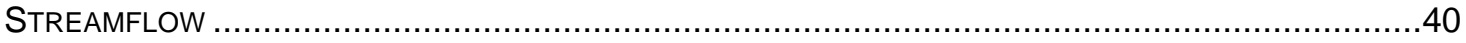

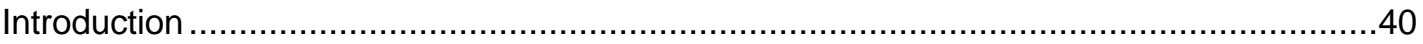

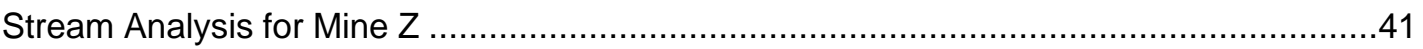

Stream X and Stream Y (August 9, 1999 monitoring)............................................................. 41

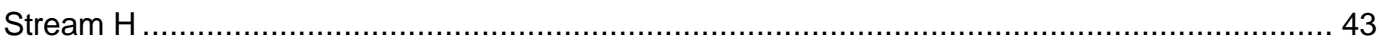

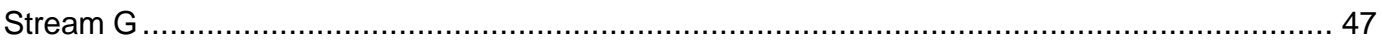

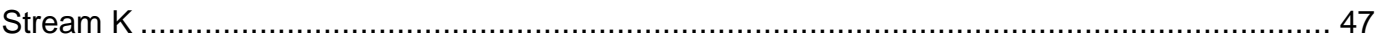

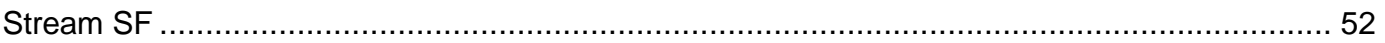

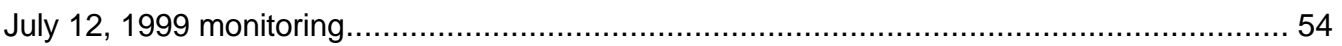

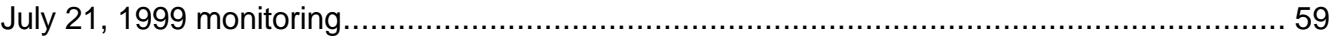

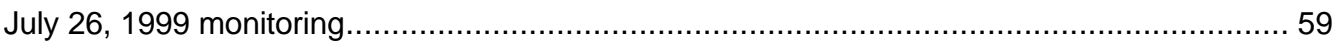

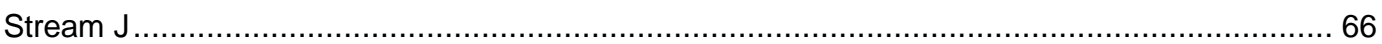

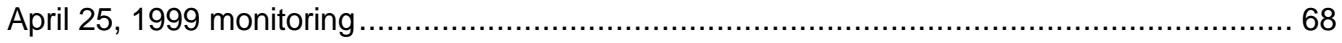

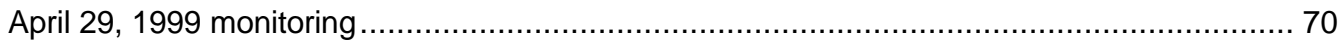




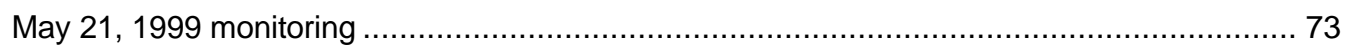

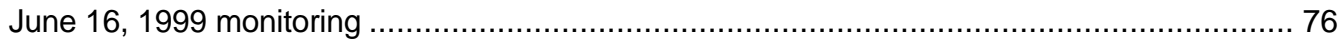

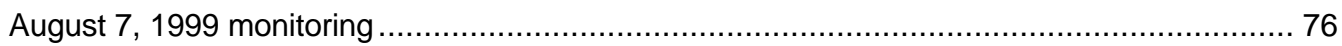

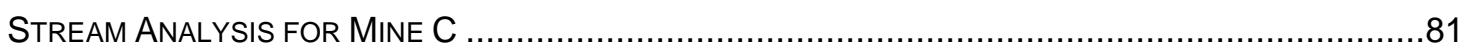

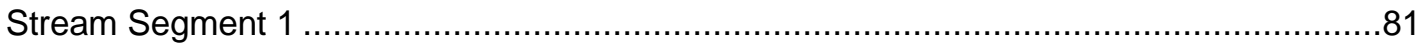

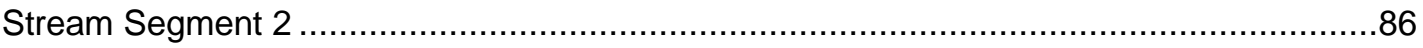

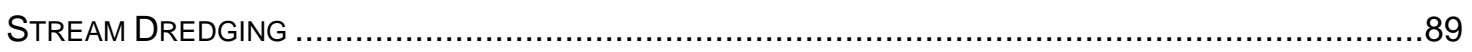

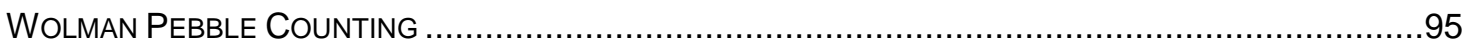

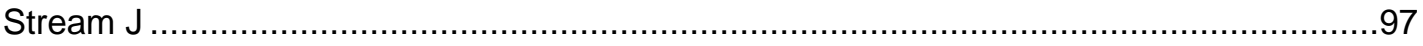

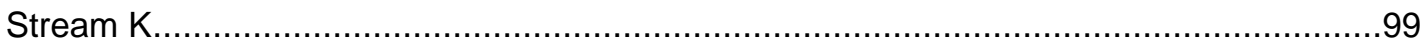

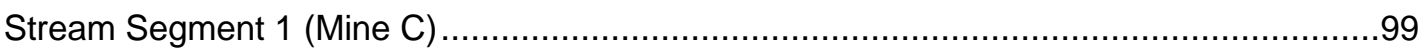

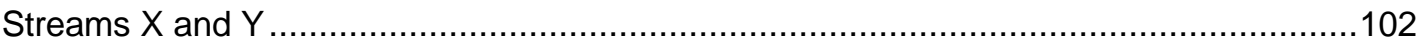

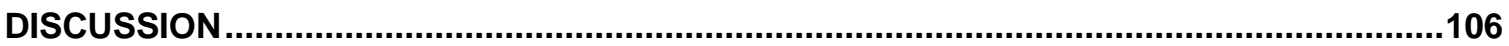

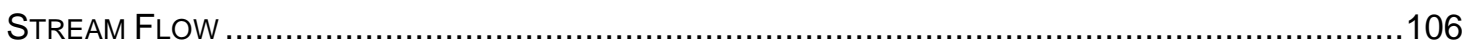

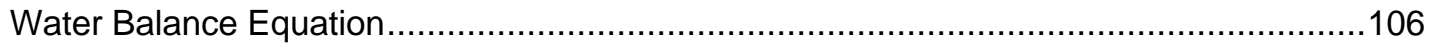

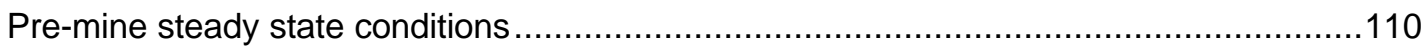

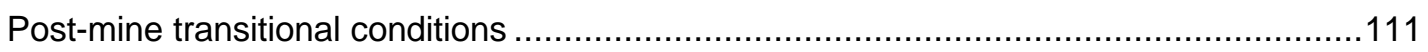

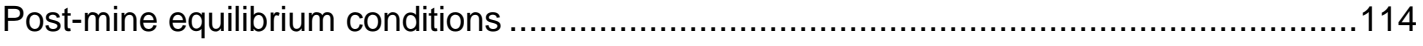

CONCLUSIONS.......................................................................................................116

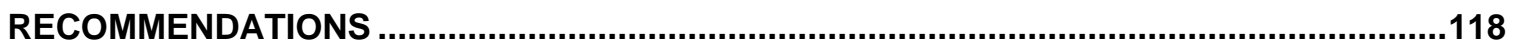

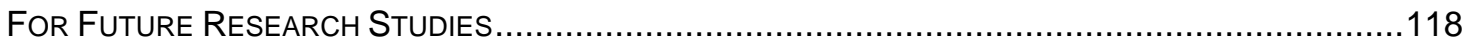

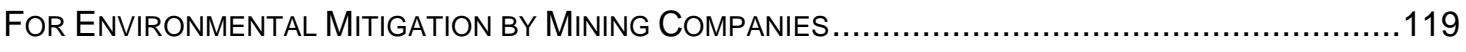

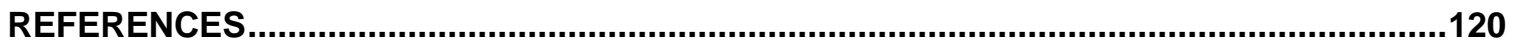

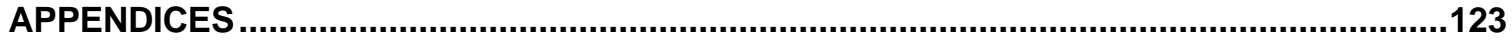

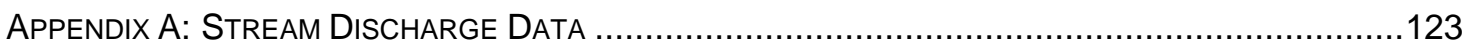

Appendix B: Temperature And Specific Conductivity Data ........................................129 


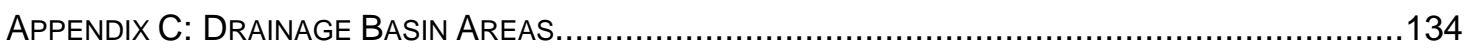

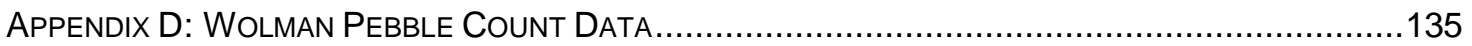

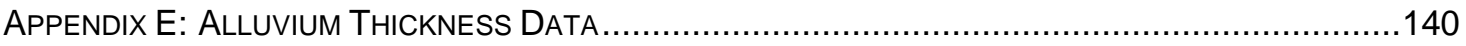

APPROVAL OF EXAMINING COMMITTEE ....................................................................141 


\section{TABLE OF FIGURES}

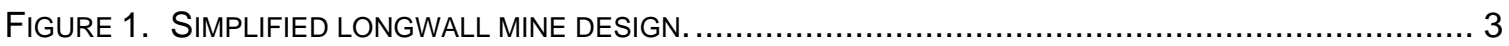

FIGURE 2. SCHEMATIC DEPICTION OF VERTICAL ZONES OF DISTURBANCE RESULTING FROM MINE SUBSIDENCE.

FIGURE 3. LOCATION OF ALL MONITORING STATIONS AND BASIN BOUNDARIES FOR THE STUDIED PORTION OF MINE Z.

FIGURE 4. LOCATION OF MONITORING STATIONS AND BASIN BOUNDARIES FOR STREAM SEGMENT1 AND 2 OVER THE STUDIED PORTION OF MINE C.

Figure 5. Simplified StRatigraphic COLUMn FOR THE ROCK UNITS AT MINE Z.

Figure 6. StRUCTURE CONTOUR MAP TO THE BASE OF THE PITTSBURGH COAL, SHOWING LOCATION OF CROSS SECTION LINES AT MINE Z

FIGURE 7. STRATIGRAPHIC CROSS-SECTION Z - Z', SHOWING STRATIGRAPHIC LOCATIONS FOR SOME STREAM MONITORING STATIONS AT MINE Z

FIGURE 8. STRATIGRAPHIC CROSS-SECTION Y -Y', SHOWING STRATIGRAPHIC LOCATIONS FOR SOME STREAM MONITORING STATIONS FOR STREAM SF AT MINE Z.

FIGURE 9. THREE-DIMENSIONAL VIEW OF A WEIR .22

Figure 10. CONSTRUCTION AND SIDE VIEW OF A WEIR. .23

FiguRE 11. PHOTOGRAPHS OF A WEIR INSTALLED IN THE FIELD.

FIGURE 12. STREAM CROSS-SECTION THAT HAS BEEN DIVIDED INTO SEGMENTS FOR THE MEASUREMENT OF STREAM DISCHARGE. .27

FIGURE 13. FOUR OF THE PRINCIPAL ENERGY COMPONENTS IN THE HEAT BALANCE OF SMALL STREAMS.

FIGURE 14. COMPONENTS OF A SURFACE STREAM HYDROGRAPH.

FIGURE 15. SCHEMATIC OF A DRAINAGE BASIN DIVIDED INTO SUB-BASINS, WITH TRIBUTARY AREA AND TRIBUTARY DISCHARGE SUBTRACTED FROM OVERALL MEASUREMENTS

FIGURE 16. SCHEMATIC OF A DRAINAGE BASIN DIVIDED INTO SUB-BASINS, DEFINED BY THE LOCATION OF MONITORING STATIONS. .36 
Figure 17. Plots of downstream distance along Steam Y at Mine Z Versus adjusted DISCHARGE: AREA RATIO, SPECIFIC CONDUCTIVITY, TEMPERATURE AND ALLUVIUM THICKNESS.....42

Figure 18. Plots of downstream distance along Stream X at Mine Z, Versus adjusted DISCHARGE: AREA RATIO, SPECIFIC CONDUCTIVITY, TEMPERATURE AND ALLUVIAL THICKNESS......44

Figure 19. Plots of downstream distance along Stream H at Mine Z Versus, adjusted DISCHARGE: AREA RATIO, TEMPERATURE, SPECIFIC CONDUCTANCE, AND ALLUVIAL THICKNESS....46

Figure 20. Plots of downstream distance along Stream G at Mine Z versus, adjusted DISCHARGE: AREA RATIO, TEMPERATURE, AND SPECIFIC CONDUCTANCE.

FIGURE 21. CLOSE-UP VIEW OF MONITORING STATIONS AND BASIN BOUNDARIES FOR STREAM K AT MINE Z.

Figure 22. Plots of downstream distance along Stream K at Mine Z Versus, adjusted DISCHARGE: AREA RATIO, TEMPERATURE, SPECIFIC CONDUCTANCE, AND ALLUVIAL THICKNESS....51

FIGURE 23. LOCATIONS OF ALL MONITORING POINTS ALONG StREAM SF AT Mine Z. .53

Figure 24. Plots of downstream distance along Stream SF versus, ADJusted discharge: AREA RATIO, TEMPERATURE, AND SPECIFIC CONDUCTANCE.

Figure 25. Plot of alluvial thickness for Stream SF at Mine $Z$.

Figure 26. Plot of downstream distance along Stream SF Versus, adjusted discharge: AREA RATIO, TEMPERATURE, AND SPECIFIC.

Figure 27. Plots of downstream distance along Stream SF Versus, adjusted discharge: AREA RATIO, TEMPERATURE, AND SPECIFIC.

Figure 28. Plot of downstream distance along Stream SF at Mine Z, versus all adjusted DISCHARGE:AREA RATIO DATA.

FIGURE 29. LOCATION OF ALL MONITORING STATIONS AND DRAINAGE BASIN BOUNDARIES FOR STREAM J AT MINE Z.

Figure 30. Plots of downstream distance for Stream J at Mine Z Versus, adjusted DISCHARGE: AREA RATIO, TEMPERATURE, AND SPECIFIC CONDUCTIVITY

Figure 31. Plots of downstream distance along Stream J at Mine Z Versus, adjusted DISCHARGE: AREA RATIO, TEMPERATURE, AND SPECIFIC CONDUCTIVITY. 
Figure 32. Plots of downstream distance along Stream J at Mine Z Versus, adjusted DISCHARGE: AREA RATIO, TEMPERATURE, AND SPECIFIC CONDUCTIVITY.

Figure 33. Alluvial thickness for Stream J at Mine Z.

Figure 34. Plots of downstream distance along Stream J at Mine Z Versus, adjusted DISCHARGE: AREA RATIO, TEMPERATURE, AND SPECIFIC CONDUCTIVITY.

Figure 35. Plots of downstream distance along Stream J at Mine Z versus, adjusted DISCHARGE: AREA RATIO, TEMPERATURE, AND SPECIFIC CONDUCTIVITY.

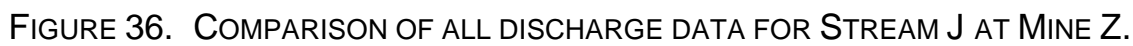

Figure 37. Plots of downstream distance along Stream Segment 1 at Mine C versus, ADJUSTED DISCHARGE: AREA RATIO, TEMPERATURE, AND SPECIFIC CONDUCTIVITY

Figure 38. Plot of the alluvial thickness for Stream Segment 1 at Mine C

Figure 39. Photographs of Stream Segment 1 at Mine C.

Figure 40. Plots of downstream distance along Stream Segment 2 at Mine C versus, ADJUSTED DISCHARGE: AREA RATIO, TEMPERATURE, AND SPECIFIC CONDUCTIVITY.

FIGURE 41. SCHEMATIC SHOWING A STREAM AND LAND SURFACE PREVIOUS TO LONGWALL MINING IMPACTS; AFTER MINING IMPACTS; AND AFTER STREAM DREDGING.

Figure 42. PhOtographS SHOWING STREAM DREDGING ALONG TWO STREAMS IN THE VICINITY OF MINE Z.

FIGURE 43. EXCAVATION SURVEY MARKERS FOR STREAM DREDGING ALONG STREAM SF

Figure 44. Profile lines for the stream bottom along Stream SF at Mine Z. .94

Figure 45. Wolman PEBBLE COUNT RESULtS For StREAM J AT Mine Z....... .98

Figure 46. Wolman PEBble COUNT RESUlts FOR Stream K AT Mine Z. 100

Figure 47. Wolman pebble Count Results for Stream Segment 1 at Mine C. 101

FIGURE 48. Wolman PEBBLE COUNT RESULTS FOR StREAM Y AT Mine Z 103

Figure 49. Wolman PEBble COUNT RESUlts For Stream X AT Mine Z. 104

FIGURE 50. A BASIC CONCEPTUAL SCHEMATIC OF A WATERSHED WHICH SHOWS THE NECESSARY COMPONENTS OF THE REGIONAL WATER BALANCE. 
FIGURE 51. SCHEMATIC DIAGRAM OF PRE-MINE, POST-MINE TRANSITIONAL, AND POST-MINE EQUILIBRIUM

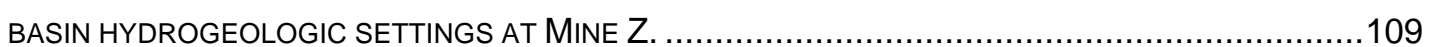




\section{LIST OF TABLES}

Table 1. Measurement eVents for streams at both Mine Z and Mine C ...............................40

TABLE 2. AlLUVIUM SizE AND THICKNESS DATA FOR IMPACTED AND NON-IMPACTED STREAMS AT BOTH

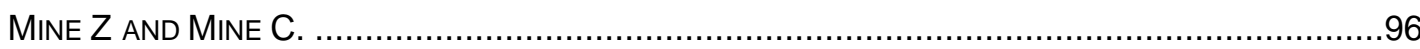

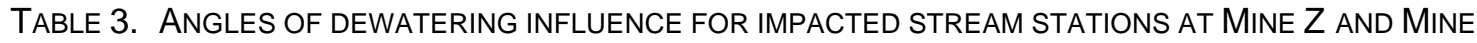
C, WITH RESPECT TO NEAREST DOWNSTREAM PANEL. 


\section{INTRODUCTION}

\section{Background}

Coal mining has been a major part of the economy of West Virginia and the northern Appalachian Coal Basin for many years. Longwall mining was first introduced into the region in the 1970's (Peng and Chiang, 1984). In 1981, longwall mining reached a maximum in the U.S. with 118 active faces producing over 50 million tons of coal. In 1995, 80 longwall panels were operated, with West Virginia leading all states (Parizek and Ramani, 1995). Longwall mining is preferred over room and pillar mining because it yields $30 \%$ more coal $(75 \%$ to $90 \%$ coal recovery), is safer, and has more predictable and controlled subsidence (Coe and Stowe, 1984).

Unfortunately, longwall mining has been shown to have negative impacts on ground and surface waters (Cifelli, 1986; Tieman, 1986; Dixon, 1988; Carver, 1994; Reed, 1998; Cifelli and Rauch, 1986; Tieman and Rauch, 1987; Dixon and Rauch, 1988; Dixon and Rauch, 1990; Carver and Rauch, 1994). Ground subsidence produced by longwall mining may cause partial or total loss of surface water, well water, and naturally occurring springs. These negative impacts may cause major socioeconomic repercussions.

\section{Purpose}

The purpose of this study is to gain better understanding of how underground longwall coal mining, mine subsidence, and interacting geologic 
variables impact baseflow discharge of streams in northern West Virginia, primarily at Mine Z. From these impacts, improved understanding of stream dewatering and degree of subsequent recovery following mining should be gained. This understanding may allow recommendations to be made for stream grouting, stream dredging, or other remediation methods, if appropriate. Results of this study may be of interest to private landowners, regulatory agencies, and the coal industry.

\section{LITERATURE REVIEW}

\section{Longwall Mining and Mine-Subsidence Theory}

An understanding of longwall mining is required to comprehend the impacts of longwall mining on the hydrology of an area. According to Peng and Chiang (1984), longwall mining is used mainly in Appalachian coalfields where nearly all coal beds are horizontal or nearly horizontal. Longwall mining allows a large portion of a coal bed to be extracted as a single slice. This mining technique involves removal of large blocks of coal, beginning with development

pillars and moving toward the main entries (Peng and Chiang, 1984) (Figure 1). Panel width, W, generally varies from 300 to 1200 feet (90-210 meters). Panel length, L, generally ranges from 2000 to 8000 feet (600-2400 meters). Trends are toward wider and longer panels (Peng and Chiang, 1984).

As coal is removed, a void is left, with little or no structural support of the ceiling weight. The void is filled by collapse of overburden bedrock. The overlying rock continues to collapse, generally extending upward two 


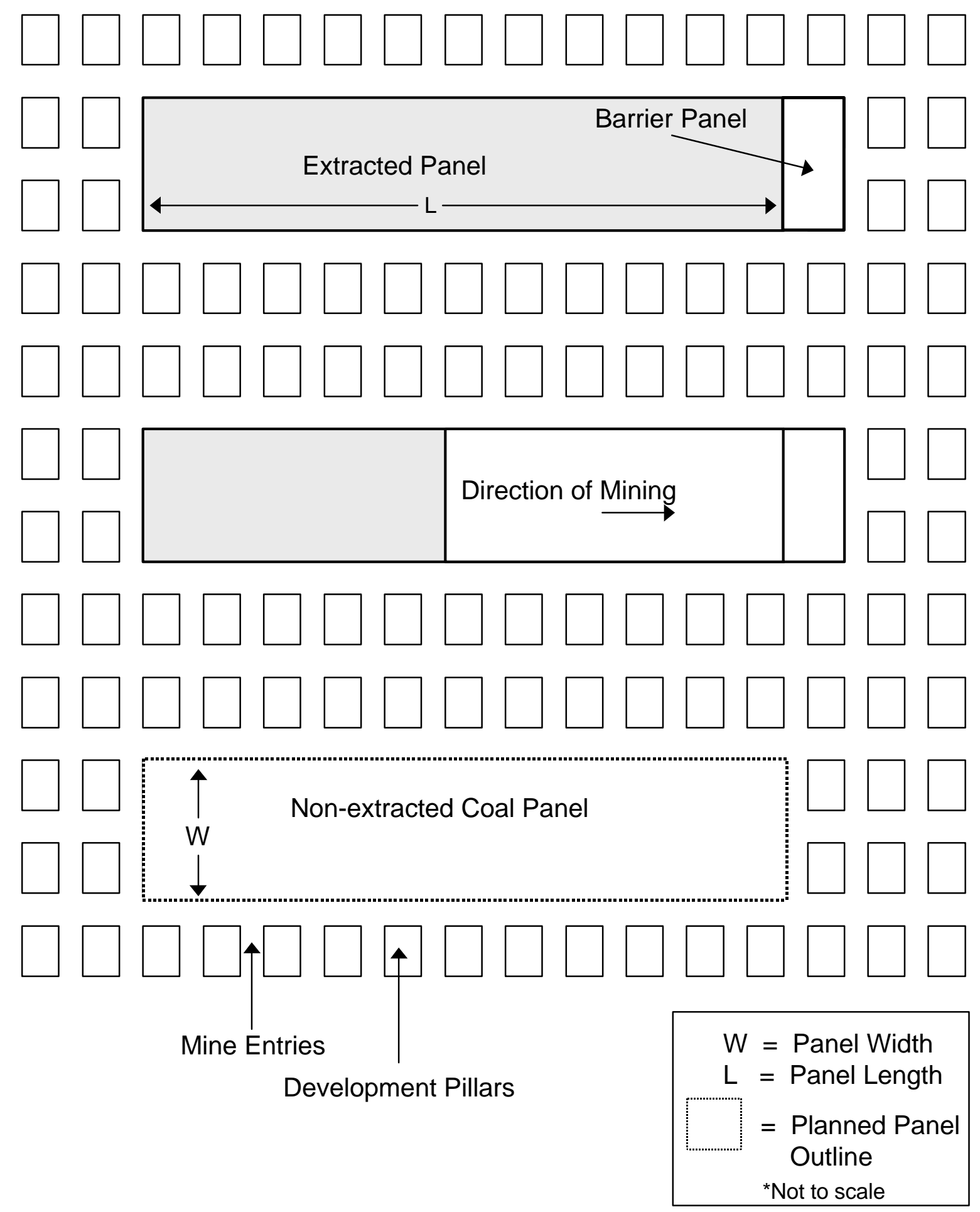

Figure 1. Simplified longwall mine design (from Carver, 1994, which was modified from Peng and Chiang, 1984). 
to eight times the thickness of the mined coal seam, referred to as the caved zone (Coe and Stowe, 1984)(Figure 2). The remaining overlying uncaved overburden, partially supported by collapsed overburden, is highly fractured. The fractures in this zone predominately occur along natural joint systems, rather than breaking into discrete blocks. This highly fractured zone can be subdivided into two zones. The lower fracture zone continues upward from the caved zone approximately 24 to 54 times the thickness of the original coal seam (Coe and Stowe, 1984). The aquiclude zone (now better termed the confining layer zone) sits atop the lower fracture zone and continues upward to within a few 10's of feet of the ground surface. The rock strata in this zone are under lateral compression, which preserves the original vertical permeability along joints. The aquiclude zone thickness depends upon overburden depth, and may be totally absent for mine depths less than 300 to 400 feet, depending on overburden rock lithology (Rauch, 1989).

Sagging of the ground surface typically results as subsidence continues upward. Sagging takes the shape of a trough and is accompanied by exterior tensional zones and interior compressional zones, which commonly cause surface fractures (Coe and Stowe, 1984). The uppermost zone in Figure 2 is called the continuous deformation zone, or the surface fracture zone. Minimal surface fracturing is expected where the removed coal is so deep that subsidence has little effect on the surface. 


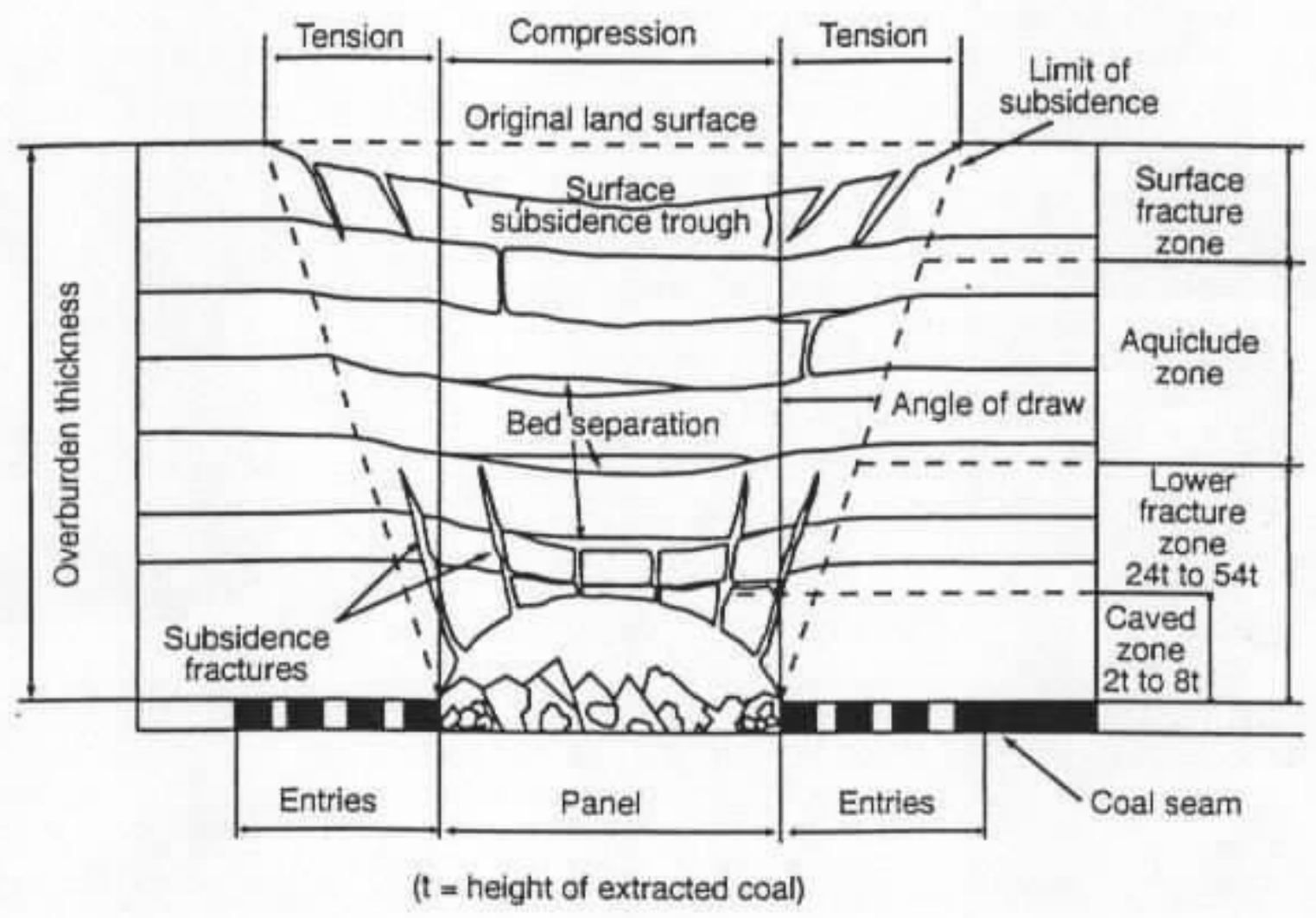

Figure 2. Schematic depiction of vertical zones of disturbance resulting from mine subsidence (from Carver, 1994, which was modified from Ground Water Associates, 1984). There is vertical exaggeration and distortion in this figure. 


\section{Effects of Mining on Ground Water and Streamflow Outside the Study Area}

Many studies have shown that ground water systems have been affected by undermining and mining subsidence (Dixon, 1988; Cifelli, 1986; Tieman, 1986; Rauch, 1989; Cifelli and Rauch, 1986; Tieman and Rauch, 1987; Dixon and Rauch, 1988). Aquifers with a relatively thin overburden zone (up to 280 feet thick) can dewater almost completely, in some situations. Conversely, areas of relatively thick overburden (approximately 585-900 feet) may see little or no impact on water supplies (Dixon and Rauch, 1988).

Tieman (1986) and Tieman and Rauch (1987) looked at how longwall mine extraction of the Pittsburgh Coal affected dewatering at Mine $Y$ in southern Pennsylvania. The water supplies that were studied were selected based on their horizontal distance from the nearest underground mine. At Mine $\mathrm{Y}, 8$ of 11 supplies above longwall panels were partially or completely dewatered, with more extensive dewatering occurring above the centers of the longwall panels. Supplies located next to the longwall panels showed partial or complete dewatering in 11 of 16 supplies with an angle of dewatering influence of $42^{\circ}$ from vertical. Water supplies located outside the $42^{\circ}$ angle of dewatering influence showed no dewatering (Tieman, 1986).

A stream dewatering study by Reed (1998) involved the heavily undermined Spruce Laurel Fork in Boone County, West Virginia. Reed discovered that dewatering occurred in isolated reaches of the stream, but in other reaches, the stream was gaining discharge from elevated mine pools. Studies have shown that stream discharge can be positively or negatively 
influenced over subsided underground mines (Bowers, 1979; Dixon, 1988; Cifelli, 1986; Tieman, 1986; Reed, 1998; Rauch, 1989; Cifelli and Rauch, 1986; Tieman and Rauch, 1987; Dixon and Rauch, 1990).

Bowers (1979) studied the impacts of underground mining on Scotts Run in northern West Virginia. The Pittsburgh and Sewickley coals under Scotts Run were completely mined out beneath the study area by the early 1970's (Bowers, 1979). Results indicate that there was significant water loss from streams and aquifers due to coal mining. The downstream half of Scotts Run, where the uppermost underground mined coal bed was commonly less than 100 feet deep, was losing more water to deep mines and related fractures than it was gaining from aquifers during low flow (Bowers, 1979). The upstream half of Scotts Run was gaining only slightly more water at low flow from its aquifers than it was losing to deep mines and related fractures (Bowers, 1979).

\section{Previous Research at Mine Z}

Tieman (1986) and Carver (1994) studied portions of Mine Z, an active longwall mine located in northern West Virginia, to better understand the dewatering effects of longwall mining. Mine $Z$ was also used for this study.

Tieman found that Mine Z, a longwall mine in the Pittsburgh coal, showed some negative effects on ground water from undermining. Five of 12 water supplies located over longwall panels were partially or completely dewatered. An angle of dewatering influence could not be determined because some ground water supplies and streams adjacent to longwall mines showed no dewatering at 
all (Tieman, 1986; Tieman and Rauch, 1987; Tieman, et al., 1992). Tieman also concluded stream dewatering was common adjacent to or above mined longwall panels that were less than one to two years old (since mining occurred), but normal streamflows occurred over older mined panels (Tieman, 1986).

Carver (1994), at Mine Z, concluded that topographic positions of a well influenced the degree and duration of subsidence-induced impacts. Wells located in lower hillslopes and valleys experienced short-term dewatering (days to weeks), but 73 percent of wells located on hillslopes or hilltops experienced total dewatering (Carver, 1994; Carver and Rauch, 1994).

A later study of the hydrogeologic effects of subsidence at Mine Z suggested that subsidence from longwall mining typically reduced or eliminated stream discharge for two to three years following mine subsidence. The degree and duration of the dewatering effects were dependent on the position of a longwall panel beneath a basin (Carver, 1994). Carver also determined that, in some cases, the magnitude of the angle of dewatering influence was inversely proportional to stream discharge.

\section{Previous Research at Mine C}

Mine C, an inactive longwall mine in northern West Virginia, was studied by Dixon (1988), and was used for this study. Dixon (1988) measured discharge for three streams in the vicinity of Mine C. Dixon discovered a dewatering trend for Stream 2, segment 1. Instead of stream discharge decreasing over longwall panels, the opposite occurred, with the decrease occurring over the underlying 
room-and-pillar mine portions between two adjacent panels. The decrease in discharge from the vertical center of a projected panel to the center of the adjacent room-and-pillar mined section was contributed by a lack of additional ground water runoff being introduced to the stream. This was also coupled with a temporary loss of streamflow to the upper part of the fracture zone under this stream (Dixon, 1988). Dixon also concluded that, at areas where water was lost because of surface subsidence fractures, it was unlikely that water leaked directly into the mine because of the great mine overburden thickness (about 500-600 feet). Lost water probably was residing in an upper fracture zone created by subsidence above protective confining (shale) layers (Dixon, 1988). 


\section{OBJECTIVES}

In general, the purpose of this study is to better understand the effects that longwall mining has on surface water systems. The specific goals and objectives of this research are as follows:

1) Determine the extent and degree of the impact that underground mine subsidence has on overall water quantity in the selected streams.

2) Determine trends in streamflow loss by investigating mine subsidence theory, mine setting, (orientation, width, and location of longwall panels relative to streams), and hydrogeologic setting for the watershed.

3) Develop a conceptual model for the causes of stream dewatering.

4) Determine the effects of time since undermining and stream dredging repairs occurred on streamflow recovery for subsidence impacted streams.

5) Make recommendations for more effective management of undermined streams. 


\section{STUDY AREA}

The studied area is located in northern West Virginia (Figure 3). This area was chosen because of the abundance of longwall mining and availability of information from the primary coal company. In exchange for this information, it was agreed that the company name and specific location of the study area remain confidential. This area was previously studied by Tieman (1986) and Carver (1994), and is referred to as Mine Z.

Mine C, previously studied by Dixon (1988), is also located in northern West Virginia (Figure 4). This mined area was selected for study because of its close proximity to Mine Z. Similar geographic, geologic, and mining setting conditions occur at both Mine $\mathrm{C}$ and Mine Z.

\section{Geography}

The terrain of the studied areas is typical of the Appalachian Plateaus physiographic province, which is characterized by deep incised stream channels and a highly dendritic drainage pattern. Farms or residential lots occupy most of the land. The larger streams in this area flow to the east and empty into the Monongahela River.

\section{Geology}

Late Paleozoic Dunkard and Monongahela groups overlie Mine Z (Figure 5). Two structural folds occur in this area: the Waynesburg syncline to the west and the Mooresville anticline to the east (Carver, 1994).

The Dunkard series is the uppermost division of the Paleozoic system of rocks in the Appalachian Region of North America, and the most recent bedrock 


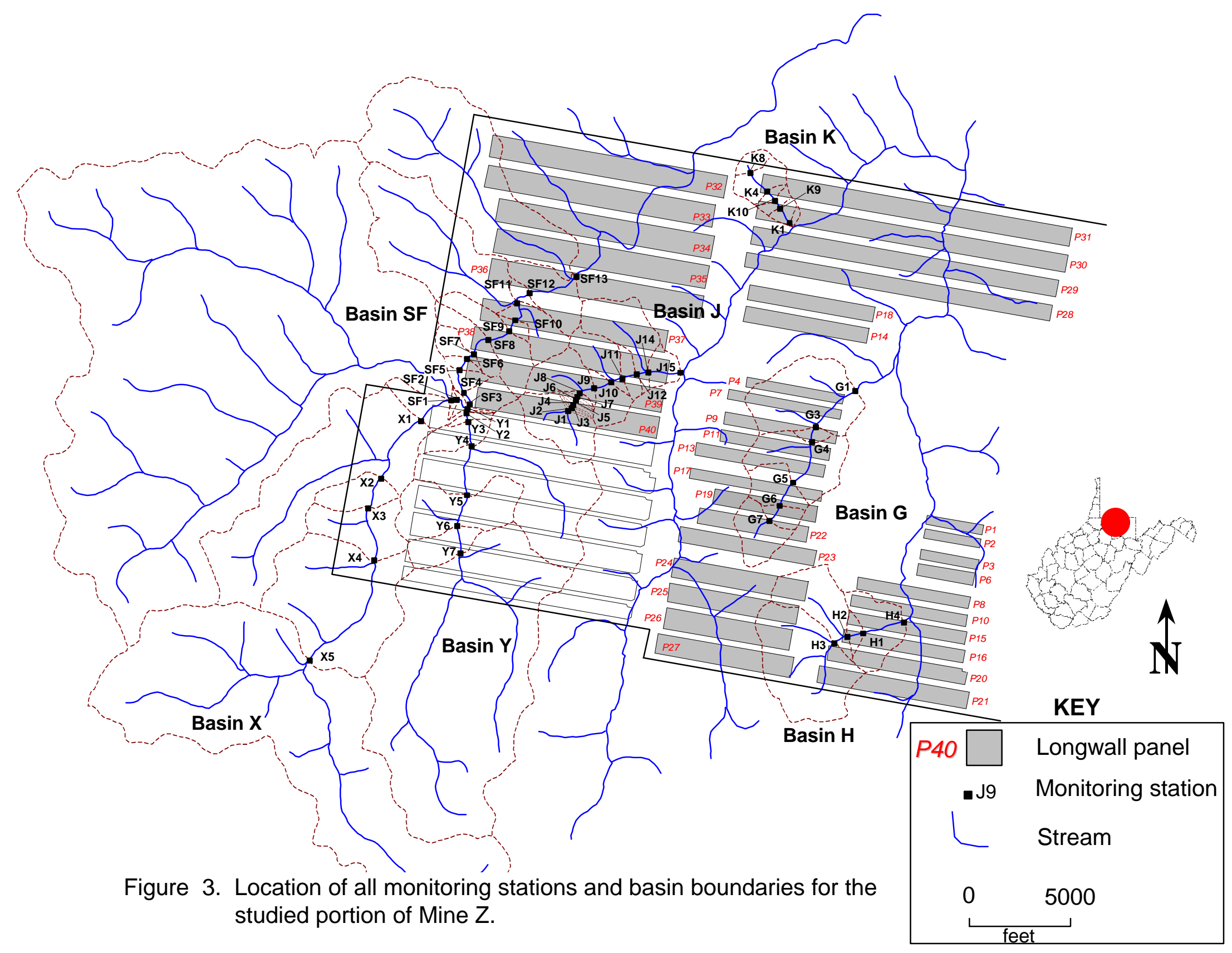




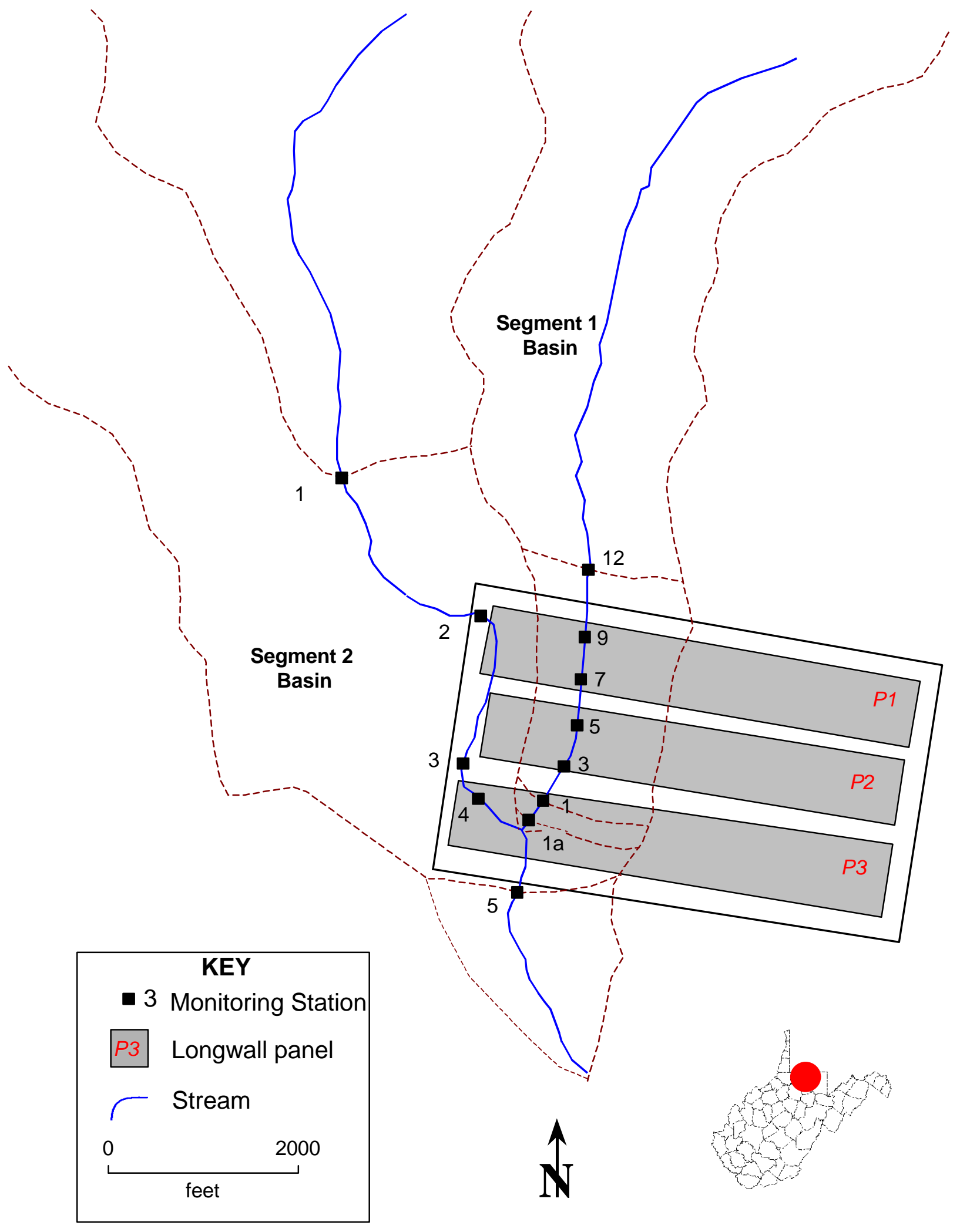

Figure 4. Location of monitoring stations and basin boundaries for Stream Segments 1 and 2 over the studied portion of Mine C. 


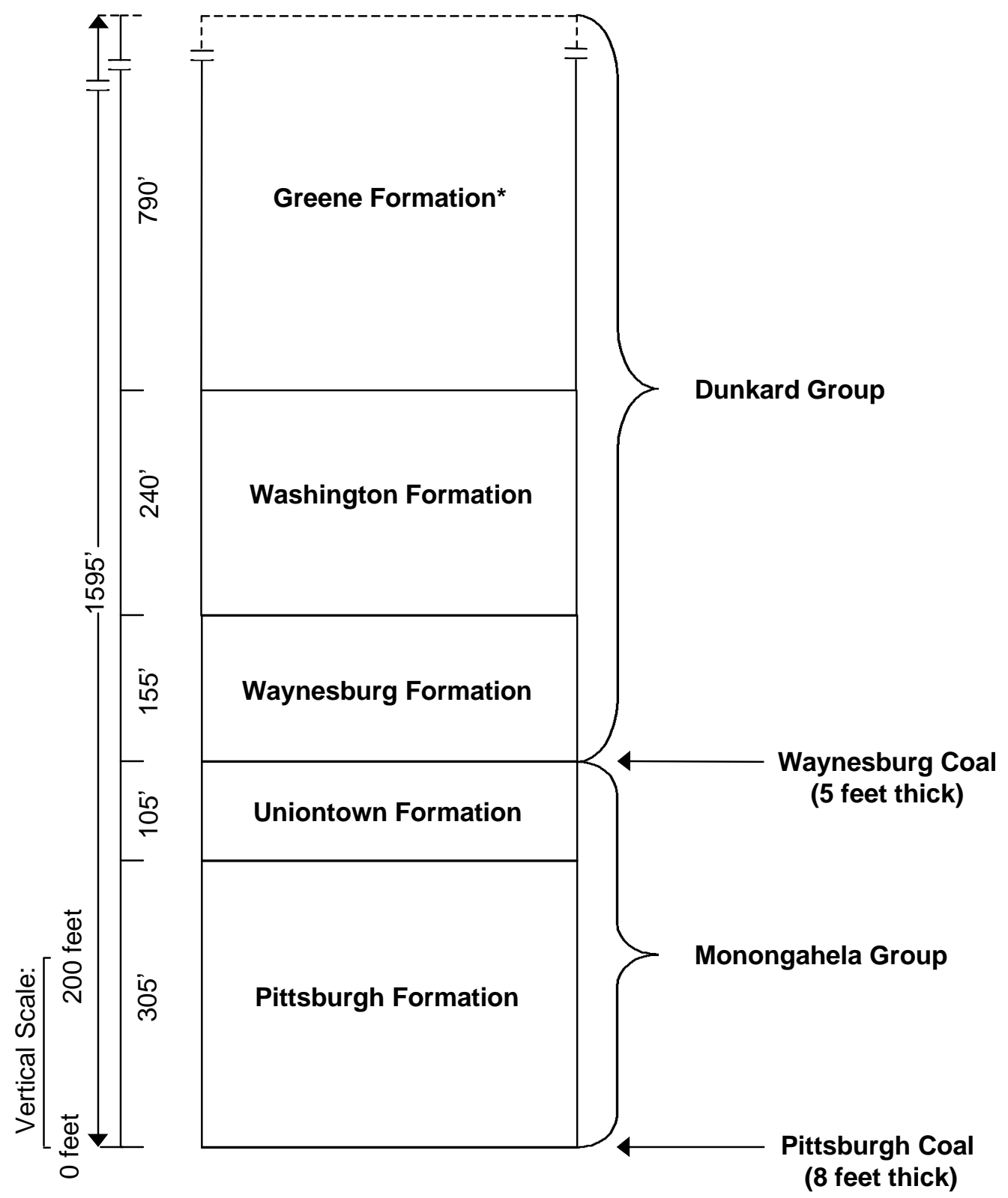

Figure 5. Simplified stratigraphic column for the rock units at Mine Z. The Greene Formation totals 790 feet in thickness, but the entire section of this formation is not represented in this study area. 
formation in the Monongalia-Marion-Taylor County area (Hennen and Reger, 1913). The Dunkard Series consists of the Greene, Washington, and Waynesburg formations, with the Greene and Washington formations exposed at the surface in the study area (Carver, 1994). The Greene Formation, approximately 790 feet thick, is made up of mostly shale, sandstone, limestone, clay, and fireclay. The underlying Washington Formation, 240 feet thick, consists mostly of sandstone and shale, with the Washington Coal as its basal member. The Waynesburg Formation consists of many thin limestone, coal, shale, and sandstone beds, with two 45 feet thick, sandstone beds (Mannington and Waynesburg sandstones).

The Pennsylvanian Monongahela Series consists of the Uniontown and Pittsburgh formations. The Uniontown consists mostly of two large sandstone units (Gilboy and Uniontown), each approximately 35 feet thick, three shale units, and a thin-bedded limestone. The total thickness of the Uniontown Formation is approximately 105 feet (Hennen and Reger, 1913). The Pittsburgh Formation is almost three times thicker than the Uniontown, approximately 305 feet, and also contains more limestone beds. The Pittsburgh consists of four sandstone units (Arnoldsburg, Sewickley, Lower Sewickley, and Upper Pittsburgh), four limestone units (Uniontown, Benwood, Sewickley, and Redstone), three shale units, and two significant coal beds (Sewickley and Redstone). The Pittsburgh Coal measures approximately 8 feet in thickness and is the basal member of the formation. 
A structure contour map for the elevation of the bottom of the Pittsburgh Coal (Figure 6) shows the Pittsburgh Coal becomes deeper to the west. This map was crucial in determining Mine $Z$ overburden thickness to the streams.

Fence diagrams were constructed to show the geologic structure for selected areas of Mine Z (Figures 7 and 8). Streamflow monitoring stations were plotted on the fence diagrams in order to recognize any possible relationship between underlying bedrock geology and streamloss. Other stream stations at Mine $Z$ are plotted on fence diagrams completed by Carver (1994), located along lines $A-A^{\prime}$ and $B-B^{\prime}$ on Figure 3 and can be found in Carver's thesis (pp.137139). 


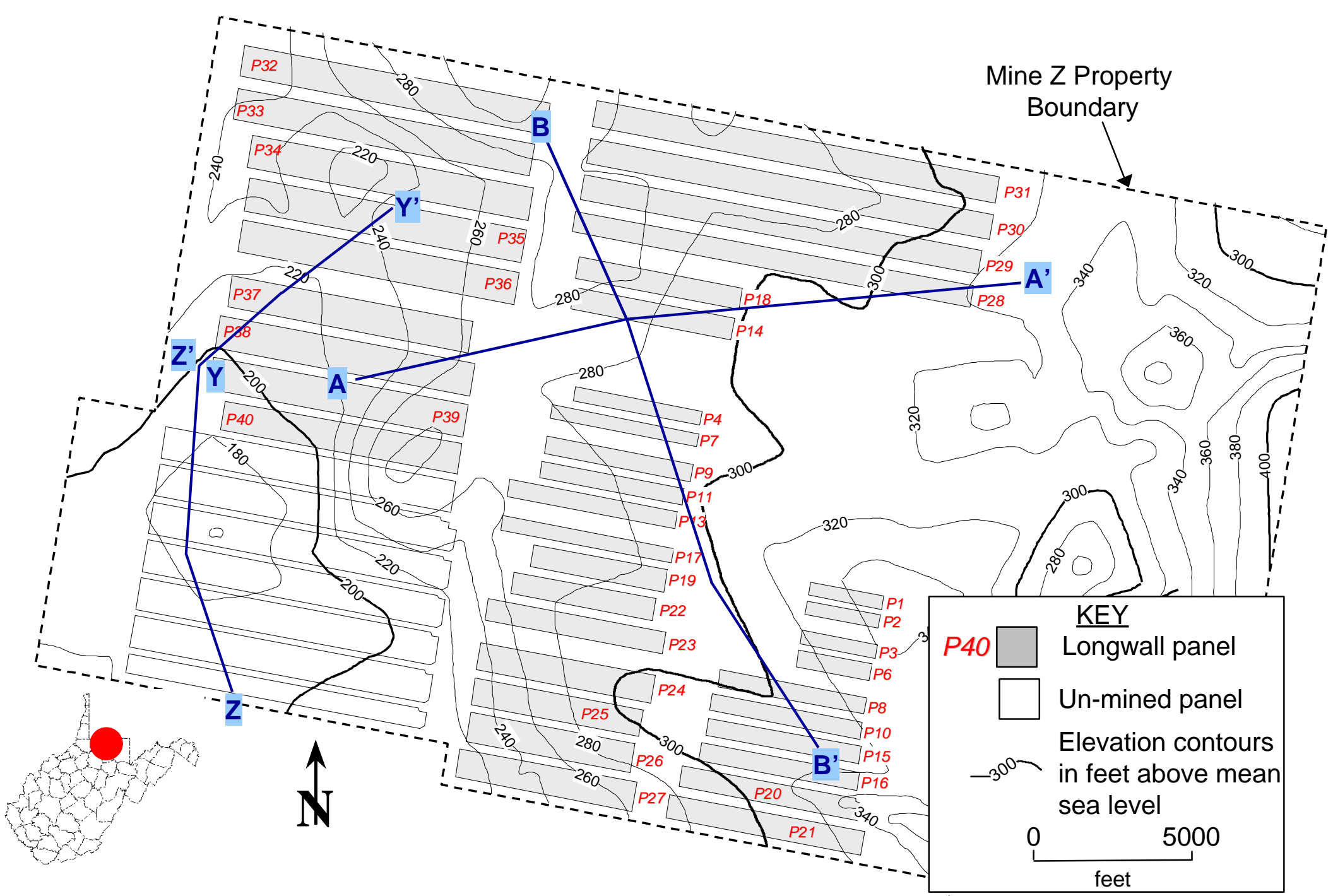

Figure 6. Structure contour map to the base of the Pittsburgh Coal, showing location of cross section lines at Mine Z. 


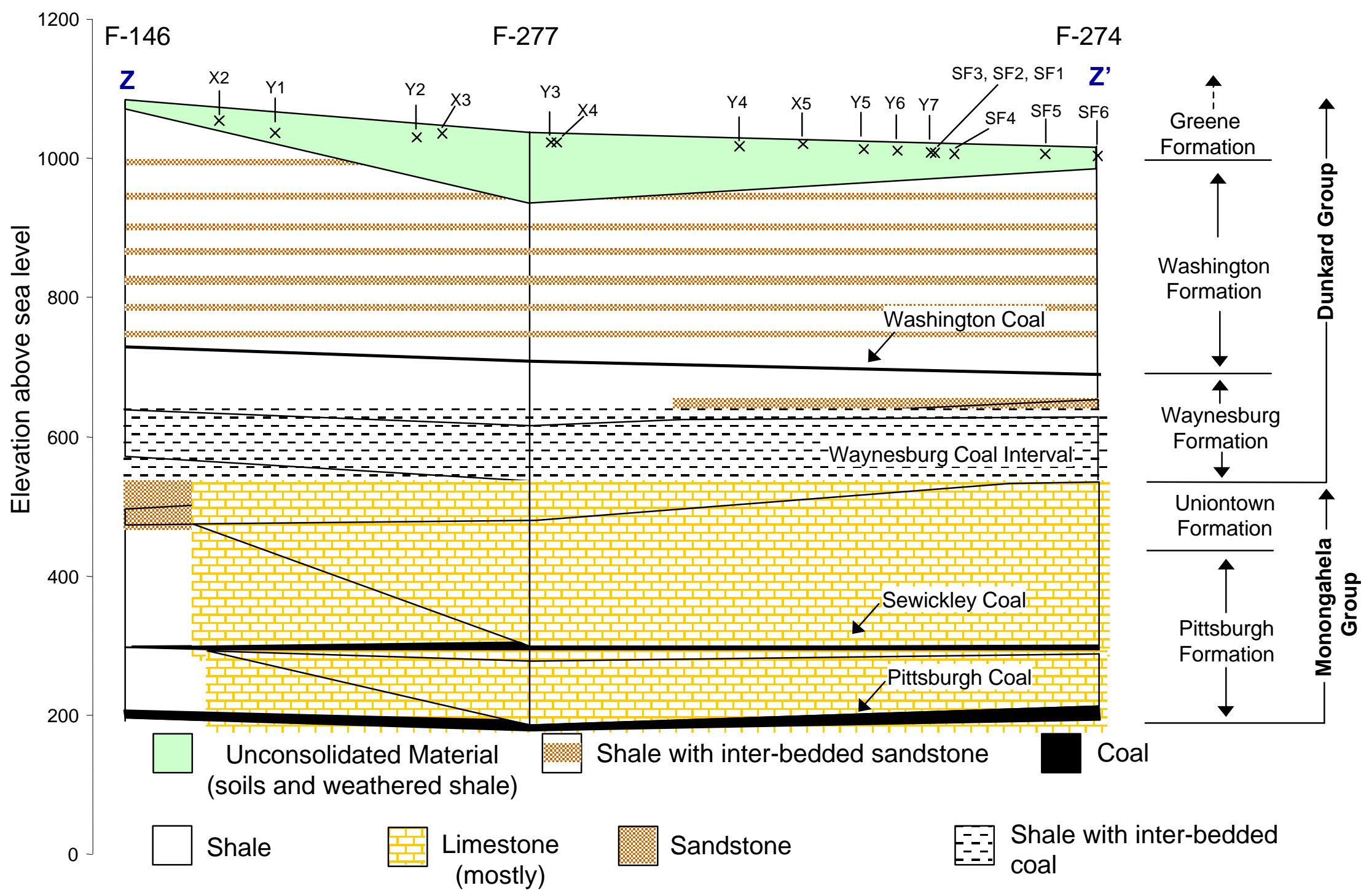

Figure 7. Stratigraphic cross-section Z - Z', showing stratigraphic locations for some stream monitoring stations at Mine $Z$. 


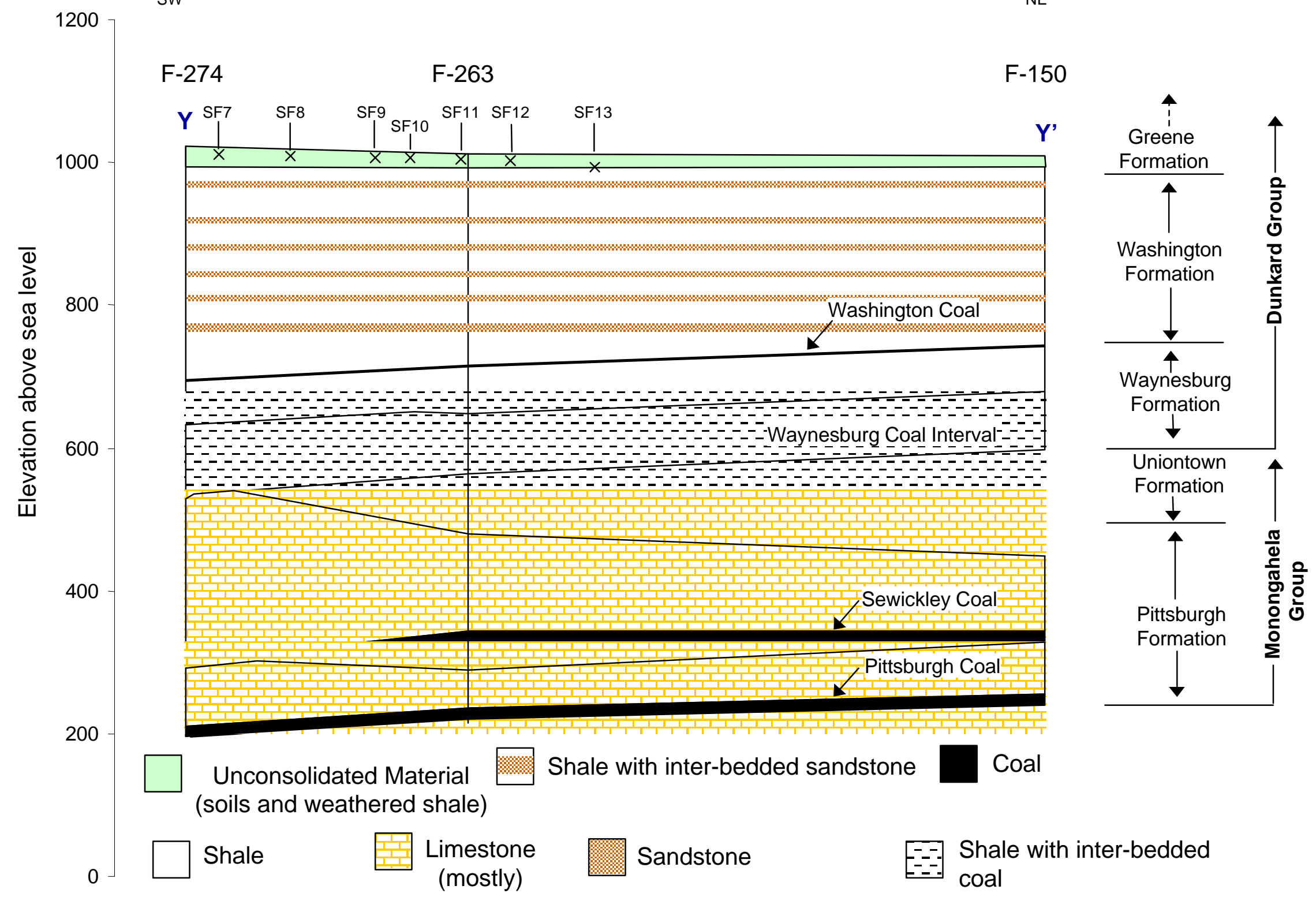

Figure 8. Stratigraphic cross-section $\mathrm{Y}-\mathrm{Y}^{\prime}$, showing stratigraphic locations for some stream monitoring stations for Stream SF at Mine Z. 


\section{METHODS OF INVESTIGATION}

\section{Selection of Streams for Study}

Streams were selected for study based on factors such as stream orientation, stream width, location of longwall panels relative to streams, past research in the study area (Carver, 1994), and discussions with the coal company that owns Mine Z. Carver (1994) previously studied some streams included in this study, whereas other streams in this area have been undermined since his study. A stream planned for future undermining was studied to allow base-line measurement of streamflow in anticipation of future studies.

Stream discharge was measured from near the headwaters to the mouths, with about 8 to 10 measuring stations for each stream. Both mine maps (supplied by the coal company for Mine Z) and U.S. Geological Survey 7.5-minute topographic maps were cross-referenced in order to select positions for the stream-discharge monitoring stations. Measurement stations were located approximately 100 to 1000 feet apart, taking into account the positions of longwall panels. Discharge on tributaries to these streams was also measured. Measurements were taken for control streams not overlying undermined areas in order to compare their results to those of the undermined streams. Staked positions were established at each station to allow repeat visits. 


\section{Collection of Field Data}

\section{Stream Discharge}

\section{Weir Method}

Plywood and metal weirs were constructed and placed in the stream where the channel was shallow and narrow in order to measure stream discharge. A weir is a vertical baffle that restricts the total flow of water in an opened or closed channel. Weirs are the simplest devices used to measure flow (Driscoll, 1986)(Figure 9). Portable $90^{\circ} \mathrm{V}$-notch weirs were used for applications at nine stations along Stream J. Originally, weirs were planned for more streams, but unsuitable conditions (wide and deep channels) limited their use. Weirs were installed by digging small vertical cuts, or slits, in the stream bank, perpendicular to the direction of stream flow. A small linear trench was dug into the streambed, also perpendicular to stream flow. The weir was forced into the slits and streambed with the aid of a hammer. After each weir was installed, it enabled all streamflow to be diverted through the $\mathrm{V}$-notch with a pool extending some distance upstream, called the weir pond. The water that passed through the notch and over the V-notch is referred to as the nappe (U.S. Department of the Interior, Bureau of Reclamation, 1953).

The weirs were constructed of $3 / 4$ inch thick treated plywood and the $90^{\circ} \mathrm{V}$ notch was constructed of steel so that the notch was sharp-edged to allowed water to "spring free" at low discharge (Dingman, 1994)(Figure 10). The metal lined side of the V-notch faced upstream. All of the weirs were constructed to a standard dimension of 6 feet long by 2 feet wide with the bottom of the V-notch 


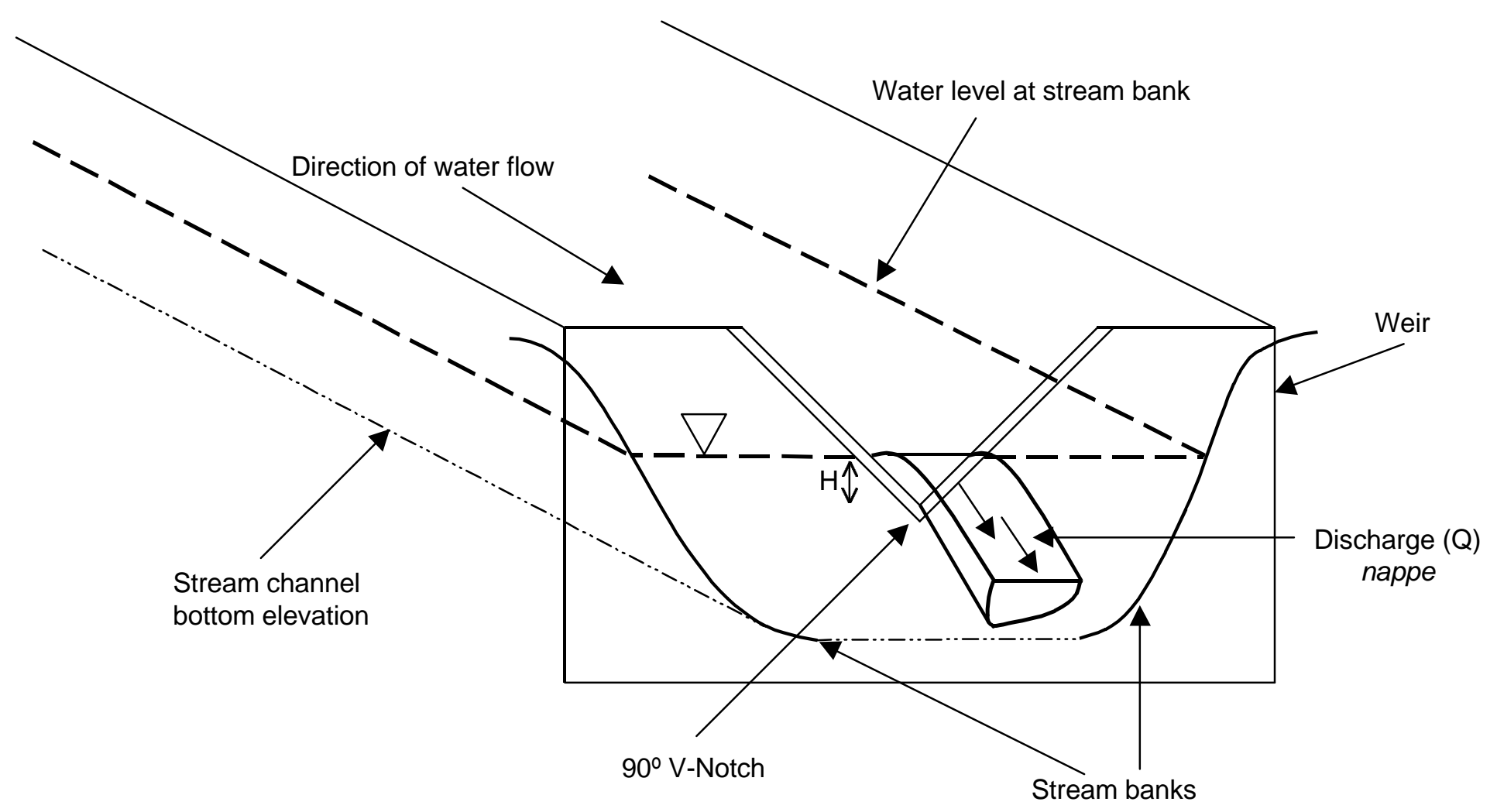

Figure 9. Three dimensional view of a weir. V-notch weirs are placed in the streambed,confining all streamflow through the $\mathrm{V}$-notch. Discharge is determined from its mathematical relationship to the height of the flow $(\mathrm{H})$ through the notch. 

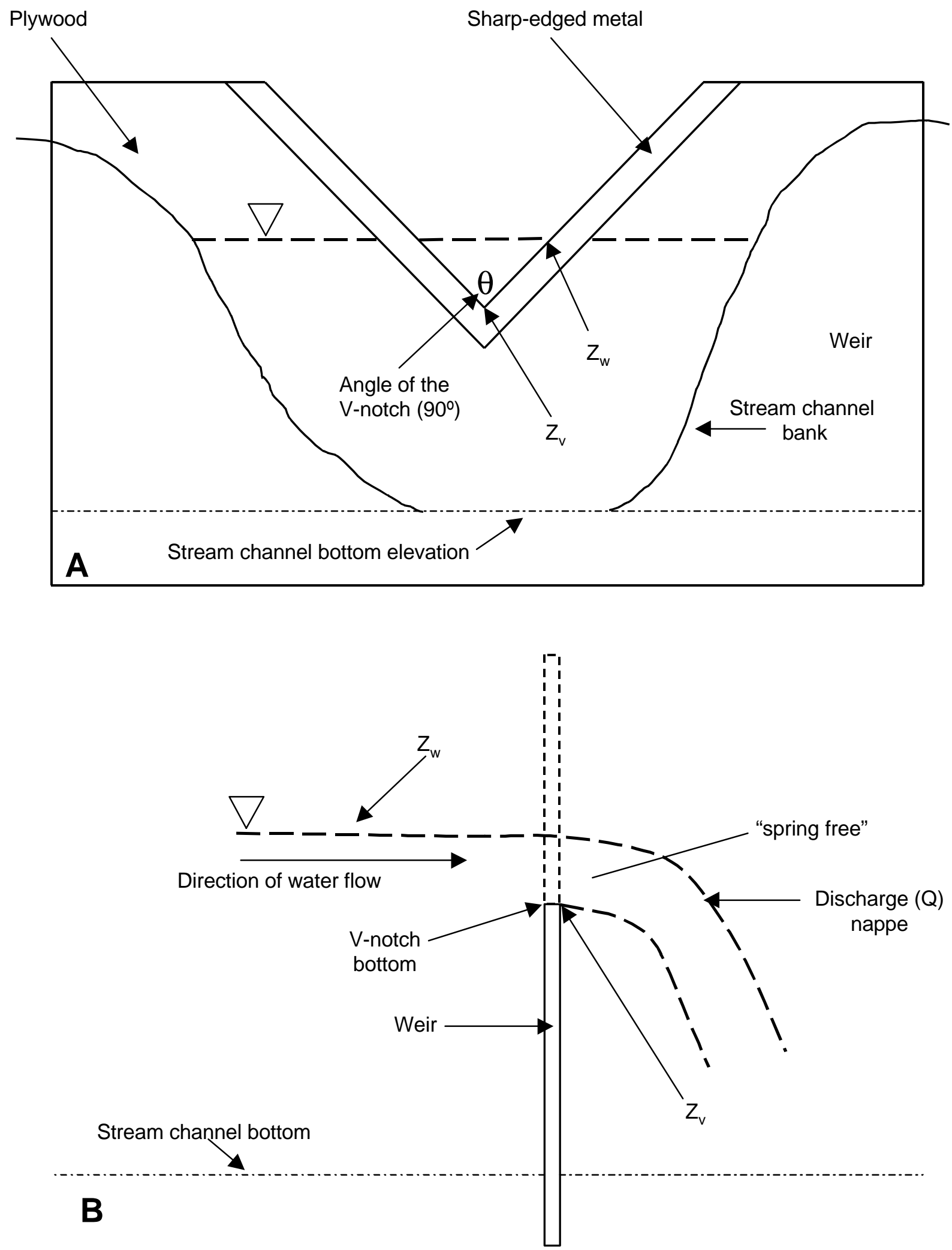

Figure 10. Figure $10 \mathrm{~A}$ shows the construction of a weir plate. Figure 10B displays the side view of flow through $\mathrm{V}$-notch weir. 
located 1 -foot from the bottom of the weir (Figure 10). Some of the weirs needed to be custom fit at individual stations because of varied stream width and depth. These weirs were cut with a handsaw in order to alter the outside dimensions of the weir. Figure 11 shows photos of an installed weir in the field.

Drawdown, or the downward curving of the surface water as it passes over the $\mathrm{V}$-notch bottom point (at elevation $\mathrm{Z}_{\mathrm{v}}$ ), extends upstream a short distance from the weir notch. The water level, or head (at elevation $Z_{w}$ ), must be measured at a point on the water surface of the weir pond that is beyond (upstream of) the effect of the drawdown (U.S. Department of Interior, Bureau of Reclamation, 1953). Discharge through a weir is determined by measuring the $Z_{w}$ head elevation above the $Z_{v}$ bottom point of the $V$-notch, and relating that elevation to discharge (Dingman, 1994). The following equation was used to measure discharge (Dingman, 1994):

$$
Q=C_{w} g^{1 / 2} \tan \left(\theta_{w} / 2\right)\left(Z_{w}-Z_{v}\right)^{5 / 2}
$$

where: $\quad Q=$ stream discharge

$Z_{w}=$ elevation of the pooled water surface

$Z_{v}=$ bottom point elevation of the $V$-notch

$g$ = gravitational acceleration constant

$\theta_{\mathrm{w}}=$ the angle of the $\mathrm{V}$-notch

$\mathrm{C}_{\mathrm{w}}=0.43$ (weir coefficient)

which reduces to (Fetter, 1994):

$$
\mathrm{Q}=2.5 \mathrm{H}^{5 / 2}
$$

where: $\quad H=$ the head of the backwater above the weir crest $\left(Z_{w}-Z_{v}\right)$

* assuming the angle of the V-notch is $90^{\circ}$ 

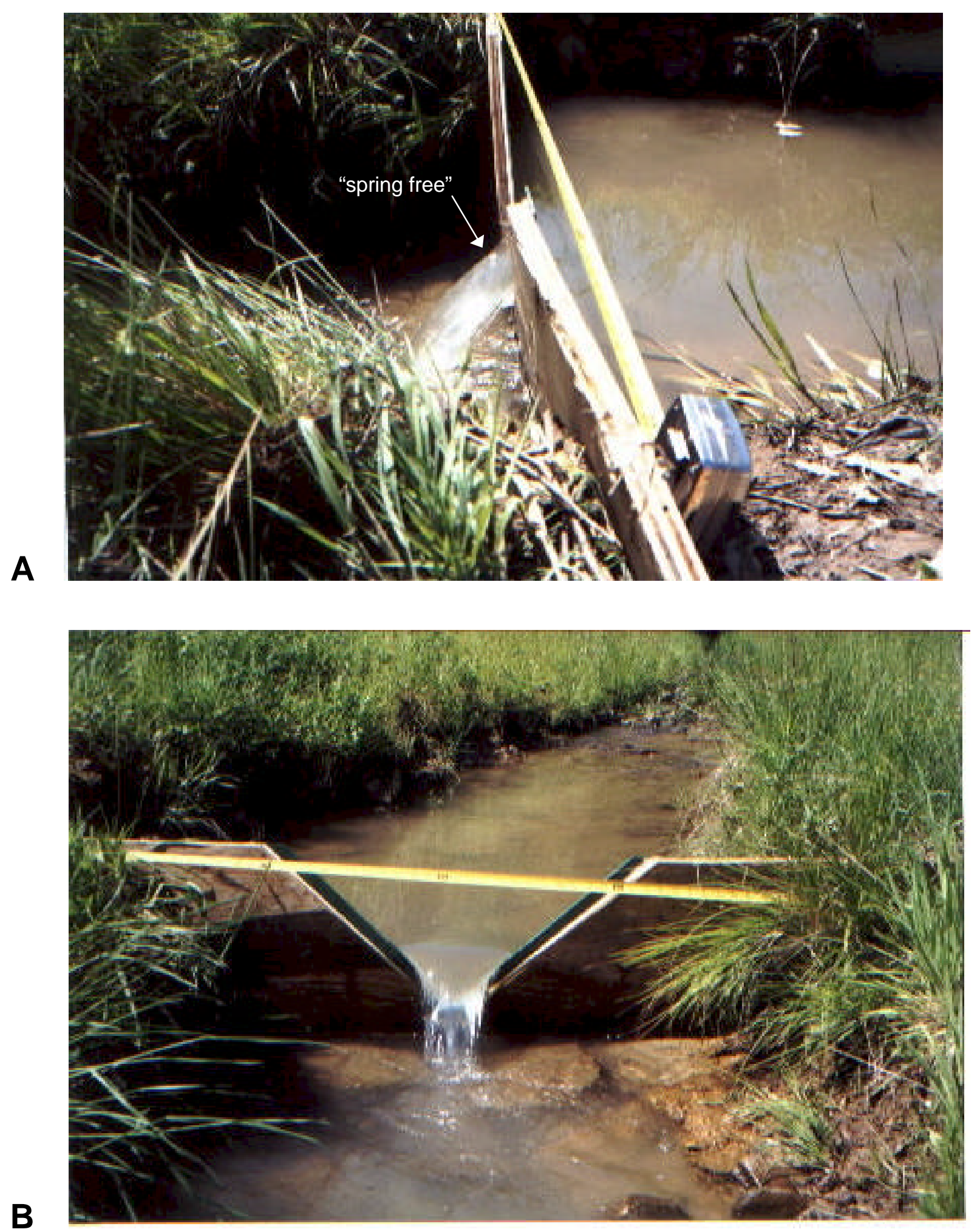

Figure 11. Photo A shows a profile view of an installed weir along Stream $J$ with the water "springing free" as it passes through the V-notch. Photo B shows this weir, looking upstream. Water ponds on the upstream side of the weir and flows through the V-notch. 


\section{Flow Meter Method}

Stream velocity for most streams in this study was measured with a Marsh-McBirney flow meter (Model \#201). The stream channel cross-section was divided into at least 10 equally spaced vertical segments by first measuring the width of the selected reach with a tape measure and then dividing the stream into individual segments based on its total width (Figure 12). Water depth $\left(d_{i}\right)$ and velocity ( $V i)$ were measured at the midpoint of each segment. Average flow velocity was measured for each of the segments at a point 0.6 times the stream water depth. The product of width $\left(w_{i}\right)$, depth $\left(d_{i}\right)$, and velocity $\left(v_{i}\right)$ for each segment yielded discharge $\left(q_{i}\right)$ for that segment by the equation:

$$
q_{i}=v_{i} d_{i} w_{l}
$$

The process was repeated for each segment of the cross-section. Total discharge, $Q$, is the summation of individual segmented discharge values for a stream with n segments (Fetter, 1994):

$$
Q=\sum q_{i}
$$

\section{Water Temperature}

Water temperature was measured with a mercury thermometer to help detect locations where ground water fed stream flow. It is hypothesized that reemergence of water into the stream from a shallow unconfined aquifer would be characterized by a decrease in temperature from mixing of cooler ground water with warmer surface water during the warmer months of the year. 


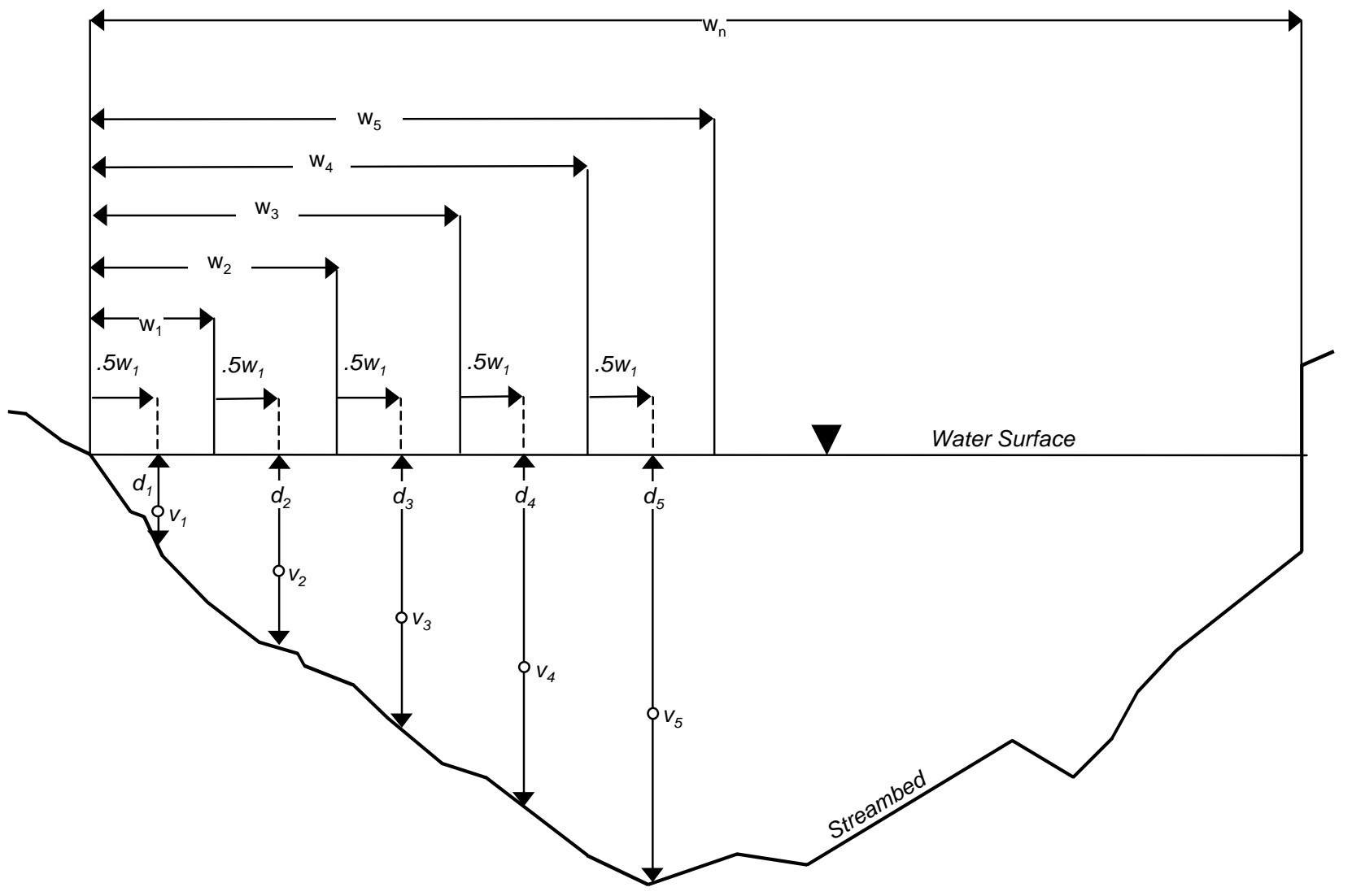

$\mathrm{w}_{\mathrm{n}}=$ a stream divided into $\mathrm{n}$ width segments

$\mathrm{w}_{1}=$ individual segment width $\left(\mathrm{w}_{2}=2 \times \mathrm{w}_{1}, \mathrm{w}_{3}=3 \times \mathrm{w}_{1}\right.$, etc. $)$

$\mathrm{d}_{1}=$ midpoint depth for segment 1

$.5 \mathrm{w}_{1}=$ half the individual segment width

$v_{1}=$ measured velocity of segment 1 at 0.6 times the stream water depth from the water surface

Figure 12. Stream cross-section that has been divided into segments for the measurement of stream discharge with a flow meter (modified from Dingman, 1994). 
Stream water temperature is influenced by a number of factors. The most important of these factors are the temperature of streamflow entering the channel $\left(T_{\text {in }}\right)$, the heat advected into the stream reach by ground water discharge $\left(T_{g w}\right)$, the outside air temperature in the form of incoming short-wave and long-wave solar radiation $\left(T_{r}\right)$, and the heat content of flow leaving the stream ( $\left.T_{\text {out }}\right)$ (Figure 13)(Stevens, et al., 1975). The heat energy budget can be expressed in a simple relation (Stevens, et al., 1975):

$$
T_{r}+T_{\text {in }}+T_{\text {gw }}-T_{\text {out }}=T_{x}
$$

where:

$$
T_{x}=\text { change of heat content of water in the reach (+ for increase). }
$$

Measurements of water temperature were taken at each flow monitoring station. Stream water was placed in a $160-\mathrm{ml}$ plastic container and then the thermometer was placed in the container. The container was then placed back into the stream for at least three minutes to ensure a proper temperature measurements for each reach. Temperature was also used to normalize the specific conductivity measurements to $25^{\circ} \mathrm{C}$.

\section{Specific Conductivity}

Specific conductivity is a measure of the ability of water to conduct an electrical current. It is expressed in microsiemens per centimeter at 25 degrees Celsius $(\mu \mathrm{S} / \mathrm{cm})$. Specific conductance is related to the type and concentration of ions in solution and was measured to help detect locations of ground water 


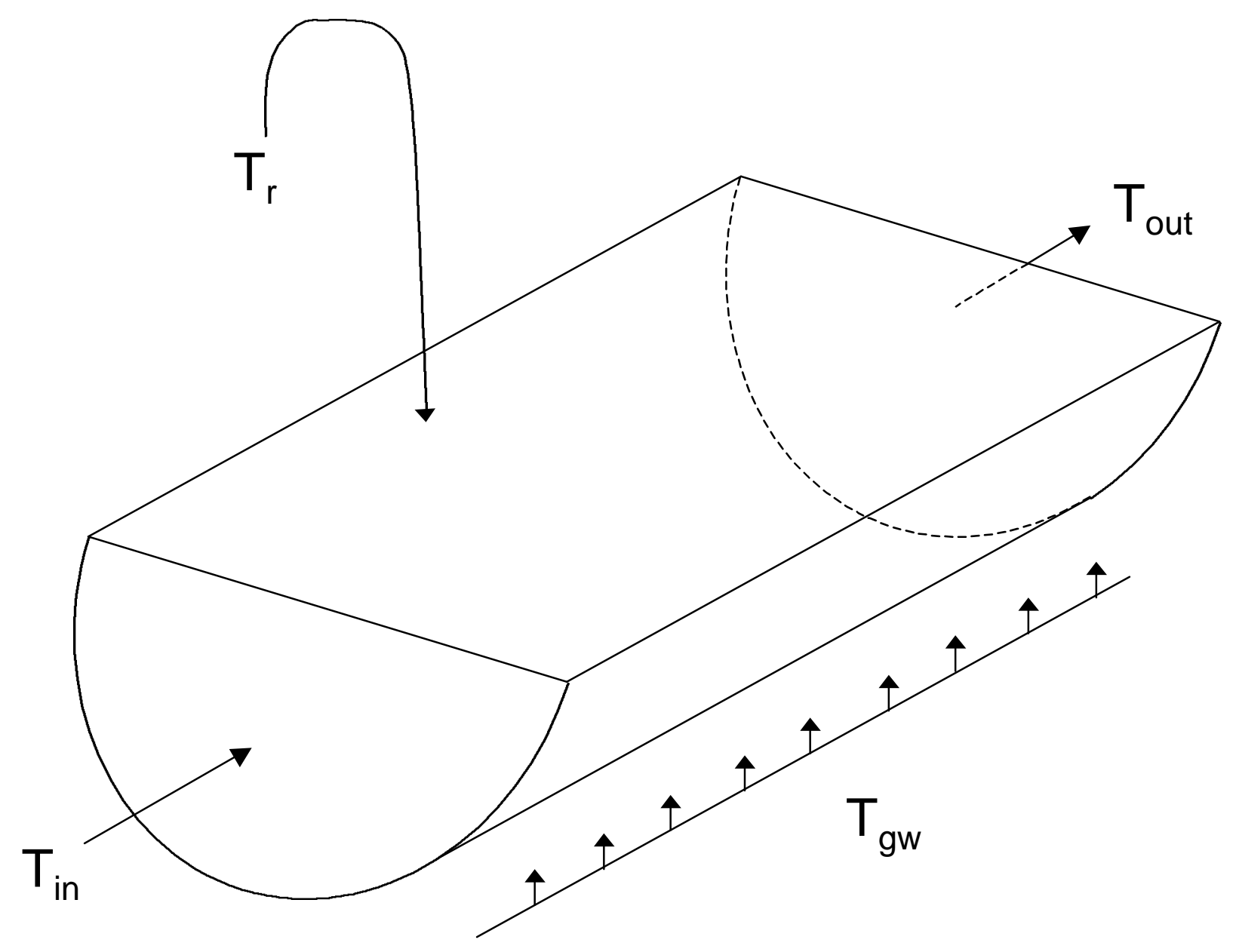

Figure 13. Four of the principal energy components in the heat balance of small streams (modified from Pluhowski, 1970). 
discharge to the streams and to distinguish between re-emergence of channel underflow and other spring flows (Evaldi and McClain, 1989). As with temperature, it is hypothesized that stream water conductivity containing reemerging underflow would be higher if it had mixed with ground water, or if the water had traveled through small cracks in the upper bedrock zone.

\section{Alluvium Thickness and Wolman Pebble Count}

Alluvium thickness was measured at every station for each measured stream. Alluvium thickness is important because, under the right conditions, alluvium could serve to protect the stream channel from dewatering by filling in rock fractures or joints (Reed, 1998). The effectiveness of alluvium in armoring the channel is also a function of sediment size and fracture aperture (Reed, 1998). A 42-inch long metal rod was thrust into the streambed until refusal at three scattered locations near each stream station. The three measurements were taken at approximately 10 feet from each other to differentiate bedrock from large boulders buried beneath the streambed. The depth of the bar below the stream channel bottom was interpreted as the depth of alluvium. The three measurements were averaged to estimate mean alluvial thickness for each station.

Wolman pebble counts were conducted at five selected streams in order to seek trends between alluvium particle size and dewatering. These five streams were selected based on the presence of dewatering. Two streams that

did not show any signs of dewatering were used as controls. A 30-foot tape was 
placed length-wise down the thalwag of the stream and measurements of the intermediate axis length were taken at every one-foot increment. A total of 30 measurements were made at each stream station for the five streams. The tape measure was positioned so that the 15 -foot measurement was at the staked monitoring location, which allowed an equal amount of measurements to be taken both upstream and downstream of each station.

\section{Data Analysis}

\section{Streamflow}

In order to properly measure any mine-dewatering effects on a stream, it is imperative that stream discharge measurements be made only during times when baseflow conditions exist. Baseflow, as defined by Fetter (1994), is the part of stream discharge deriving from ground water seeping into the stream. To ensure that stream discharge measurements would be made only during baseflow, a basic formula can be applied from Fetter (1994):

$$
D=A^{0.2}
$$

where: $\quad D=$ number of days between storm peak and the end of overland flow

$$
A=\text { drainage basin area in square miles }
$$

As a precaution, measurements were not taken until a full day after the recommended time $\mathrm{D}$.

\section{Baseflow Recession Constant}

All discharge measurements throughout the monitored streams could not be taken at exactly the same time, which meant that comparison among stream 
monitoring stations for discharge would be biased by time differences for these measurements. Discharge for any one location on a stream is in constant flux, either increasing or decreasing with time. Streams containing surface water runoff or snowmelt will have less predictable discharge over time when compared to streams containing baseflow only. Baseflow recession, as defined by Fetter (1994), is the declining rate of discharge over time of a stream fed only by baseflow for an extended period. Figure 14 shows a stream hydrograph that is separated into overland-flow and baseflow components with the aid of equation 6. The baseflow recession equation (Fetter, 1994) is:

$$
Q_{t}=Q_{o} e^{-a t}
$$

where: $\quad Q_{t}=$ discharge at some time $t$ after the recession curve started $\left(\mathrm{L}^{3} / \mathrm{T}\right)$

$Q_{0}=$ discharge at the start of the recession curve $\left(L^{3} / T\right)$

$a=$ recession constant for the basin $(1 / T)$

$\mathrm{t}=$ time since recession began when $\mathrm{Q}_{\mathrm{o}}$ was measured (T)

The recession constant can be determined (Fetter, 1994):

$$
a=-(1 / t) \ln \left(Q_{t} / Q_{0}\right)
$$

After all stream stations were measured once during a day of field work, the first measured upstream station was measured again to calculate the baseflow recession constant for that stream, using equation 8 . The baseflow recession constant was applied to each measured stream station to effectively adjust discharge measurements to be what they would have been if they had been measured at the same time, using equation 7 . 


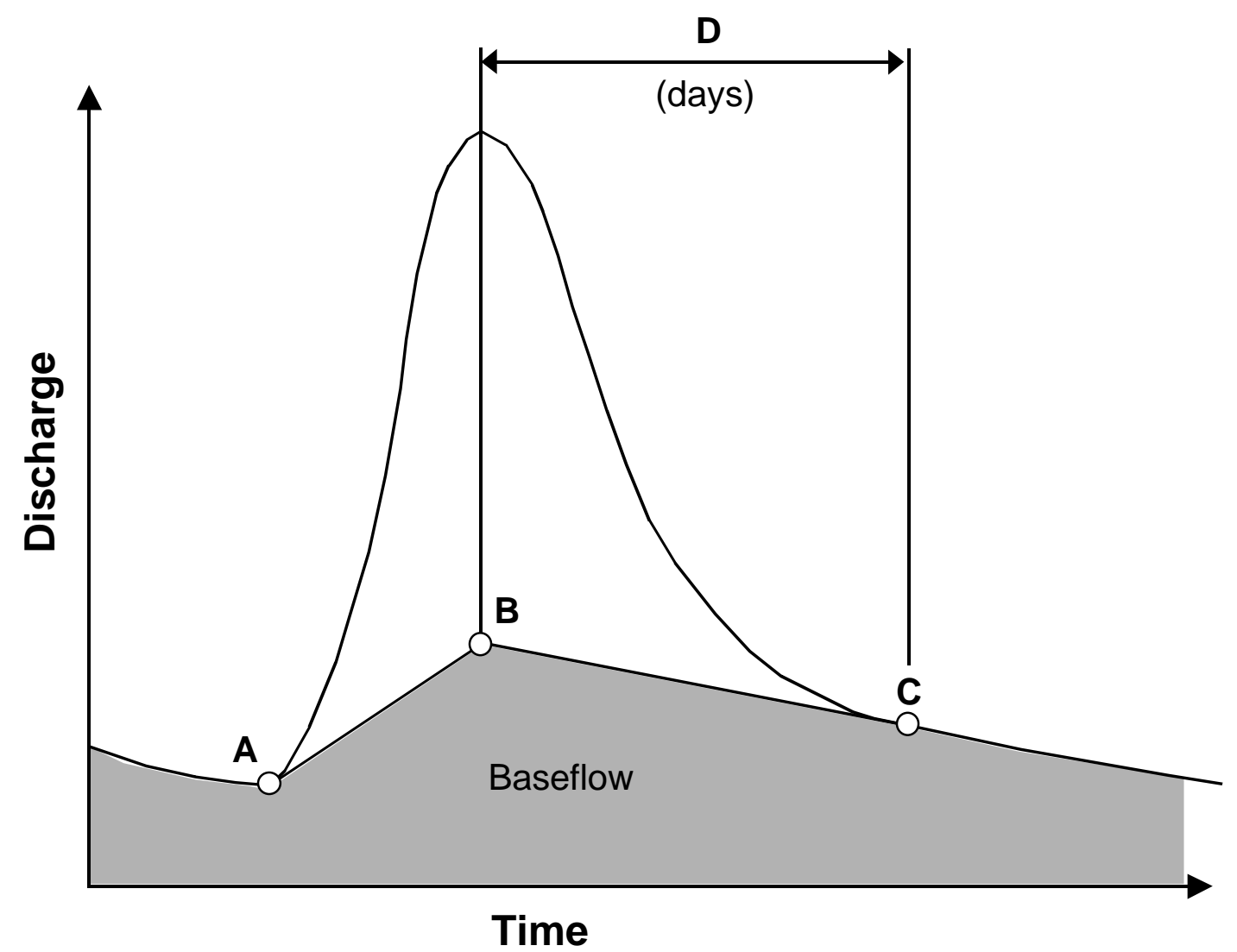

$A=$ beginning of surface runoff after rainfall

$\mathrm{B}=$ ordinate of the maximum baseflow discharge

$\mathrm{C}=$ end of all surface runoff

$\mathrm{D}=$ number of days between storm peak and the end of overland flow

Figure 14. Components of a surface stream hydrograph (Modified from Kresic, 1997). 


\section{Adjusted Discharge: Area Ratio}

After adjusting discharge for non-concurrent flow measurement, there was still a need to adjust for the influence of drainage area on discharge, so stream discharge data could be compared directly to determine any mining impacts separately from natural flow variations. Discharge was adjusted for drainage area by dividing discharge by the total drainage area above each monitoring station. Monitoring stations and their corresponding basin-drainage divides were carefully traced on a topographic map. A clear plastic overlay with a grid spacing of known dimensions was used over the map to determine the drainage basin area in acres. Tributary discharge and drainage area were subtracted out of cumulative basin totals, wherever necessary, to better understand overall impacts of mining on main-stream channel sections (Figure 15).

Figure 16 shows a hypothetical drainage basin that was divided into subbasins ( $A 1, A 2, A 3$, and $A 4)$, based on the location of stream discharge monitoring stations (Q1, Q2, Q3, and Q4). The adjusted stream- discharge: area ratio (gpm/acre) for Q1 was calculated by dividing the time adjusted discharge (gpm) at Q1 by the area (acres) of sub-basin A1. Sub-basin A2 includes the cumulative area of upstream basin A1, and the corresponding time adjusted discharge value at Q2 is determined by flow from the entire stream, up to that point. The same follows for the remaining downstream stations. 


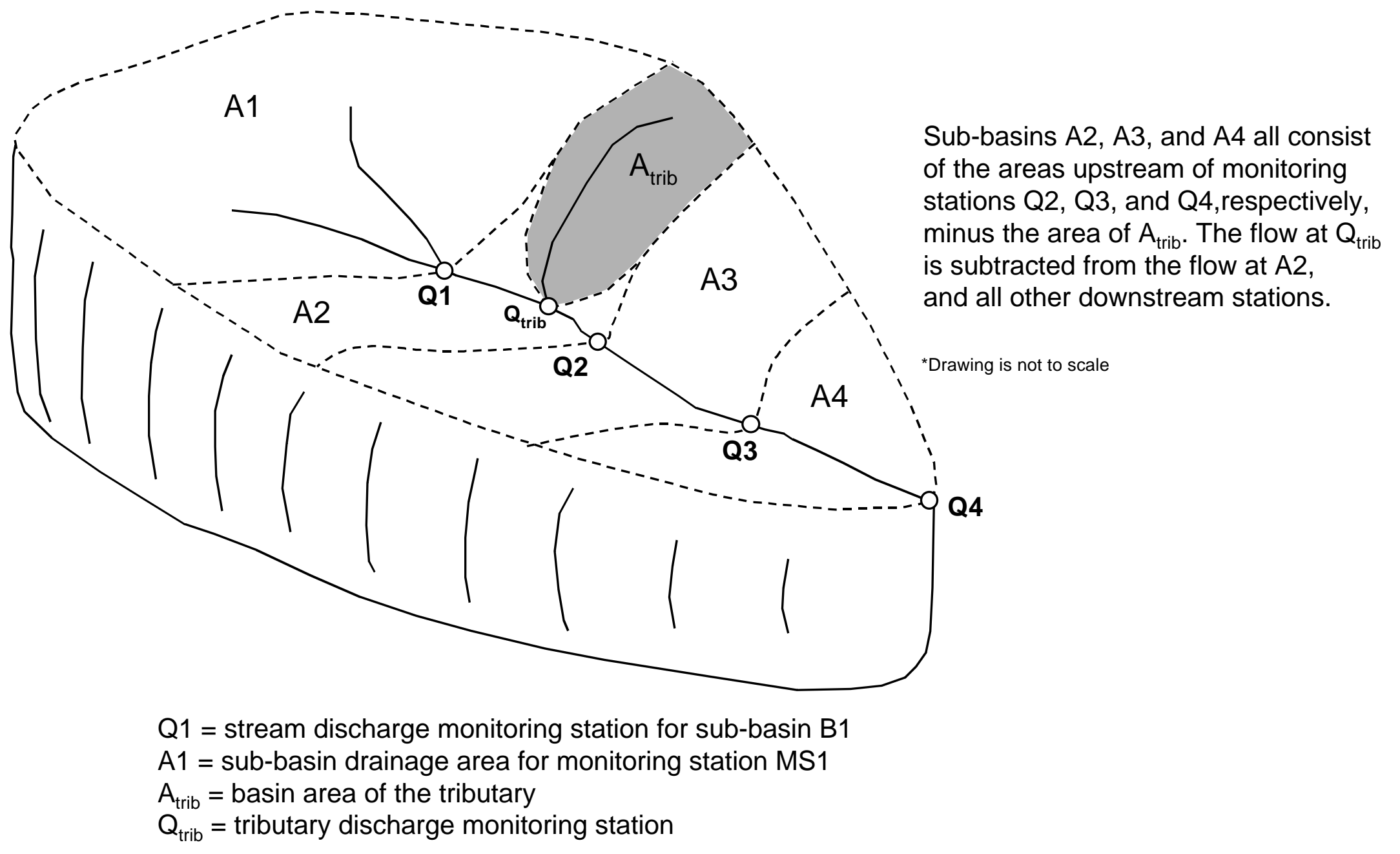

Figure 15. Schematic of a drainage basin divided into sub-basins, with tributary basin area and tributary discharge subtracted from overall measurements. 


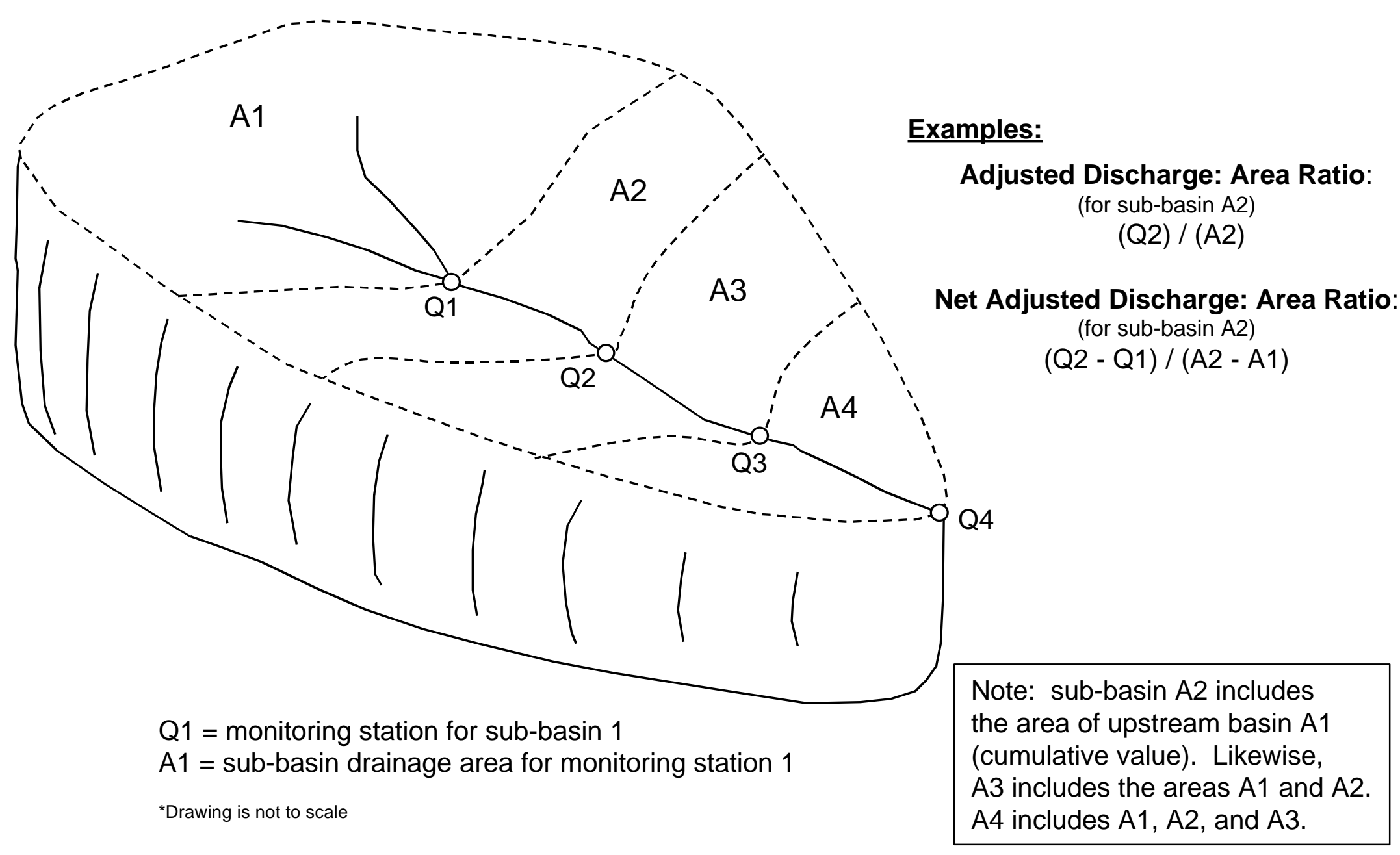

Figure 16. Schematic of a drainage basin divided into sub-basins, defined by the location of monitoring stations. 


\section{Net Adjusted Discharge: Area Ratio}

In an effort to better determine net stream discharge losses or gains between adjacent individual stations, net adjusted discharge: area ratio plots were constructed. The net adjusted discharge: area ratio is the difference in discharge (in gpm) divided by the difference in watershed drainage area (in acres) between consecutive monitoring stations. Net streamflow losses are considered to occur where a negative discharge ratio difference in gpm/acre units occurs. Net streamflow losses were considered to represent streamflow lost into subsurface underflow and, conversely, net streamflow gains were considered to represent underflow water re-introduced into the stream channel.

To calculate the net adjusted discharge: area ratio of $\mathrm{Q} 2$, the following equation can be used (Figure 16):

$$
(\mathrm{Q} 2-\mathrm{Q} 1) /(\mathrm{A} 2-\mathrm{A} 1)=\text { Net } \mathrm{Q}: \mathrm{A}_{\text {ratio }}
$$

After careful examination of the net adjusted discharge: area ratio plots, it was realized that these plots with their associated error bars do not yield additional useful information beyond that for the adjusted discharge: area ratio plots. Therefore, these plots are not used in this study but the calculations of net adjusted discharge: area ratio can be found for each stream in Appendix A.

\section{Graphical Analysis}

Adjusted discharge: area ratios (gpm / acre) were plotted against downstream distance (feet) in an effort to recognize any significant gains and losses in discharge. A cumulative discharge: area ratio was first plotted. The cumulative or total discharge ratio is the cumulative downstream discharge 
divided by the cumulative watershed acreage. This calculation was made in an attempt to identify any differences in trends between adjusted discharge: area ratio and total flow. Specific conductivity and temperature were plotted, along with the adjusted discharge: area ratios versus distance downstream. Both conductivity and temperature values were plotted using a secondary y-axis.

Whenever possible, data collected by Carver (1994) for the Mine Z study area were plotted along with the adjusted discharge: area ratio data for this study. The locations of longwall panels were shown on the stream discharge plots.

\section{Measures of Error}

\section{Discharge}

As with any study, there is a certain amount of error associated with field data measurement. According to Driscoll (1986), weirs can provide stream discharge measurements to an accuracy of plus or minus 10 percent or less. For stream segments where discharge was measured by the use of weirs (Stream J, stations J2-J10), vertical error bars were placed on the plotted data points allowing for this error. Marsh McBirney (1984) states the accuracy of flow meter Model \#201 for measured stream velocity is plus or minus 2 percent of the reading or 0.05 feet/second, whichever is greater. The U.S. Geological Survey assumes stream discharge measurements determined by flow meter and crosssectional flow areas to be accurate to plus or minus $\leq 10$ percent, (Dingman, 1994, p.476). For the purpose of this study, a conservative assumed error of 
plus or minus 15 percent was associated with measured discharge based on flow meter and flow cross-sectional area readings, due to probable $>10$ percent error associated with low flow conditions.

\section{Acreage of Drainage Basins}

Considerations for determining error for the drainage basin size were made based on the error associated with the actual placement of the contour lines on the 7.5 minute topographic maps and variations between drainage divides of individual drainage basins, which were sketched onto the topographic maps. Drainage sub-basin divides were sketched onto a map several different ways to allow for possible variations in drainage basin area. In areas where subbasins are small, less than 20 acres, the error will be much higher than compared to that of large sub-basins of greater than 100 acres. Therefore, the amount of estimated area error associated with $<20$-acre sub-basins was assumed at 20 percent, plus or minus. The area error for sub-basins larger than 20 acres was assumed as being negligible. All basin areas exceeded 20 acres, with only some sub-basin area values less than 20 acres (Appendix C). 


\section{RESULTS}

\section{Streamflow}

\section{Introduction}

A total of nine streams were monitored for discharge, specific conductivity, temperature, and alluvial thickness. Seven lie in the vicinity of Mine $Z$ and two are in the vicinity of Mine C. Several streams studied by Tieman (1986) and Carver (1994) were reanalyzed at Mine Z, and two streams studied by Dixon (1988) were reanalyzed at Mine C. Table 1 lists the dates when data were collected for the nine streams.

Table 1. Measurement events for streams at both Mine Z and Mine C.

\begin{tabular}{|l|l|l|l|}
\hline \multicolumn{1}{|c|}{ Date } & \multicolumn{1}{|c|}{ Stream } & \multicolumn{1}{c|}{ Measurement } & Baseflow Condition \\
\hline $4-25-99$ & $\mathrm{~J}$ & D, C, T & High \\
\hline $4-29-99$ & $\mathrm{~J}$ & D, C, T & Medium \\
\hline $5-3-99$ & G, H, K & D, C, T, A & Medium / High \\
\hline $5-21-99$ & J & D, C, T, A & Low \\
\hline $6-11-99$ & S1 & D, C, T, A & Low \\
\hline $6-16-99$ & J, S2 & D, C, T & Low \\
\hline $7-12-99$ & SF & D, C, T, A & Low \\
\hline $7-21-99$ & SF & D, C, T & Low \\
\hline $7-26-99$ & SF & D, C, T & Low \\
\hline $8-9-99$ & $\mathrm{X}, \mathrm{Y}$ & D, C, T, A & Low \\
\hline $8-11-99$ & K, J, S1 & WPC & not important \\
\hline $8-18-99$ & $\mathrm{X}, \mathrm{Y}$ & WPC & not important \\
\hline
\end{tabular}

\section{KEY:}

$\mathrm{D}=$ discharge measurements, $\mathrm{C}=$ specific conductivity measurements, $\mathrm{T}=$ temperature measurements, $A=$ alluvium thickness measurements, $W P C=$ Wolman pebble count measurements.

" = measurements at Mine C; other measurements are for Mine Z. 


\section{Stream Analysis for Mine Z}

In this section, each stream is individually examined and trends are identified, as indicated from plots of adjusted stream discharge: area ratio, temperature, conductivity, and alluvial thickness in relation to the underlying mine. Combined plots of stream adjusted discharge: area ratio, temperature, and specific conductivity are included and evaluated for each stream.

\section{Stream X and Stream Y (August 9, 1999 monitoring)}

Streams $\mathrm{X}$ and $\mathrm{Y}$ are grouped together because they are control streams and share very similar results. These control streams are located over nonundermined areas and are necessary to demonstrate the accuracy of some assumptions made about undermined streams. Basin $\mathrm{Y}$ is located in the southwestern section of the Mine Z property and extends south (upstream) onto

another coal company's property (Figure 3). This other coal company is actively mining in the vicinity of Stream Y's basin (Mine Z employee, personal communication, 1999). The upstreamost station (Y7) was positioned far enough north of the other company's active mining to avoid possible mining subsidence impacts on stream stations farther down stream (north). The remaining stretch of Stream $\mathrm{Y}$ north of $\mathrm{Y} 7$ is not undermined.

Discharge data (Figure 17) for Stream Y show a consistent Q:A $A_{\text {ratio }}$ (discharge to drainage area ratio) for all stations, with all $Q: A_{\text {ratio }}$ values plotting well within the allowed error bars; thus no mining impacts are evident. 

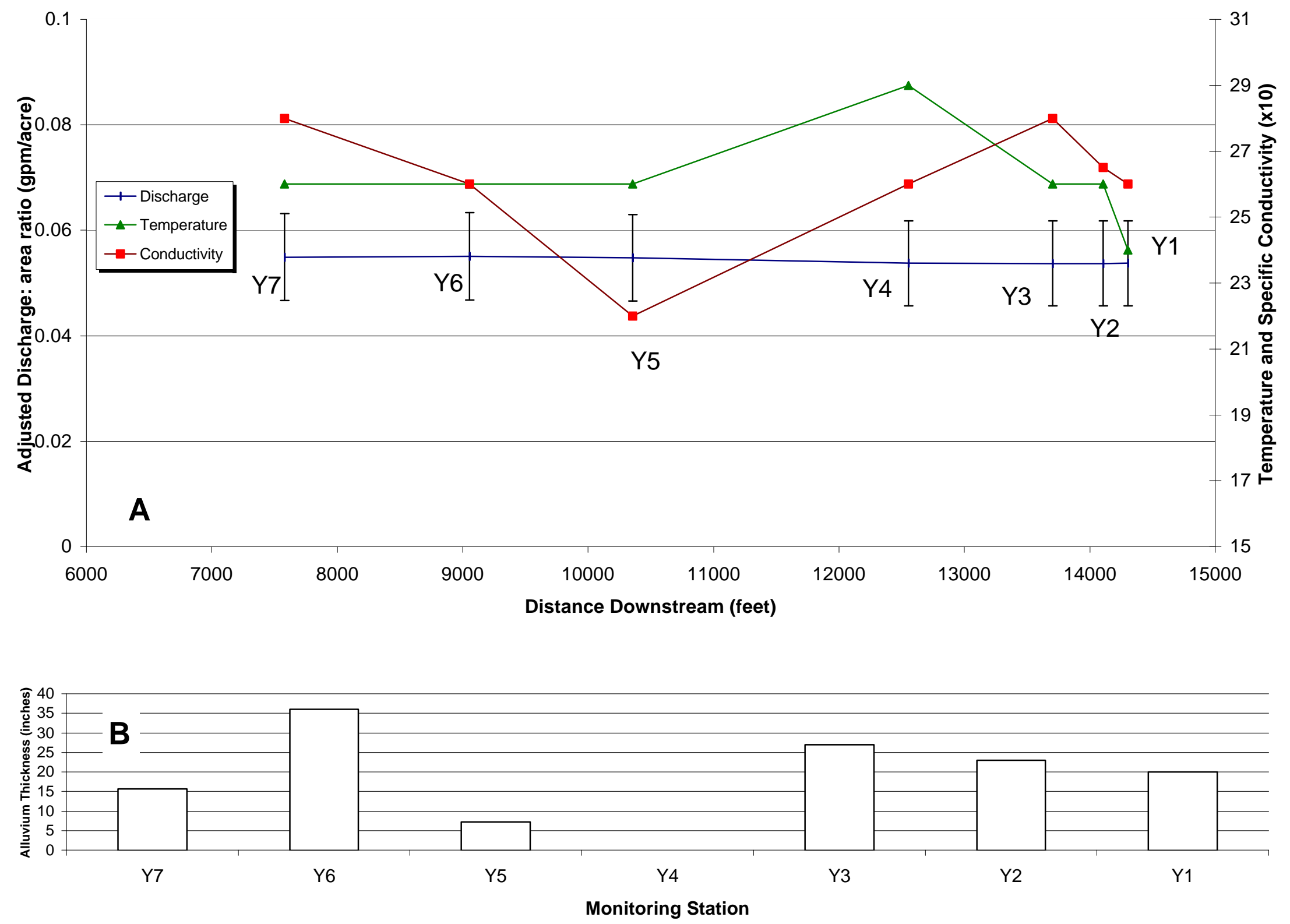

Figure 17. Plots of downstream distance along Stream $Y$ at Mine $Z$ versus $(A)$ adjusted discharge: area ra specific conductivity, and temperature; (B) alluvium thickness. Data were obtained on August $\mathrm{C}$ 1999. Vertical bars represent assumed error for discharge to area ratio data. 
Control Stream X is located partially in the extreme southwest corner of Mine Z property (Figure 3). As with Stream Y, Stream X originates off of the Mine Z property, and flows over partially undermined areas. Again, precautions were taken to ensure that any possible subsidence effects from the adjacent coal company's mining would not affect sub-basin areas for stations further down stream (north). The Q:A $A_{\text {ratio }}$ for Stream X (Figure 18) shows a consistent trend, similar to that for Stream $Y$ on Figure 17, and again reflects no mining impacts.

The amount of alluvium in the streambed does not have an effect on streamflow for non-undermined watersheds (Figures 17 and 18). Stations Y4 and X2 have bedrock exposed in the streambed, which does cause specific conductivity to increase, but does not affect the $\mathrm{Q}: \mathrm{A}_{\text {ratio. }}$. These data, for both Figures 17 and 18, suggest that streams outside undermined areas will have a consistent $Q_{\text {ratio. }}$

\section{Stream H}

Both Tieman (1986) and Carver (1994) studied Stream H. During Tieman's study (1986) 23 percent of basin H1 had experienced longwall and pillar extraction subsidence. Tieman found no evidence for a net loss of water from the entire $\mathrm{H}$ watershed. At the time of Carver's study of the same stream, 59 percent in the $\mathrm{H} 1$ basin had experienced longwall and pillar extraction subsidence. Although a large increase in undermined area had occurred, it seemed to have had little negative effect on the stream. The $Q: A_{\text {ratio }}$ actually 

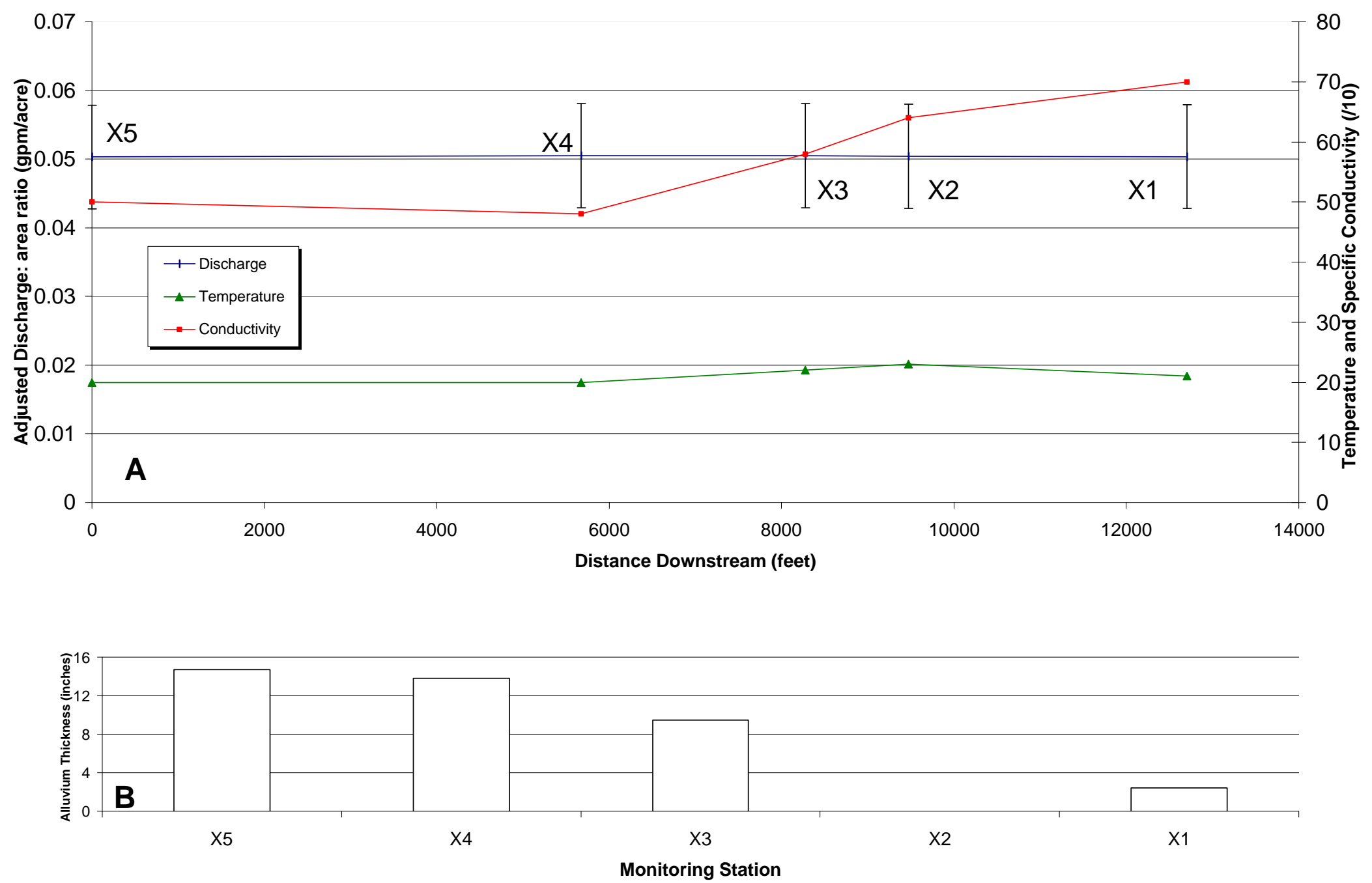

Figure 18. Plots of downstream distance along Stream $X$ at Mine $Z$ versus (A) adjusted discharge: area ratio, specific conductivity, and temperature; (B) alluvium thickness. Data were obtained on August 9 , 1999. Vertical bars represent assumed error for discharge to area ratio data. 
increased as the stream flowed downstream. Carver suggested that, compared to non-undermined streamflow, longwall mine subsidence more than 6.4 years old may increase stream discharge under low baseflow conditions.

Stream H was measured on May 3, 1999, at relatively high baseflow levels. The adjusted discharge: area ratio plot (Figure 19) shows no significant variation between adjacent monitoring stations, with all stations showing error bars overlapping each other. This suggests little, if any, dewatering impacts from mine subsidence for Stream $\mathrm{H}$. The mined panels range from 11.5 to 7.5 years old. The $\mathrm{Q}: \mathrm{A}_{\text {ratio }}$ increase from station $\mathrm{H} 2$ to station $\mathrm{H} 1$ could be measurement error, or perhaps, some underflow resurfacing to the stream between these stations.

This resurfacing underflow theory is supported by specific conductivity increasing at each consecutive downstream station. A possible explanation for the increase in $\mathrm{Q}: \mathrm{A}_{\text {ratio }}$ and conductivity is that in basin $\mathrm{H}$, the upper portion of Stream $\mathrm{H}$ is mostly located in the Rush Run sandstone horizon of the Greene Formation (Carver, 1994, p. 137-139). This sandstone aquifer probably allows more underflow to occur at upstream stations $\mathrm{H} 3$ and $\mathrm{H} 2$ than at downstream stations $\mathrm{H} 1$ and $\mathrm{H} 4$, which are underlain by mudstone confining units. Some underflow is probably forced upwards to the Stream $\mathrm{H}$ channel between stations $\mathrm{H} 2$ and $\mathrm{H} 1$. The downstream stream water temperature decrease also suggests water is mixing with fresh ground water seepage. 

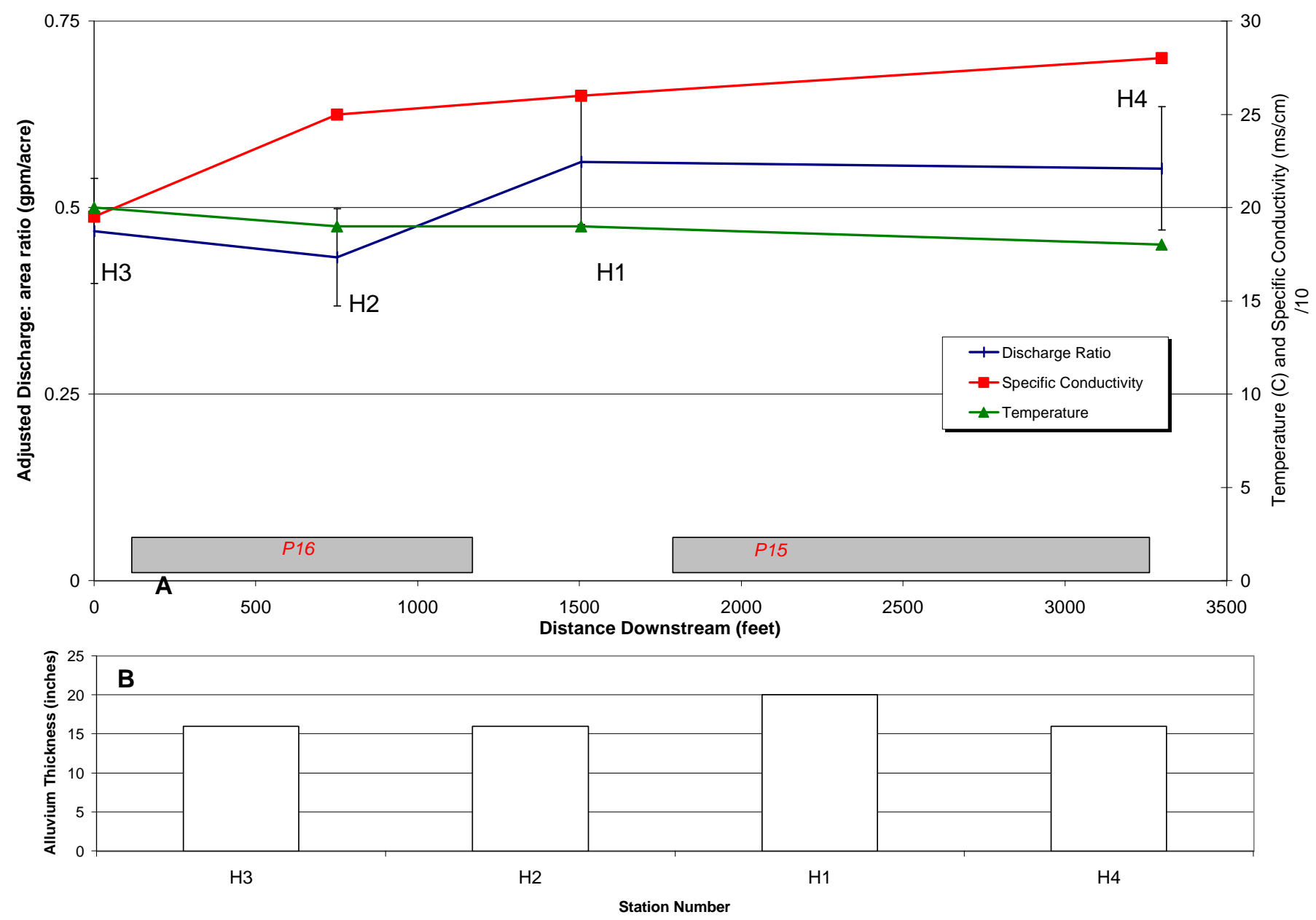

Figure 19. Plots of downstream distance along Stream $H$ at Mine $Z$ versus (A) adjusted discharge: area ratio, specific conductivity, and temperature; (B) alluvial thickness. Data were obtained on May 3, 1999. Vertical bars represent assumed error for discharge to area ratio data. Indicated longwall panels have been mined. 


\section{Stream G}

When Tieman (1986) studied basin G, sub-basin G5, which was 28 percent undermined, was the only sub-basin that showed signs of dewatering. This was the largest percentage of undermining in comparison to the rest of basin G. Tieman suggested that stream loss could be related to the younger panels. Carver (1994) re-analyzed Stream G under high baseflow conditions. The dewatering seen by Tieman was not apparent in Carver's data, suggesting no substantial dewatering. No new mining has occurred under Stream G since the time of Tieman's and Carver's work.

Stream G was monitored again on May 3, 1999. The $Q: A_{\text {ratio }}$ increases for each downstream station, suggesting no stream losses from mining (Figure 20). All values for $Q: A_{\text {ratio }}$ show overlapping error bars, suggesting that they are relatively consistent.

All of the monitoring stations, except G5, are located in an area underlain by fireclay (Carver, 1994, pp.137-139). The Rush Run sandstone aquifer intercepts Stream G between station G5 and G3. Ground water runoff from this aquifer could account for increases in streamflow between G5 and G3, as well as increases in temperature and conductivity there, as shown in Figure 20.

\section{Stream K}

Figure 21 shows Stream K monitoring stations, longwall panel locations, drainage basin divides, and areas where bedrock is exposed in the stream bed. Subsidence fractures are evident in the bedrock. At the time of Carver's (1994) 


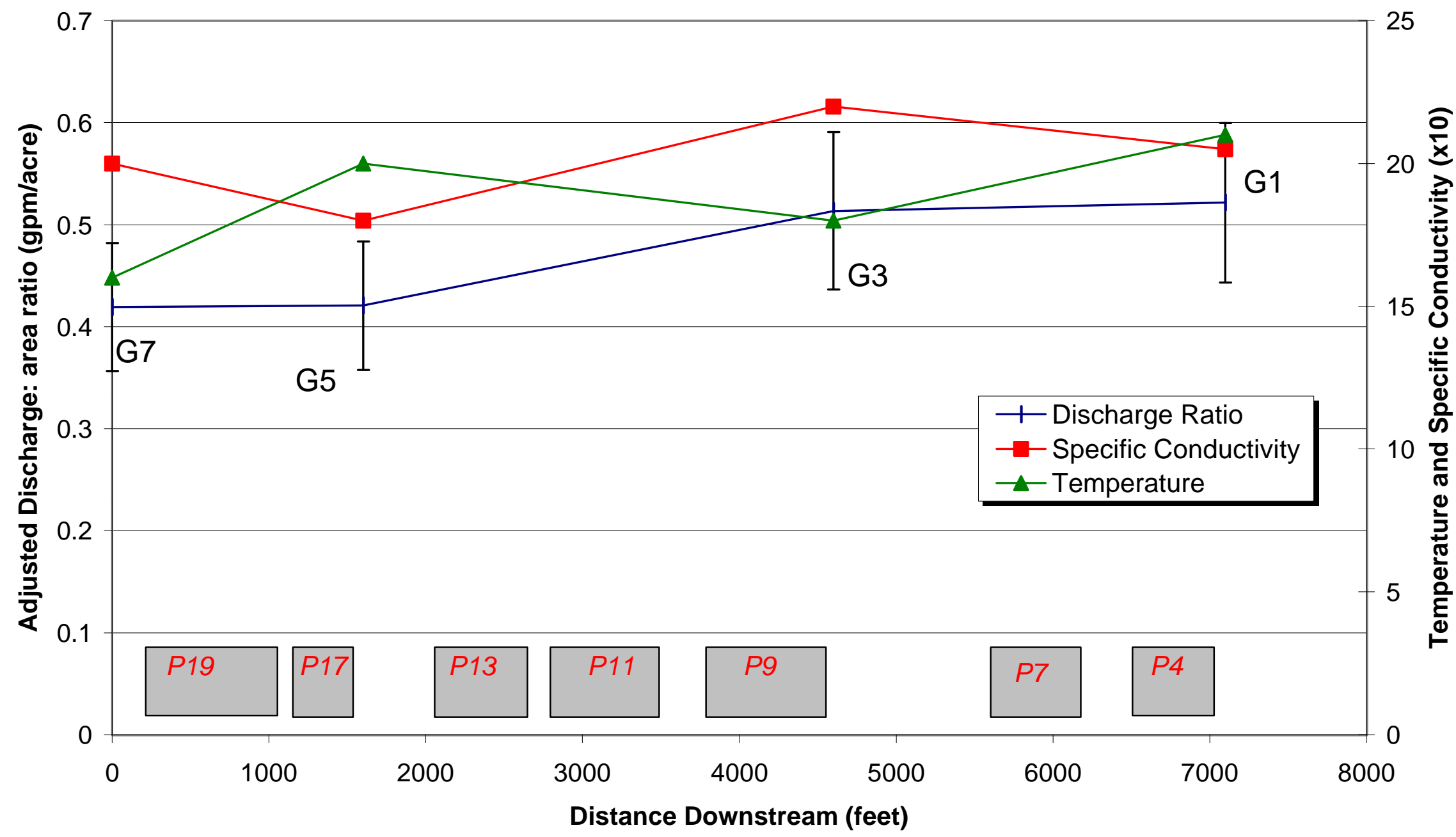

Figure 20. Plots of downstream distance along Stream $G$ at Mine $Z$ versus adjusted discharge: area ratio, temperature, and specific conductivity. Data were obtained on May 3, 1999. Vertical bars represent assumed assumed error for discharge to area ratio data. Indicated longwall panels have been mined. 


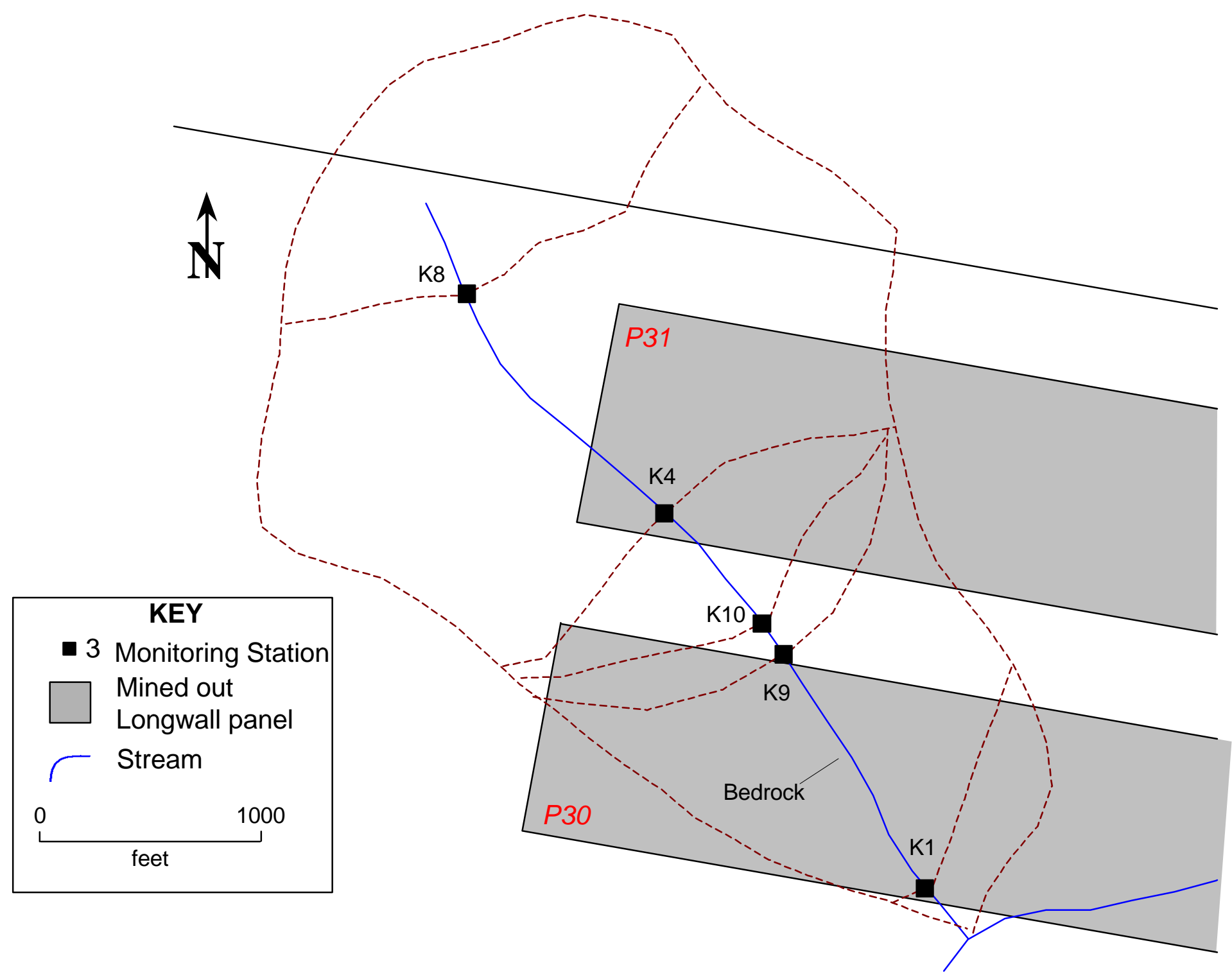

Figure 21. Close up view of monitoring stations and basin boundaries for Stream K at Mine Z. 
investigation of Stream K, only panel P30, mined 7.5 years ago, was interfering with streamflow. Panel P31 was mined after Carver's field work. The section of panel P31 underlying Stream $\mathrm{K}$ was mined 6.5 years ago.

Carver's data (Figure 22) show Stream K decreasing in discharge from K8 to K9. Downstream of K9, the streambed became dry for a stretch and flow reappeared at station K1. Carver suggested that Stream K showed angles of dewatering influence between $4^{\circ}$ and $16^{\circ}$ for the beginning of the dry segment and station 10, respectively, defining a zone of stream dewatering caused by panel P30. A comparison of discharge data obtained on May 3, 1999, with those of Carver shows very similar trends. Discharge decreases downstream from station $\mathrm{K} 8$ to $\mathrm{K} 9$ and then completely disappears into the subsurface. The decrease in discharge is less severe from $\mathrm{K} 10$ to $\mathrm{K} 9$, suggesting that some of the subsidence fractures in this area have closed there, which would reduce the amount of water leaking into the sub-surface. The data suggest that K10 may be affected by both panels P31 and P30, creating an overlapping zone of dewatering for that area. The angles of dewatering influence for stations $\mathrm{K} 10$ (Panel P30), and K9 (Panel P30) are $15^{\circ}$ and $4^{\circ}$, respectively. Flow totally disappears approximately 200 feet downstream of $\mathrm{K} 9$ and reappears approximately 400 feet before K1. The stream bottom consists entirely of Rush Run sandstone throughout this reach. 

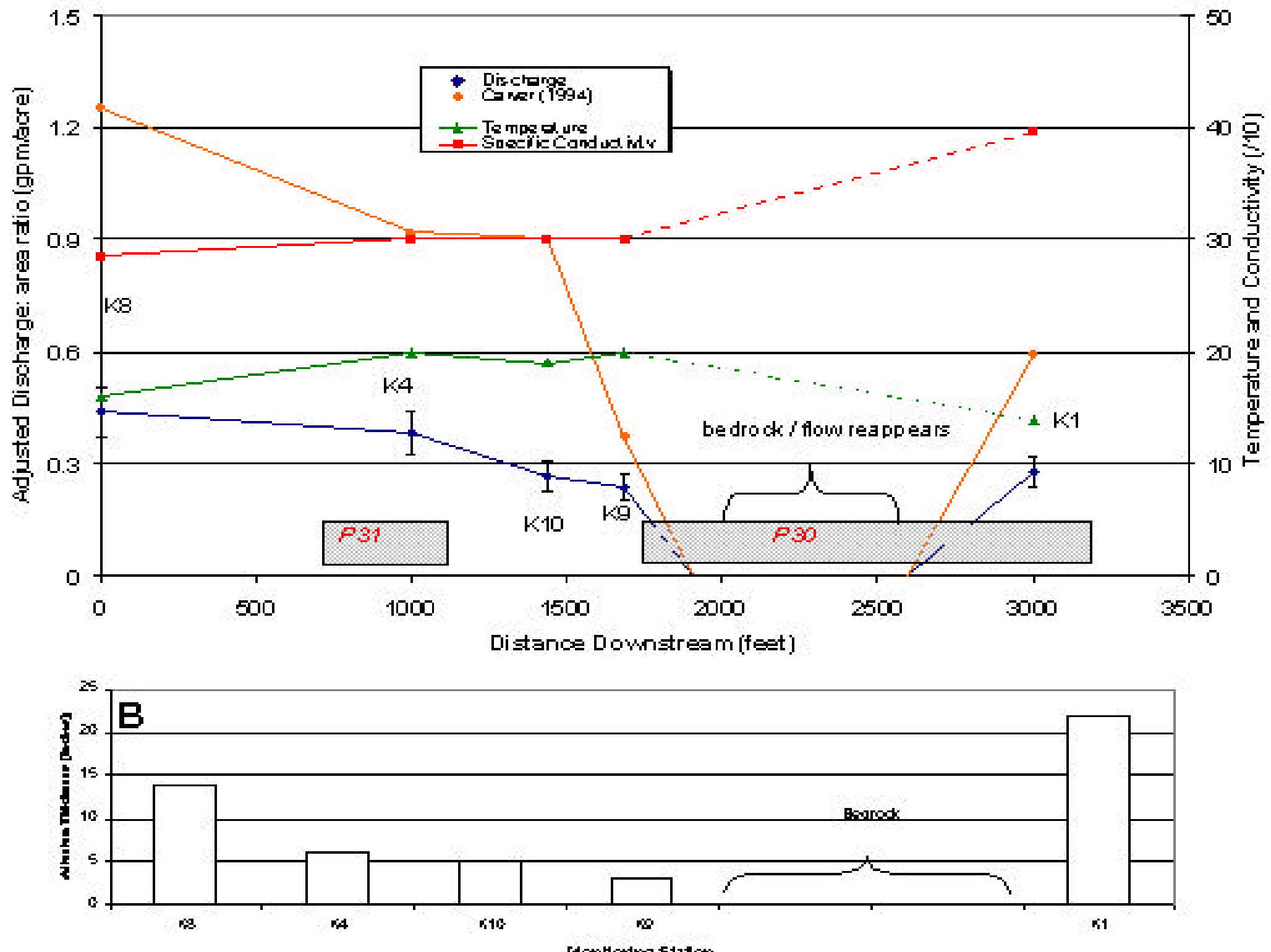

Figure 22. Plots of downstream distance along Stream $K$ at Mine $Z$ versus (A) adjusted discharge: area ratio (this study), Carver (1994) adjusted discharge: area ratio, temperature, specific conductivity; (B) alluvium thickness. D ata were obtained on May 3, 1999. Vertical bars represent assumed error for discharge to area ratio data Longwall panels above have been mined out. 
Flow, for the most part, is totally absent in this reach, which exhibits subsidence fractures in the bedrock channel bottom. The amount of flow that returns at $\mathrm{K} 1$ is approximately 64 percent of the flow at K8, the normal or unsubsided discharge for this basin.

An increase in specific conductivity from $300 \mu \mathrm{S} / \mathrm{cm}$ at $\mathrm{K} 9$ to $395 \mu \mathrm{S} / \mathrm{cm}$ at $\mathrm{K} 1$ (Figure 22) and a decrease in temperature at the same stations suggest that underflow is returning to the channel there. Re-emerging streamflow at $\mathrm{K} 1$ was influenced by upstream ground water underflow that flowed through subsidence fractures in the sandstone to increase the amount of total dissolved solids in the water and decrease the water temperature.

Results from Stream K data suggests that lack of alluvial cover also contributes to loss of streamflow (Figure 22). Comparison of alluvial thickness with the area adjusted $Q: A_{\text {ratio }}$ plot shows that as the alluvial cover thins, dewatering is more prevalent. Where no alluvial cover is present, streamflow is non-existent. Partial flow returns at K1, probably because of thick alluvium and a lessening stream gradient at that point.

\section{Stream SF}

Stream SF (Figure 23) has the largest drainage basin of any streams studied at Mine Z and flows northeastward towards the Monongahela River. As 


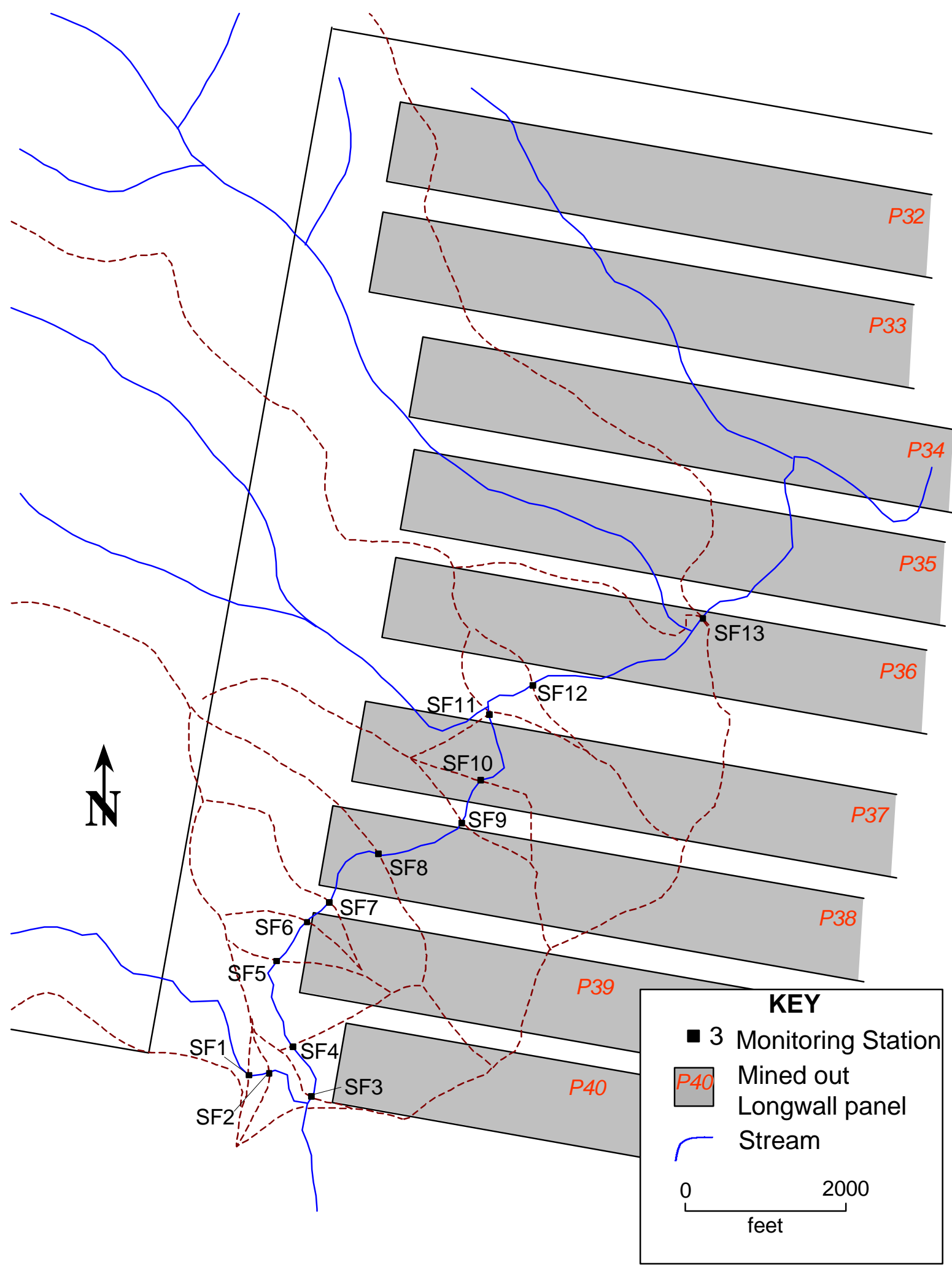

Figure 23. Location of all monitoring points along Stream SF at Mine Z. Stream SF tributaries are indicated but not fully drawn. 
Stream SF flows downstream, it crosses over many different longwall panels that increase in age to the northeast, making this an excellent stream for examining the effects of mined longwall panel age on degree of stream dewatering. Stream SF was monitored on three separate occasions.

\section{July 12, 1999 monitoring}

Discharge, specific conductivity, temperature, and alluvial thickness measurements were made for all stations along stream SF on July 12, 1999, when baseflow conditions were low. Stream SF can be divided up into four reaches based on flow conditions (1) pooled flowing water, (2) non-pooled flowing water, (3) pooled stagnant water, and (4) dry. All four types of flow conditions are plotted on the adjusted discharge ratio plot (Figure 24).

The adjusted discharge: area ratio plot for Stream SF (Figure 24) shows no apparent significant difference in discharge ratio between station SF1 and SF2, suggesting that these stations indicate the "normal" flow ratio for Stream SF. SF1 and SF2 are located over non-undermined areas and exhibit pooled flowing conditions. Tributary Stream X enters Stream SF just upstream of SF1, and tributary Stream Y empties into Stream SF between SF2 and SF3 as shown on Figure 3. Although the $Q: A_{\text {ratio }}$ at SF3 is within the error of $S F 1$, the $Q: A_{\text {ratio }}$ does increase slightly from SF2 to SF3. 


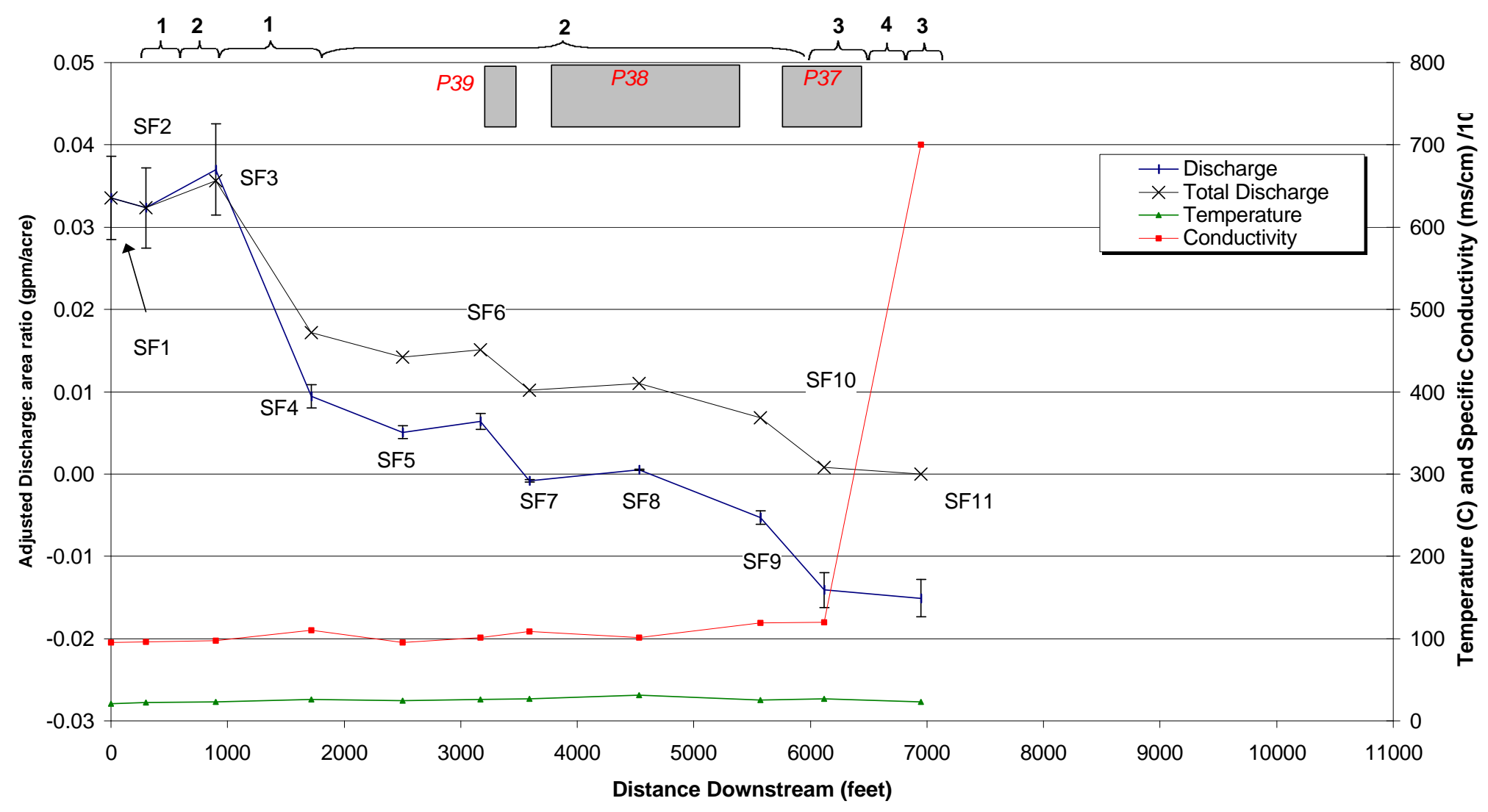

Figure 24. Plots of downstream distance for Stream SF at Mine Z, versus adjusted discharge: area ratio, temperature, and specific conductivity. Data were obtained on July 12, 1999. Vertical bars represent assumed error for discharge to area ratio data. The numbers along the top represent different flow conditions: 1 = pooled flowing water, $2=$ non-pooled flowing water, $3=$ pooled stagnant water, and $4=$ dry . Indicated longwall panels have been mined out. 
The Q: $A_{\text {ratio }}$ (Figure 24) and alluvial thickness (Figure 25) decrease dramatically from SF3 to SF4. These data suggest that water is lost to subsidence fractures adjacent to the west end of panel P40, which seems reasonable considering the close proximity of SF4 to panel P40 and the presence of bedrock in the stream channel at SF4. The angle of dewatering influence from panel P40 to SF4 is $29^{\circ}$. Where present, stream alluvium probably acts to seal subsidence fractures in shallow bedrock, such as at SF3, to preserve the streamflow. Personal communication with landowners in the vicinity of SF4, along with coal company officials, confirmed that there was no artificial pumping of water out of the stream along this reach.

$\mathrm{Q}: \mathrm{A}_{\text {ratio }}$ in general, decreases at consecutive downstream stations from SF4 to SF11 (Figure 24). Water is probably being lost at SF5 in a fashion similar to the loss at SF4. The location of SF5 is close enough to panel P39 to experience dewatering from adjacent subsidence fractures and with an associated angle of dewatering influence of $17^{\circ}$. No additional streamflow loss occurs between SF5 and SF6. SF6 is located on the western edge of panel P39. This panel's mined age ranges from August 1998 to February 1999, west to east. Streamflow stabilizes by SF6, possibly because of streamflow and underflow moving from a tensional bedrock zone at SF5 to a compressional zone at SF6, adjacent to panel P39. Such a compressional zone would encourage underflow water to exit bedrock fractures and resurface in the stream channel.

The adjusted discharge: area ratio of SF7 is a negative value on Figure 24. This does not mean that there was no flow at SF7, but, rather, the corrected 
discharge (actual flow minus tributary flow from streams $X$ and $Y$ ) value was less than zero. If there were no tributary flow coming into Stream SF, the stream channel would be dry at SF7. Overlapping angle of dewatering influence zones from adjacent panels P39 and P38 may cause the decrease at SF7.

Station SF9 is impacted by panel P38 mine subsidence and shows a slight decrease in $Q: A_{\text {ratio }}$ from SF8. Streamflow at station SF9 was very low when measured. Flow at SF10 was also quite low, with approximately 2.5 inches of mud in the stream channel, making it very difficult to take a proper discharge measurement. Stream dredging was implemented along Stream SF starting at SF8 and, continuing downstream, past the study area. Although there was ponded water in the stream channel, flow at SF11 was effectively zero, because of the effects of panel P37 mine subsidence. A very large, and, at first, confusing increase in specific conductivity occurs at SF11. This increase is caused by the introduction of treated mine water into the tributary, which enters Stream SF just north of SF11, and is not an effect of re-emerging underflow (Mine Z company, personal communication, 1999).

The alluvium thickness data for Stream SF (Figure 25) suggest that stream stations located within mine subsidence zones and having less than about 5 inches of alluvium show additional local water loss (SF4, 5, 9, 10, and 11). Stream stations in mine subsidence zones and having more than about 5 inches of alluvium showed little or no additional water loss (SF3, 6, and 8). The only exception to this trend is SF7, which shows significant local additional 


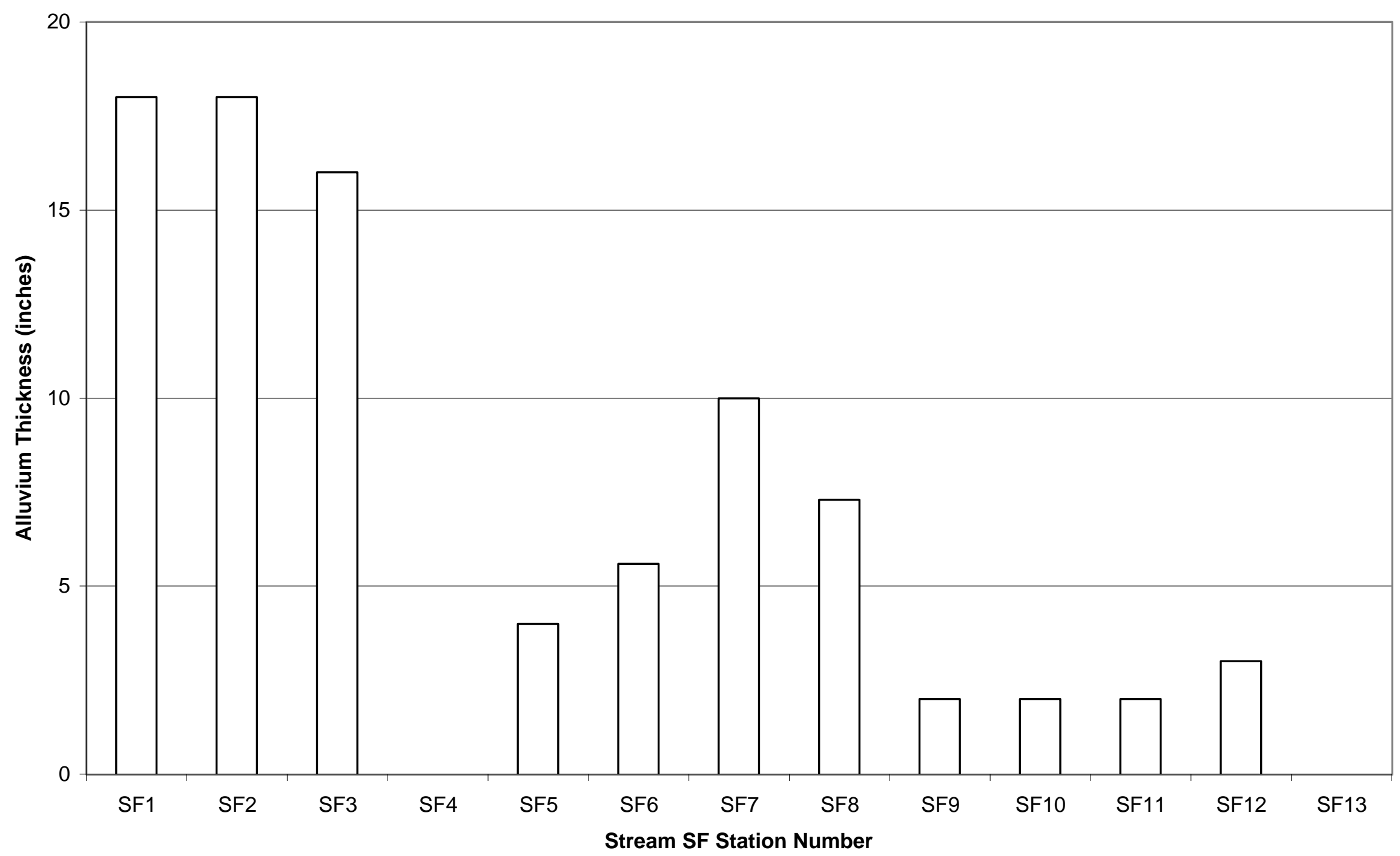

Figure 25. Plot of alluvium thickness for Stream SF at Mine Z. Data obtained July 12, 1999. 
dewatering despite having 10 inches of alluvium. A possible explanation for the SF7 water loss is the tensional subsidence setting of SF7 between panels P38 and P37, in contrast to the compressional subsidence setting of SF6 and SF8.

\section{July 21, 1999 monitoring}

A plot of data collected on July 21, 1999 shows very similar trends to that of previous data for Stream SF (Figure 26). Unfortunately, only stations SF1 through SF5 could be measured for discharge, specific conductance, and temperature because it began to rain during data collection at SF5. Baseflow conditions were very low because a major rainfall event had not happened for several months, and therefore the overall $Q: A_{\text {ratios }}$ for Stream SF on July 21 are less than those of the July 12 event. Negative $Q: A_{\text {ratio }}$ values, created from the subtraction of tributary discharge along Stream SF, occur further upstream of SF4 when compared to the July $12^{\text {th }}$ data.

\section{July 26, 1999 monitoring}

Stream SF stations SF1 through SF11 were measured again, along with two additional stations, SF12 and SF13, on July 26, 1999 (Figure 27). SF12 and SF13 were added as monitoring stations to better understand the influence of the large increase in conductivity witnessed during July 12 monitoring at SF11. The $\mathrm{Q}: \mathrm{A}_{\text {ratio }}$ trends are similar to previous data in Figure 24. The $\mathrm{Q}: \mathrm{A}_{\text {ratio }}$ for Stream SF steadily decreased downstream to SF8, where the stream channel became 


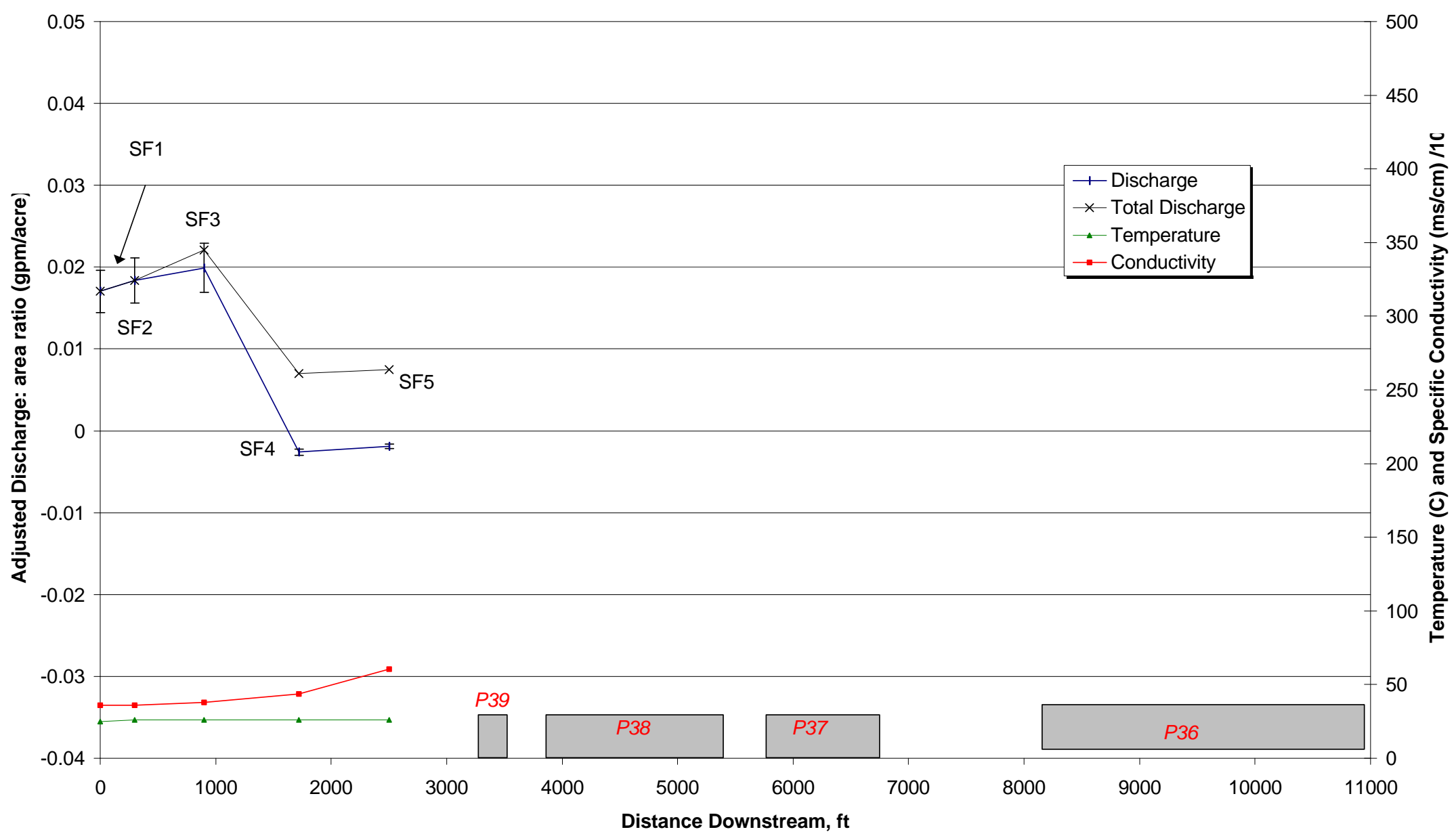

Figure 26. Plots of downstream distance for Stream SF at Mine Z, versus adjusted discharge: area ratio, temperature, and specific conductivity. Data were obtained on July 21, 1999. Vertical bars represent assumed error for discharge to area ratio data. Indicated longwall panels have been mined. 


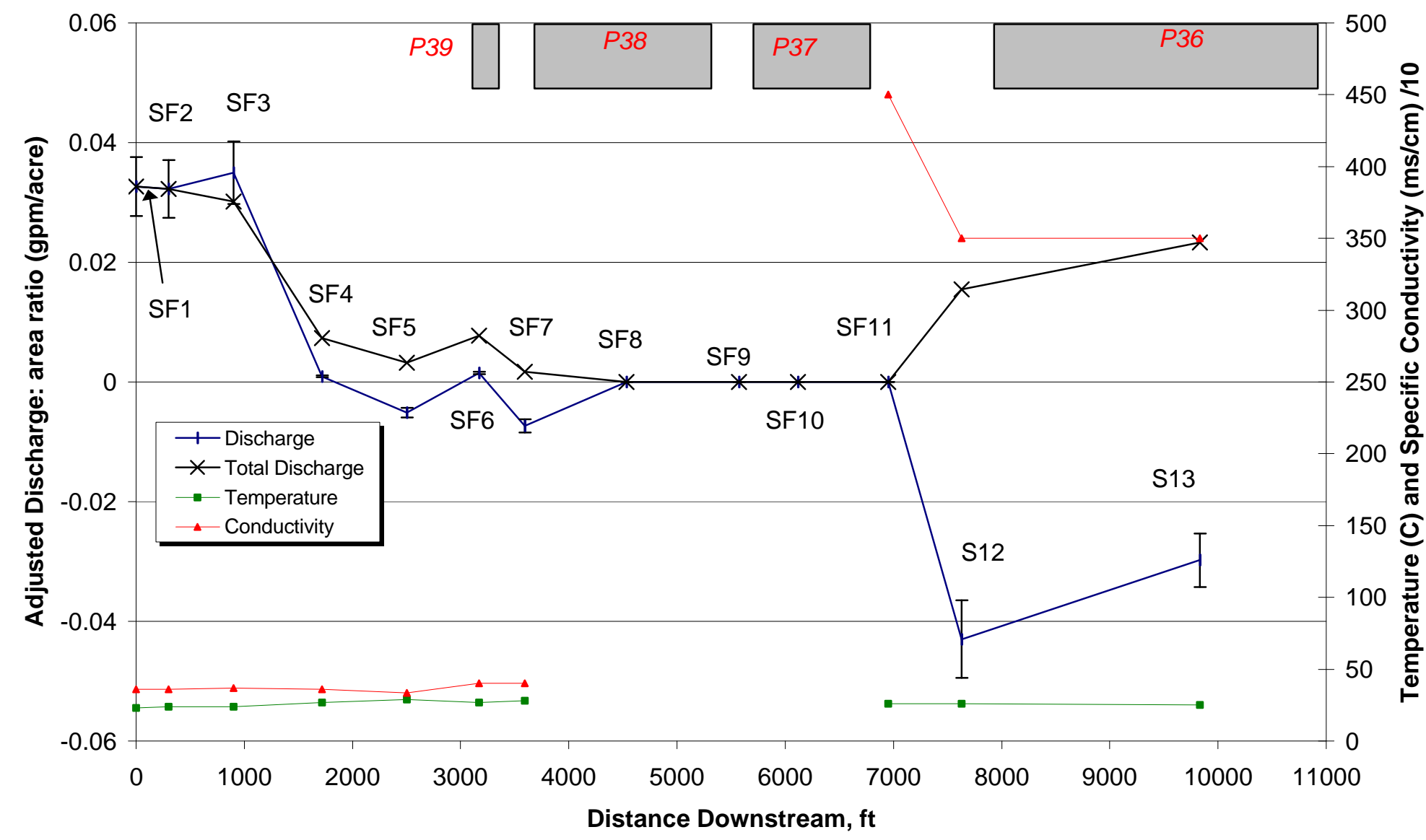

Figure 27. The plots of downstream distance for Stream SF at Mine Z, versus adjusted discharge: area ratio, temperature, and specific conductivity. Data were obtained on July 26, 1999. Vertical bars represent assumed error for discharge to area ratio data. Indicated longwall panels have been mined. 
dry. The dry stretch of stream may be caused by a compounding effect of undermining and drought conditions. This dry stretch continued to SF10. Flow re-appeared approximately 250 feet upstream of SF11. At SF11, water was pooled and flowing, but in the upstream direction.

Monitoring station SF11 is located approximately 20 feet upstream of a tributary that enters Stream SF. Water entering the main channel from the tributary was treated mine water released during the discharge measurements. This mine water had a very high conductivity $(4900 \mu \mathrm{S} / \mathrm{cm})$ and was flowing at $193 \mathrm{gpm}$. SF11 had a correspondingly high conductivity $(4500 \mu \mathrm{S} / \mathrm{cm})$, which suggests that the tributary water was flowing upstream and mixing with water at SF11. The author actually witnessed water flowing upstream at SF11. A topographic high, created by mine subsidence over an interpanel mine section, was located in stream channel SF at the confluence, and effectively split the tributary flow, with a majority of flow traveling upstream toward SF11. Measurements taken at SF11 (in the upstream direction) and at a temporary station 20 feet downstream of the tributary mouth show that 52 percent of the tributary discharge (101 gallons per minute) flowed upstream and only 44 percent of the tributary discharge (85 gallons per minute) flowed downstream. The four percent of tributary flow not accounted for relates to discharge measurement error or subsurface loss.

A rate of stream water loss due to the subsurface percolation rate, which is equal to the Darcy velocity, was calculated for the reach of Stream SF from the tributary junction to the point where the channel became dry (250 feet upstream 
of the tributary), near SF11. Darcy velocity, as defined by Fetter (1994), is a velocity representing the average percolation rate for water movement. This percolation rate is the average rate at which stream water leaves the wetted stream channel by vertical movement downwards. This concept is similar to the rate of water loss in a test hole during a soil percolation test, represented by the equation (Fetter, 1994):

$$
D_{v}=Q / A
$$

where:

$D_{v}$ is the vertical Darcy velocity;

$Q$ is the stream discharge being lost by vertical infiltration; $A$ is the wetted stream channel area over which water loss occurs.

Area was calculated by multiplying the average length of the stream segment in question by its average width (eight feet). The vertical Darcy velocity was calculated at $0.000113 \mathrm{ft} / \mathrm{s}$ or $0.407 \mathrm{ft} / \mathrm{h}$. This rate is the average at which water is flowing into and leaving the stream channel segment by vertical infiltration. The effective porosity of stream sediments, which allows this stream loss to occur, varies throughout the stream segment.

SF12 shows a $Q: A_{\text {ratio }}$ value of $-0.043 \mathrm{gal} / \mathrm{min} / \mathrm{ac}$. This $\mathrm{Q}: \mathrm{A}_{\text {ratio }}$ is so low because of two reasons. As water flows downstream from SF1, it can only travel as far as SF11 because of stream water loss into subsided ground, and the topographic high in the stream channel that restricts further downstream flow. Therefore, the only flow at SF12 is that fraction of discharge entering the system from the tributary near SF11. Also, the adjusted discharge: area ratio is determined from the channel flow and drainage area minus the tributary flow and 
drainage area. When the large amount of tributary flow entering Stream SF is subtracted from the small amount of actual SF streamflow at SF12, it yields a negative value.

The $Q: A_{\text {ratio }}$ increases between SF12 and SF13, suggesting there is little or no impact from panel P36. This conclusion is strengthened by the lack of alluvial cover at SF13. Hypothetically, if mining impacts occurred at SF13, the lack of alluvial cover, combined with the very low baseflow conditions, should eliminate flow. Since flow is evident at SF13, mining is not considered to be impacting the stream there.

Figure 28 illustrates all discharge events for Stream SF at Mine Z. Consistent trends occur in the data, with flow generally decreasing downstream of SF3. The decrease is thought to be a direct result of mining impacts of panels $\mathrm{P} 40,39,38,37$, and possibly 36 . These panels range in time since mining from 3 years (10/97) at P36 to 8 months (2/99) at P40. 


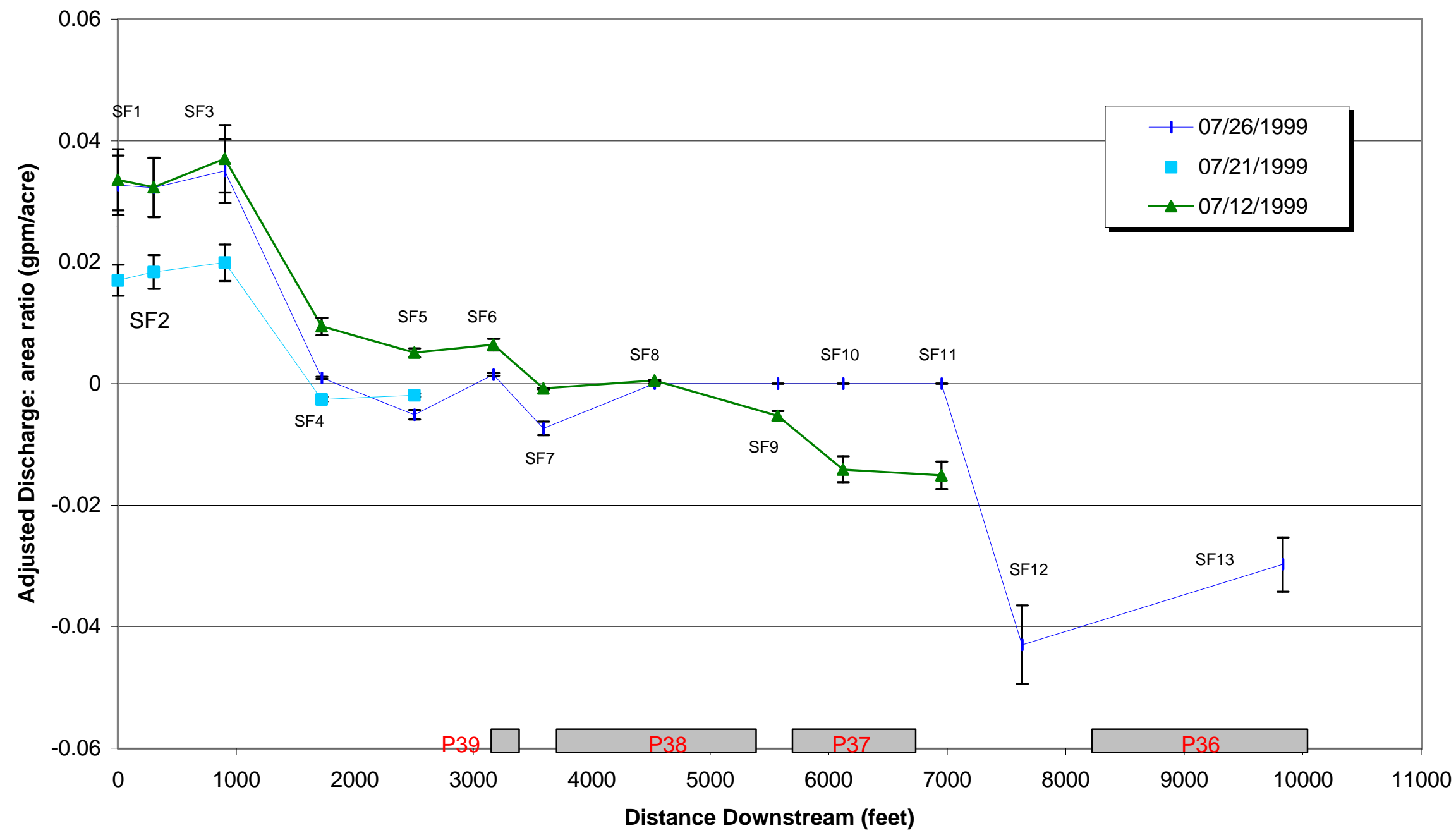

Figure 28. Plots of downstream distance along Stream SF at Mine Z, versus all adjusted discharge:area ratio data. Indicated longwall panels have been mined out. Vertical bars represent assumed error for discharge to area ratio data. 


\section{Stream J}

Stream $\mathrm{J}$ is located a little west of the center of Mine $Z$ (Figure 3). A close-up view of Stream $\mathrm{J}$ is given in Figure 29. Flow at monitoring point $\mathrm{J} 1$ was through a metal culvert pipe with corrugations 0.5 inches high, through which the southernmost first-order tributary of Stream $\mathrm{J}$ headwaters flowed. Flow at station J1 was measured using a modified Manning Equation (Fetter, 1994) for stream discharge through channels:

$$
Q=A(1.486 / n) R^{2 / 3} S^{1 / 2}
$$

where:

$$
\begin{aligned}
& \mathrm{Q}=\text { discharge }\left(\mathrm{ft}^{3} / \mathrm{sec}\right) \\
& \mathrm{R}=\text { hydraulic radius, or the ratio of the cross-sectional area of } \\
& \quad \text { flow to the wetted perimeter }(\mathrm{ft}) \\
& \mathrm{A}=\text { cross-sectional area of flow }\left(\mathrm{ft}^{2}\right) \\
& \mathrm{S}=\text { slope of the water surface (unitless) } \\
& \mathrm{n}=\text { Manning roughness coefficient }
\end{aligned}
$$

The height of the water was measured in the pipe and applied to equation 11. A value of 0.023 for the pipe was used for $n$ (Linsley, et al., 1975). Very small changes in the measurement of the depth of flow or the assumed $n$ value has a large impact on the value of $Q$. For this reason, a calculated error of 25 percent is used for station $\mathrm{J} 1$ discharge.

Weirs were installed along Stream J at stations J2-J10. Conditions were optimum for weir installation at these stations because of an incised channel and abundance of alluvium in the streambed. Downstream from station J10, bedrock occurred and the channel became too wide and shallow for proper weir installation. Stream discharge at stations $\mathrm{J} 11-\mathrm{J} 15$ was calculated using 


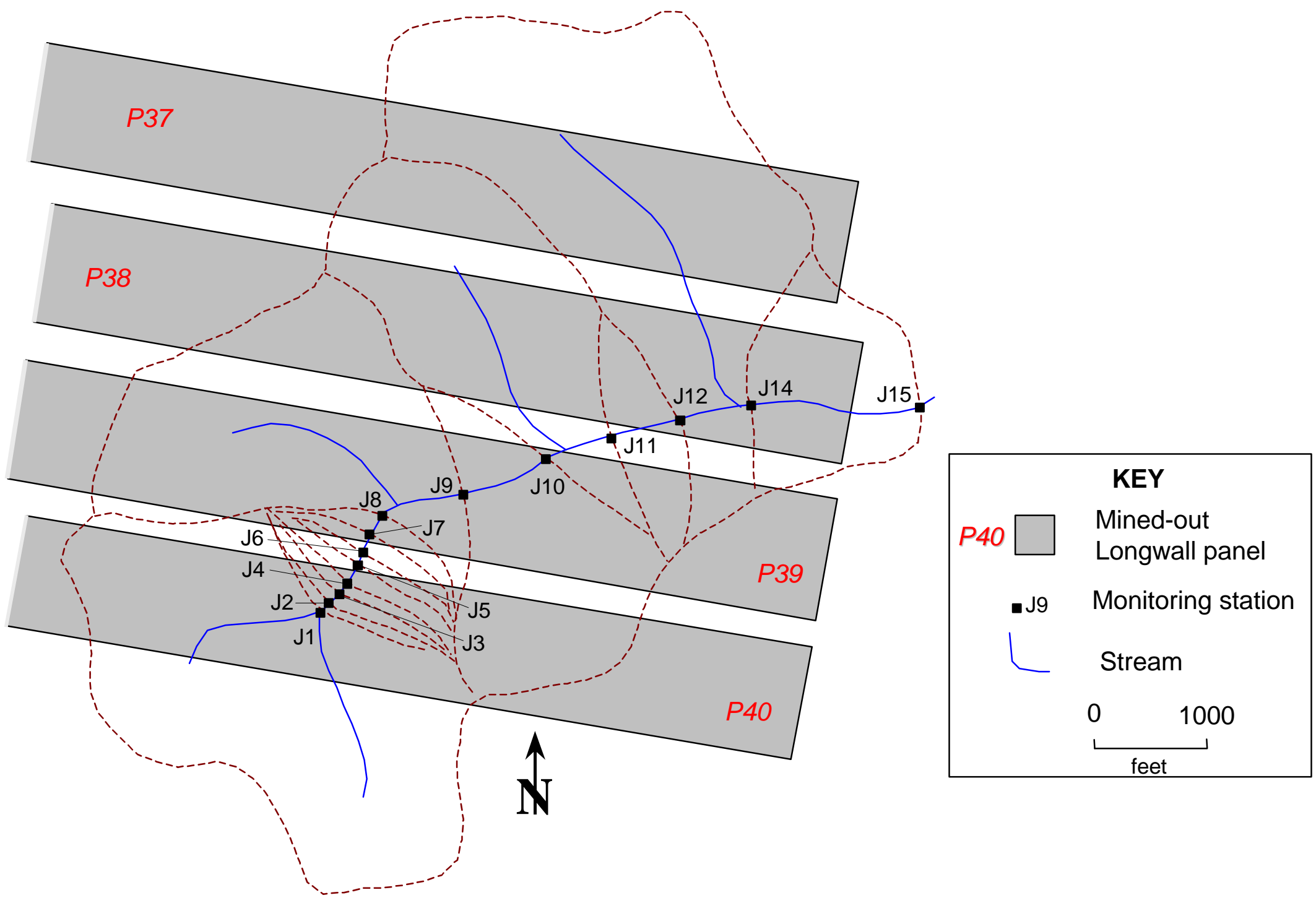

Figure 29. Location of monitoring stations and drainage basin boundaries for Stream $\mathrm{J}$ at Mine Z. 
measured sub-cross-sectional areas and average stream velocity, determined by use of a flow meter.

Discharge, temperature, and conductivity measurements were conducted on five separate occasions. Panel P40 was being mined during the time of this study, which allowed measurements to be conducted for both pre- and postmining conditions. Carver (1994) studied this stream as a control, before it was undermined.

\section{April 25, 1999 monitoring}

Streamflow was measured at stations $\mathrm{J} 1$, and $\mathrm{J} 4$ to $\mathrm{J} 10$ on April 25, 1999(Figure 30). Panel P40 had not been mined out at that time. Weirs at J2 and $\mathrm{J} 3$ were not installed properly, so flow could not be measured at that time. The adjusted discharge: area ratio plot shows a decrease in the Q:Aratio from J1 to J4. This decrease could be a result of mining impacts from panel P39. The maximum angle of dewatering influence is $32^{\circ}$ at $\mathrm{J} 1$ with a minimum angle of $24^{\circ}$ at J4. Dewatering continued at J5 with an angle of dewatering influence of $10^{\circ}$. The lost streamflow probably traveled as underflow. Flow increased slightly at J6. The increase between $\mathrm{J} 5$ and $\mathrm{J} 6$ was less than the measured error of $\mathrm{Q}: \mathrm{A}_{\text {ratio }}$ at these two points, and is therefore not significant. Stream $\mathrm{J}$ dewatering resumed from $\mathrm{J} 6$ to $\mathrm{J} 7$, with $\mathrm{J} 7$ showing significantly less $\mathrm{Q}: \mathrm{A}_{\text {ratio }}$ than $\mathrm{J} 6$, suggesting that the streamflow decrease resulted from subsidence fractures associated with panel P39. 


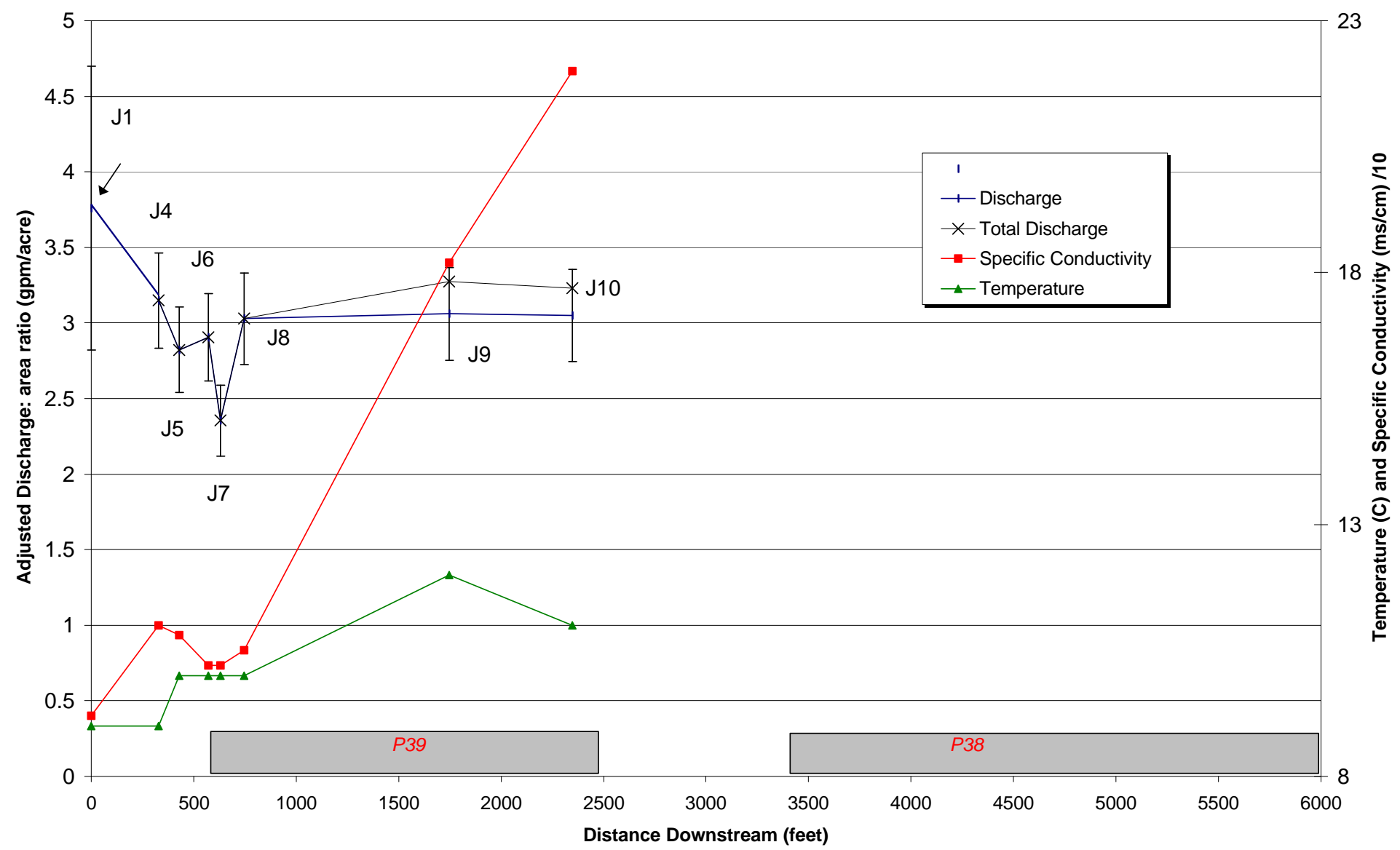

Figure 30. Plots of downstream distance for Stream $J$ at Mine $Z$, versus adjusted discharge: area ratio, temperature, and specific conductivity. Data were obtained on April 25, 1999. Vertical bars represent assumed error for discharge to drainage area ratio data. Indicated longwall panels have been mined. 
Flow increased from $\mathrm{J} 7$ to $\mathrm{J} 8$, and then stabilized for stations $\mathrm{J} 8, \mathrm{~J} 9$, and $\mathrm{J} 10$. A constant increase in conductivity shows that underflow within bedrock subsidence fractures over panel P39 apparently partially returned to the stream channel within the $\mathrm{J} 7$ to $\mathrm{J} 9$ stream section. Streamflow at $\mathrm{J} 10$ had apparently returned to its "normal" $Q: A_{\text {ratio }}$ value, similar to that at J1 to J4.

The field that contains $\mathrm{J} 1$ through $\mathrm{J} 8$ was very marshy and contained standing water. The soil in the stream banks along J2 through $\mathrm{J} 7$ contains a considerable amount of clay, which may have acted as an aquitard. The presence of the aquitard may have explained small fluctuations in conductivity and temperature for previous stations (J4-J7). Small amounts of shallow perched water entering the stream may have decreased conductivity and increased temperature.

\section{April 29, 1999 monitoring}

Five additional monitoring stations were added to Stream $\mathrm{J}$ for all measurement events following April $25^{\text {th }}$. Weirs were utilized for discharge measurement for stations $\mathrm{J} 2$ through $\mathrm{J} 10$ and stations $\mathrm{J} 11$ through $\mathrm{J} 15$ were measured with a flow meter. Both weirs at $\mathrm{J} 2$ and $\mathrm{J} 3$ were functioning properly at that time and were used as monitoring stations. Baseflow conditions were much lower than on April $25^{\text {th }}$.

Figure 31 shows a plot of the adjusted discharge: area ratio, conductivity, and temperature versus downstream distance along Stream J. Similar $Q: A_{\text {ratio }}$ 


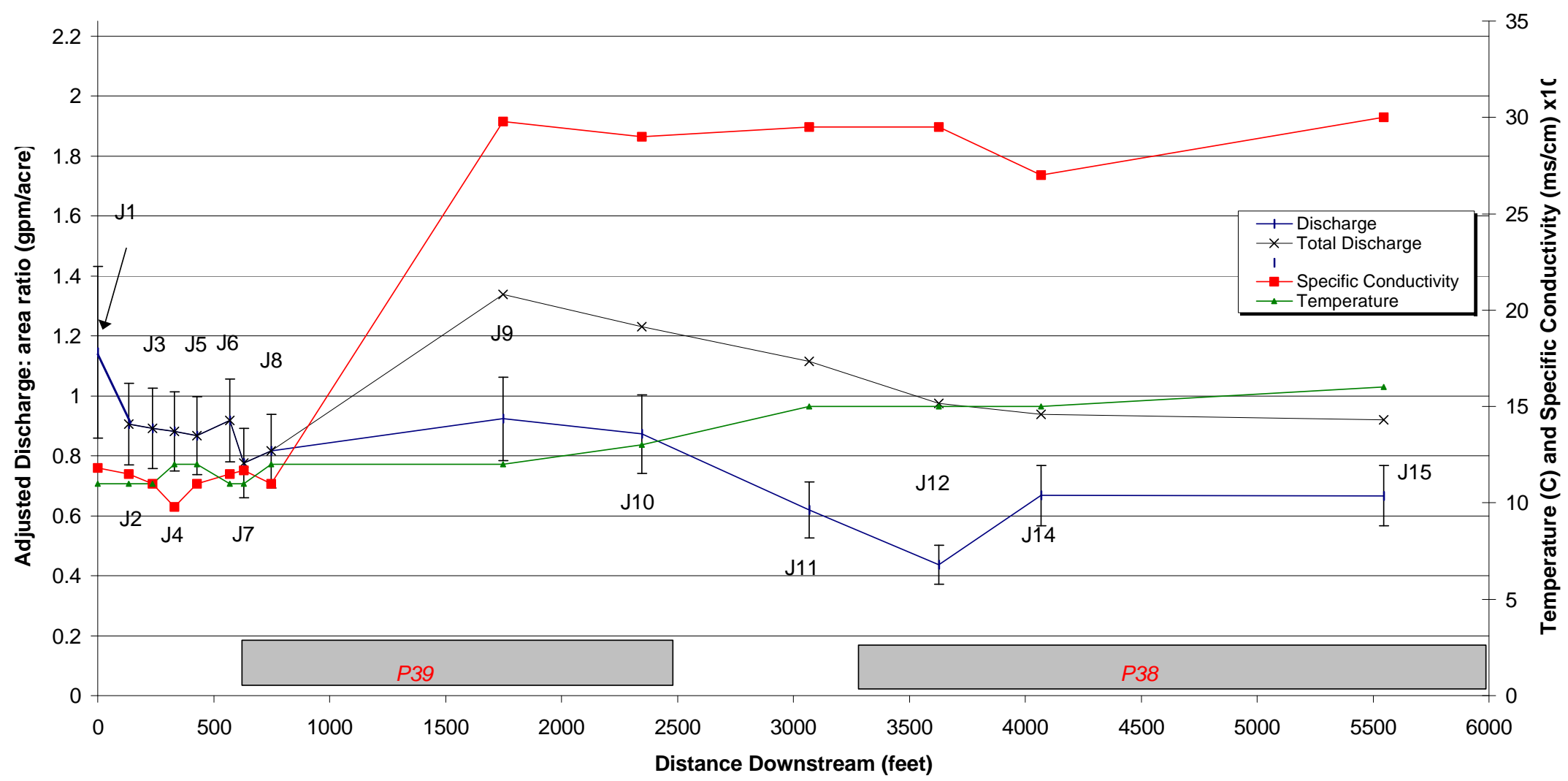

Figure 31. Plots of downstream distance along Stream $\mathrm{J}$ at Mine Z, versus adjusted discharge: area ratio, specific conductivity, and temperature, on April 29, 1999. Vertical bars represent assumed error for discharge to drainage area ratio data. Indicated longwall panels have been mined. 
trends are seen in both April $25^{\text {th }}$ and $29^{\text {th }}$ data. The $\mathrm{Q}: \mathrm{A}_{\text {ratio }}$ decreases steadily from $\mathrm{J} 1$ to $\mathrm{J} 7$, probably from the effects of subsidence fractures associated with panel P39. The $\mathrm{Q}: \mathrm{A}_{\text {ratio }}$ increase from $\mathrm{J} 5$ to $\mathrm{J} 6$ is within measurement error and not significant. Flow increases from $\mathrm{J} 7$ to $\mathrm{J} 8$, but not to the same level as on April $25^{\text {th }}$. Flow increases from $\mathrm{J} 7$ to $\mathrm{J} 9$, which is consistent with the April $25^{\text {th }}$ data trends. Similar trends in temperature and conductivity also occur on April $25^{\text {th }}$ and April $29^{\text {th }}$ for stations $\mathrm{J} 1$ through $\mathrm{J} 8$.

The $Q: A_{\text {ratio }}$ at $\mathrm{J} 11$ is lower than that of any upstream station and may result from dewatering in the subsidence tensional fracture zones of both panels P39 and P38. The angles of dewatering influence at station J11 for panels P39 and P38 are $15^{\circ}$ and $8^{\circ}$, respectively. The sections of panels P39 and P38 near station J11 were mined out in January 1999 and June 1998, respectively. The $\mathrm{Q}: \mathrm{A}_{\text {ratio }}$ continues to decrease at $\mathrm{J} 12$, but then increases and plateaus for $\mathrm{J} 14$ and J15. Since the J14 and J15 Q: $A_{\text {ratio }}$ are significantly less than those for J1 to J10, panel P38 is still impacting Stream J.

Specific conductivity is fairly consistent downstream after a large increase from $\mathrm{J} 8$ to $\mathrm{J9}$, suggesting no substantial underflow enters the channel down gradient of J9. Temperature also has a consistent increasing trend, which is thought to be caused by an increase in outside air temperature during the time spent monitoring Stream J from station J1 to J15. Alluvium thickness was not measured for Stream J. 


\section{May 21, 1999 monitoring}

The plot of the adjusted discharge: area ratio (Figure 32) for May $21^{\text {st }}$ shows small inconsistencies compared to previous events (Figures 30 and 31 ). The $\mathrm{Q}: \mathrm{A}_{\text {ratio }}$ increases slightly from $\mathrm{J} 3$ to $\mathrm{J} 4$, which is probably a result of measurement error. If $\mathrm{J} 3$ is disregarded, the $\mathrm{Q}: \mathrm{A}_{\text {ratio }}$ decreases from $\mathrm{J} 1$ to $\mathrm{J} 7$ and is consistent with the previous data.

At the time of the May $21^{\text {st }}$ event, Stream $\mathrm{J}$ was undergoing dredging along a section that included stations $\mathrm{J} 12$ and J14. Dredging was done by the Mine $Z$ company in an effort to improve drainage of a large field located in the subsidence trough created by panel P38. Dredging eliminated the amount of alluvial cover at these stations and may have actually had a negative impact on overall stream discharge. Exposing bedrock in the stream channel may have allowed water to travel in subsidence fractures that were previously sealed or covered by alluvium (Figure 33). The lack of alluvium may account for the decrease in flow seen from station $\mathrm{J} 10$ to station $\mathrm{J} 11, \mathrm{~J} 12$, and $\mathrm{J} 14$. The increase at $\mathrm{J} 15$ may be from the return of some underflow into the stream channel. The upstream dredging at J14 may have provided alluvium to station $\mathrm{J} 15$, causing thicker than normal alluvium at this station.

The conductivity trend is similar to previous Stream $\mathrm{J}$ data, except for the sharp increase from $\mathrm{J} 10$ to $\mathrm{J} 15$. The conductivity increase was probably from increased ground water discharge into the streambed between J14 and J15. The conductivity increase corresponds with a decrease in temperature for J14 to J15. 


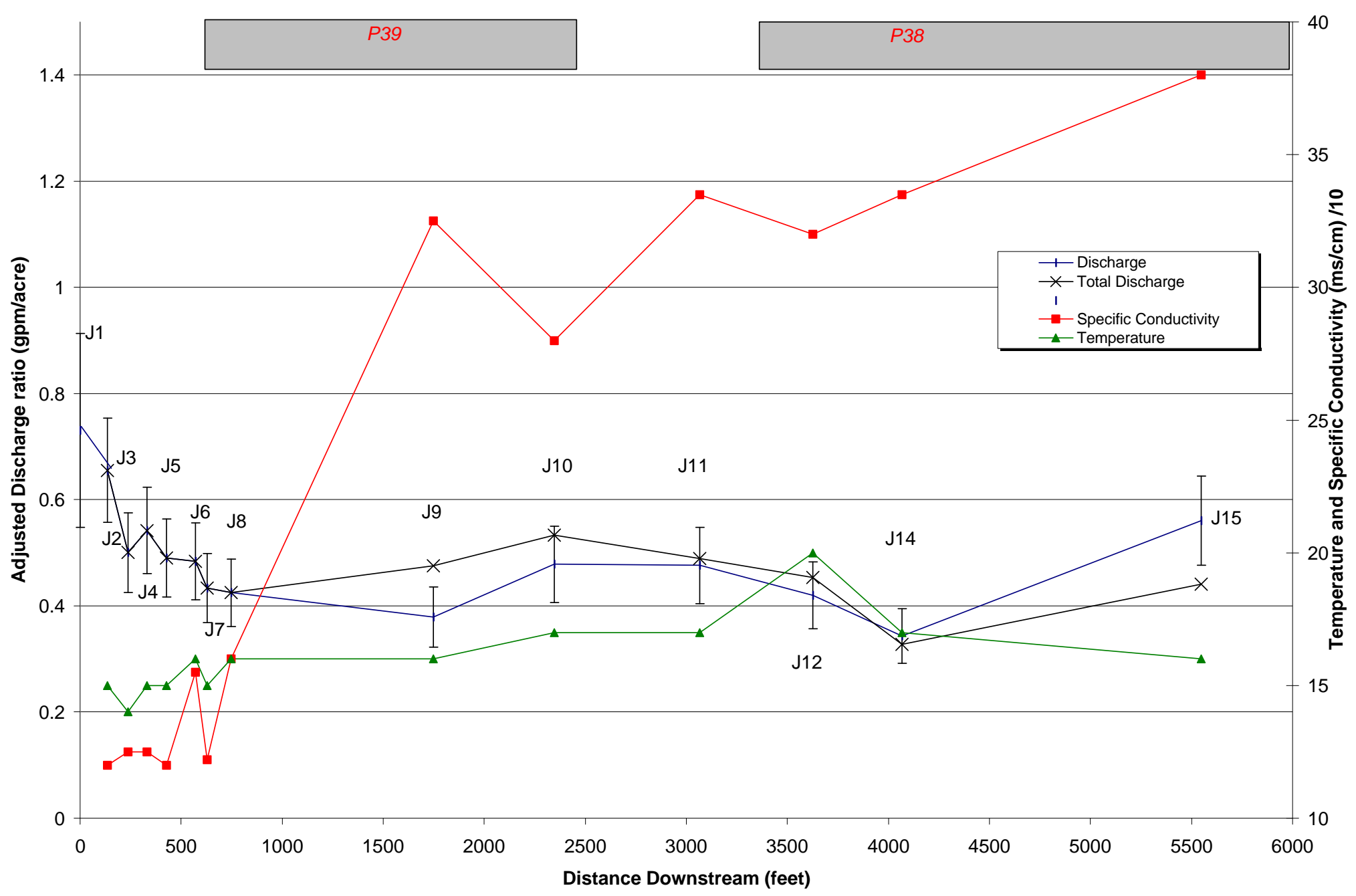

Figure 32. Plots of downstream distance along Stream J at Mine Z, versus adjusted discharge: area ratio, specific conductivity, and temperature, on May 21, 1999. Vertical bars represent assumed error for discharge to drainage ratio data. Indicated longwall panels have been mined. 


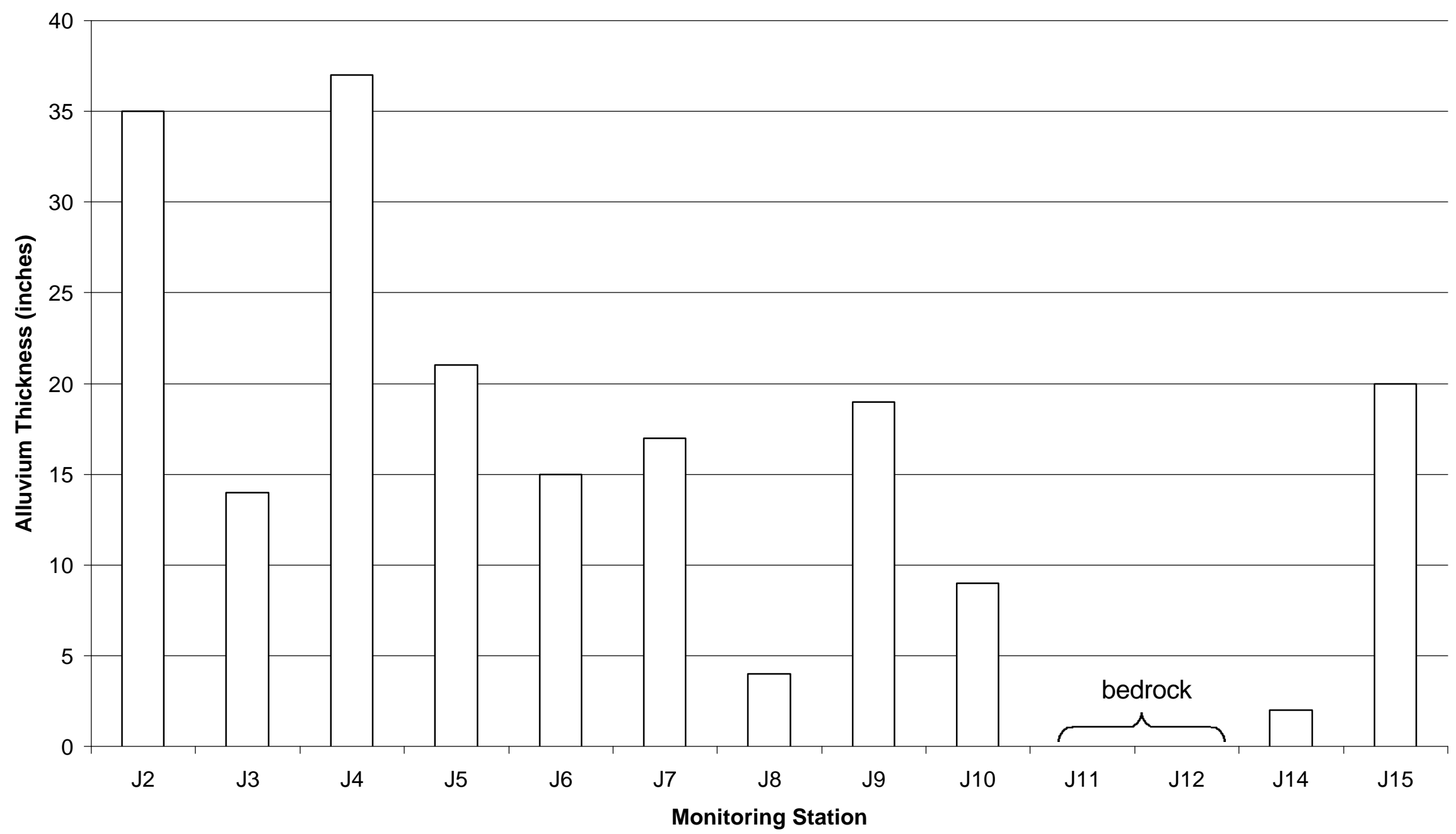

Figure 33. Alluvium thickness for Stream J at Mine Z. Data were collected on May 21, 1999. 


\section{June 16, 1999 monitoring}

At the time of the June $16^{\text {th }}$ stream-sampling event, panel P40 was mined out under the upstream section of Stream $\mathrm{J}$, which resulted in a dry stream reach from stations $\mathrm{J} 1$ through J8 (Figure 34). The likely cause of the dewatering impacts is the combined effects of recent P40 undermining with drought conditions. Flow first appears at the intersection of Stream $\mathrm{J}$ with a small tributary between stations $\mathrm{J} 8$ and J9. Flow increases downstream until J10, and then decreases at $\mathrm{J} 11$, the result of combined dewatering of panels P39 and P38. Flow increases from $\mathrm{J} 11$ to $\mathrm{J} 15$ where Stream $\mathrm{J}$ shows no negative impacts from panel P38.

\section{August 7, 1999 monitoring}

Few stations along Stream J experienced flow during August. Flow appears slightly upstream of $\mathrm{J} 11$, increases to $\mathrm{J} 12$, and continues at the same Q:A ratio to J15 (Figure 35). Conductivity increases from J11 to J14 and then decreases to J15. The conductivity increase can be related to the amount of bedrock in the stream channel at those stations. Water passing over exposed bedrock in the stream channel may induce rapid chemical weathering, releasing a large amount of dissolved solids into the water. 


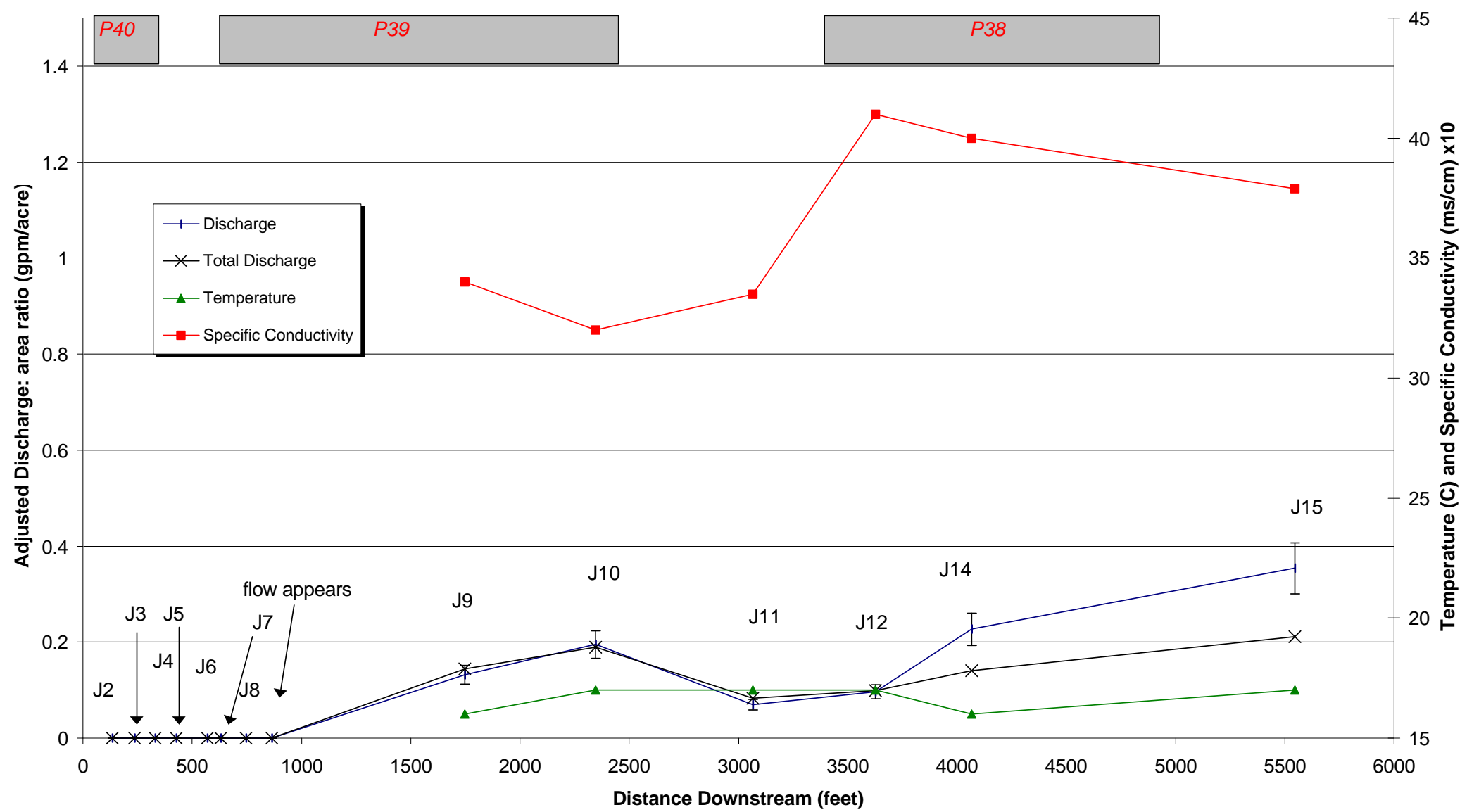

Figure 34. Plots of downstream distance along Stream $\mathrm{J}$ at Mine $Z$, versus adjusted discharge: area ratio, specific conductivity, and temperature, on June 16,1999. Vertical bars represent assumed error for discharge to drainage area ratio data. Indicated panels have been mined. 


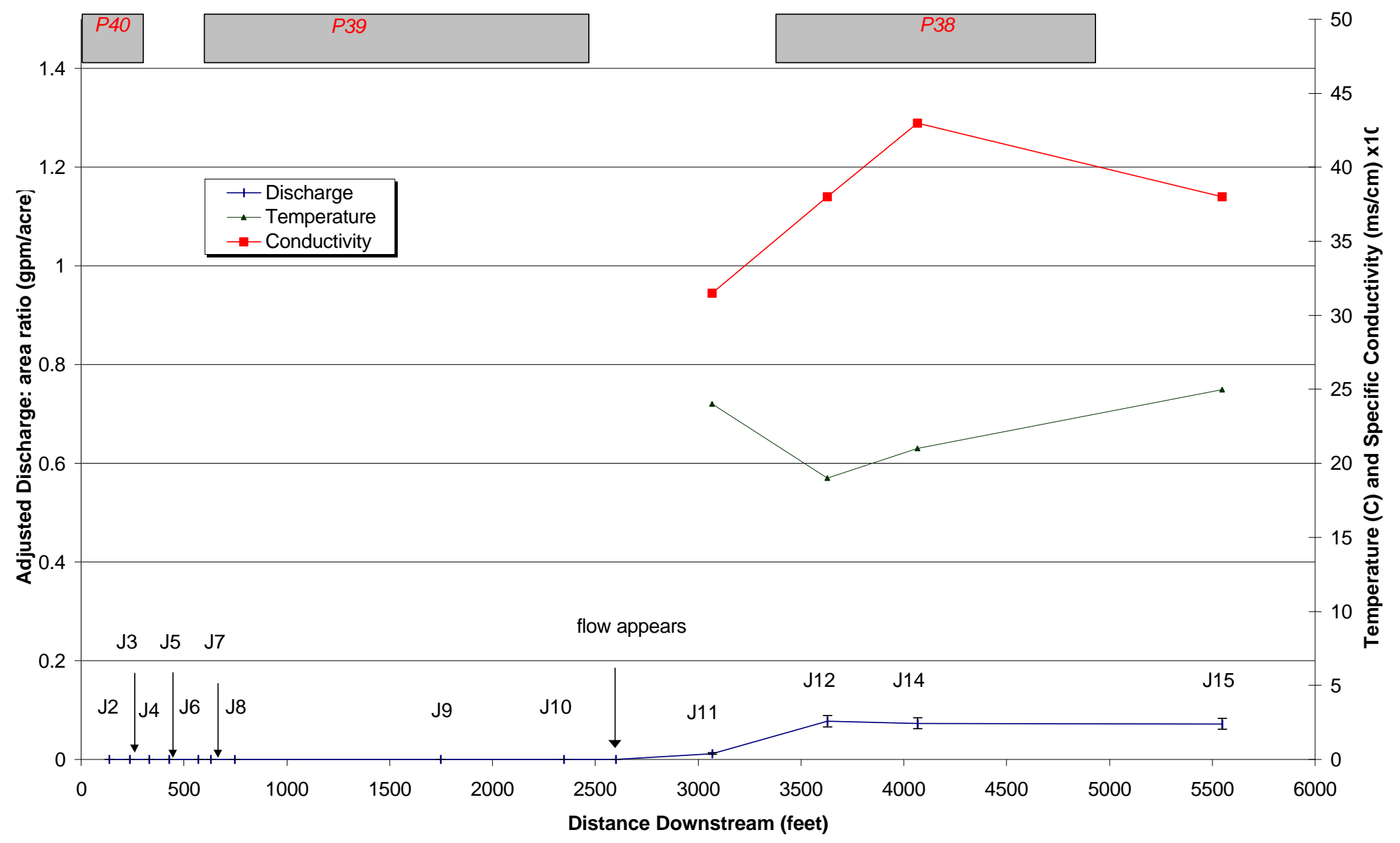

Figure 35. Plots of downstream distance along Stream $\mathrm{J}$ at Mine Z, versus adjusted discharge: area ratio, specific conductivity, and temperature, on August 7, 1999. Vertical bars represent assumed error for discharge to drainage area ratio data. Indicated longwall panels have been mined. 
Figure 36 shows the adjusted discharge: area ratios for all of the discharge events measured along Stream J, including Carver's data (1994). At the time of Carver's study of Mine Z, stream $\mathrm{J}$ was not undermined and was a control stream. Carver's data show that the $Q: A_{\text {ratio }}$ values for Stream J, before it was undermined, were very consistent, even though Carver had fewer sampling stations (five).

In conclusion, Stream J exhibits a pattern of mine subsidence related dewatering. Prior to the introduction of mined panel P40, panel P39 caused some initial dewatering from $\mathrm{J} 2$ to $\mathrm{J} 7$, as shown by the $4 / 25 / 99,4 / 29 / 99$, and 5/21/99 data sets. These plots show stabilized $Q: A_{\text {ratio }}$ values for stations downstream of J7. Station J11, J12, and J14 also showed streamflow loss to underflow associated with little or no stream alluvium there. After panel P40 was mined, the subsidence induced dewatering of Stream J headwaters was more severe. A comparison of 6/16/99 data with Carvers' 5/16/92 data reveals the extent of the subsidence impacts. 


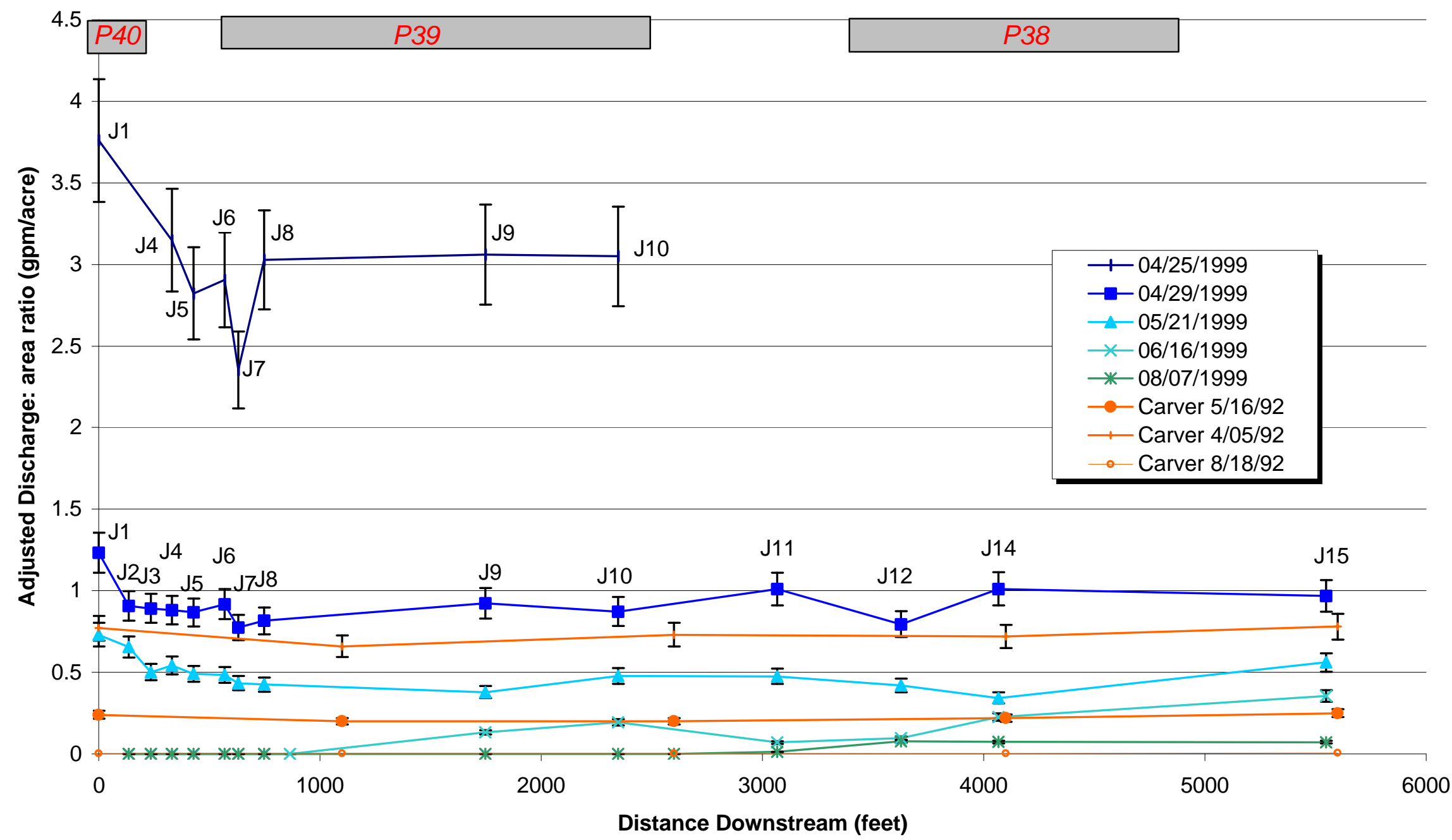

Figure 36. Comparison of all discharge data for Stream J at Mine Z. Indicated panels have been mined. Vertical bars represent assumed error for discharge to drainage area ratio data. All error bars are $+/-10 \%$ in order to consistently reflect probable measurement error in Q:Aratio values. Panel P40 was mined between 5/21/99 and 6/16/99. 


\section{Stream Analysis for Mine C}

\section{Stream Segment 1}

Dixon (1988) measured discharge on May 30, 1987, during her investigation of streams in the vicinity of Mine C (Figure 37B; Figure 4). Her data show an increase in $\mathrm{Q}: \mathrm{A}_{\text {ratio }}$ directly over the center section of the panels and a decrease in $Q: A_{\text {ratio }}$ between panels. For stations where $Q: A_{\text {ratio }}$ values were unusually high, Dixon (1988) suggested that subsidence fracturing increased the rate of ground water contribution. Dixon suggested that loss of discharge between panels was caused by a lack of ground water contribution to the stream at those points.

Dixon used a Pygmy current meter to measure stream velocity for determining stream discharge and on May 30, 1987, streamflow conditions were described as "high baseflow", but flow was less than 6 inches deep at each monitoring station. These conditions are not optimum for the use of this current meter (Dixon, 1988) and the amount of error for the discharge values on May 30, 1987 may have been greater than the 25 percent assigned by Dixon (1988).

Hence, trends shown on Figure 37 may possibly be distorted. Stream alluvium could have been distributed differently in 1987 and streamflows were about 10 to 15 times greater than flows measured in 1999.

Discharge, specific conductivity, and temperature measurements for this study were taken on June 11, 1999 for Stream Segment 1(Figure 37A). Trends in the discharge, when compared to data collected by Dixon, are quite different. 

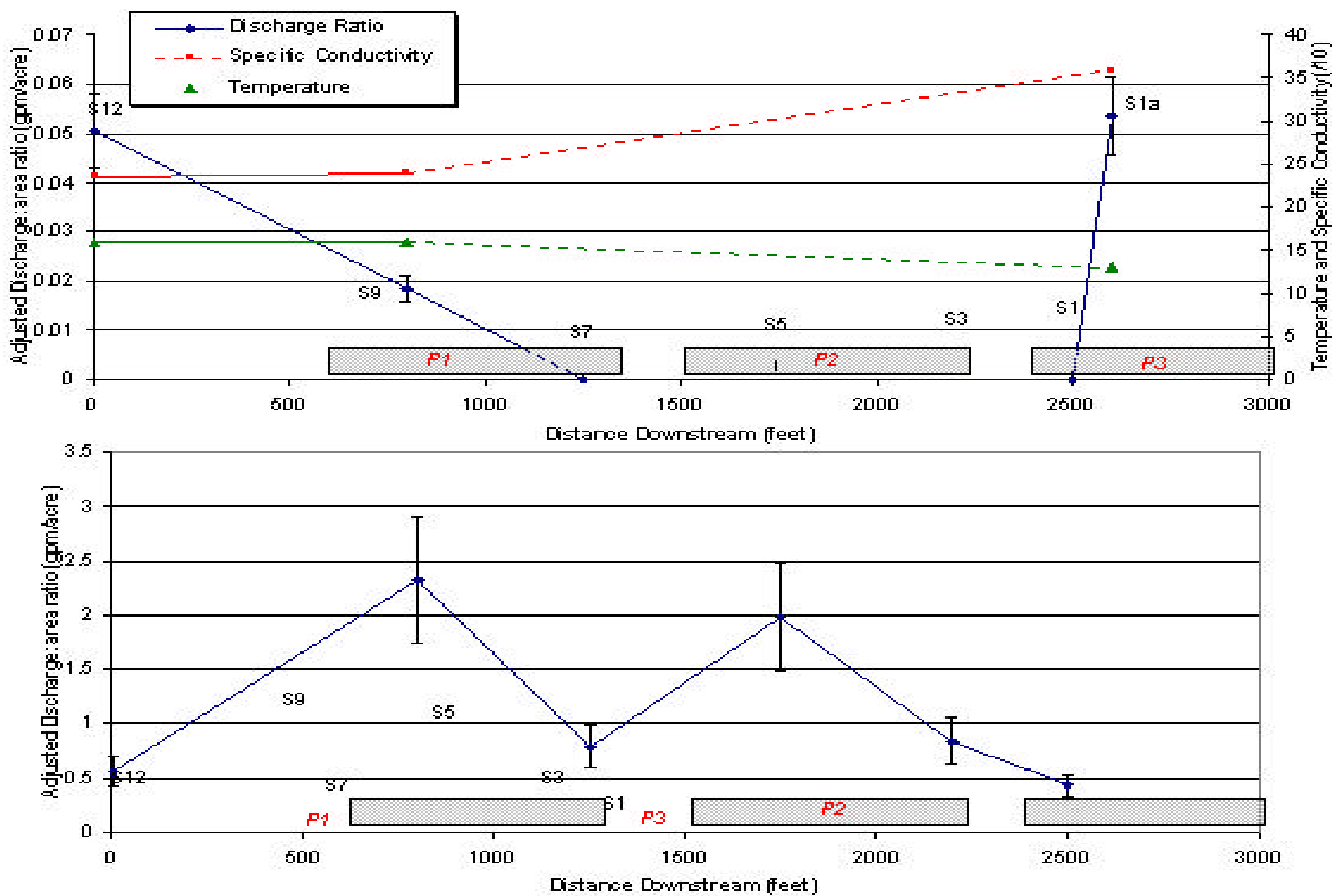

Figure 37. Plots of downstreath di stance for Stream Segment 1 at Mine $C$, versus $(A)$ acijusted di scharge: area $r$ atio, temperature, and conductivity as measured on June 11,1999 , and (B) adjusted discharge: area ratio comparison data from Dixon (1987). Vertical bars represent assum ed error for discharge to area ratio dat.a. Indicated ongwall panels have been mined. 
Stations S12 and S1a showed the highest Q: $A_{\text {ratio }}$ values. Discharge decreased steadily from $S 12$ to $S 9$, and then totally disappeared about 50 feet upstream of S7. Flow began to return to the streambed about 75 feet upstream of S1a, and at S1a stream discharge returned to normal. Station S1a was added in this study as a monitoring point because flow returned downstream from Dixon's original station S1. At the time of Dixon's investigation, backwash from Stream Segment 2 prevented further downstream monitoring.

Stations S12, S5, S3, and S1 had bedrock exposed in the streambed (Figure 38). Figure 39 shows bedrock (photo B) and subsidence fractures in bedrock (photo C) in the streambed near station S5. Photo A (Figure 39) shows a view looking downstream from a point located slightly upstream of monitoring station S1a, where a dramatic flow increase occurred.

The data (Figure 37A) suggest that stream dewatering from S12 to S7 was a result of undermined panel $\mathrm{P} 1$, combined with a lack of alluvium at $\mathrm{S} 12$. As water flowed downstream from $\mathrm{S} 12$, it was partially diverted through subsidence fractures in exposed bedrock, approximately 75 feet downstream of S12, and traveled downstream as underflow. The vertical angle for S12 with respect to panel $\mathrm{P} 1$ is $36^{\circ}$; this represents the maximum possible angle of dewatering influence for Mine C. Alluvium at S9 filled some of the subsidence fractures, allowing some streamflow to exit there, but by this point most water had already moved beneath the channel. Flow did not reappear until near S1a.

A possible explanation for the large increase in alluvium at S9 and S7 could be that, as water flowed downstream from S12 under high flow conditions, 


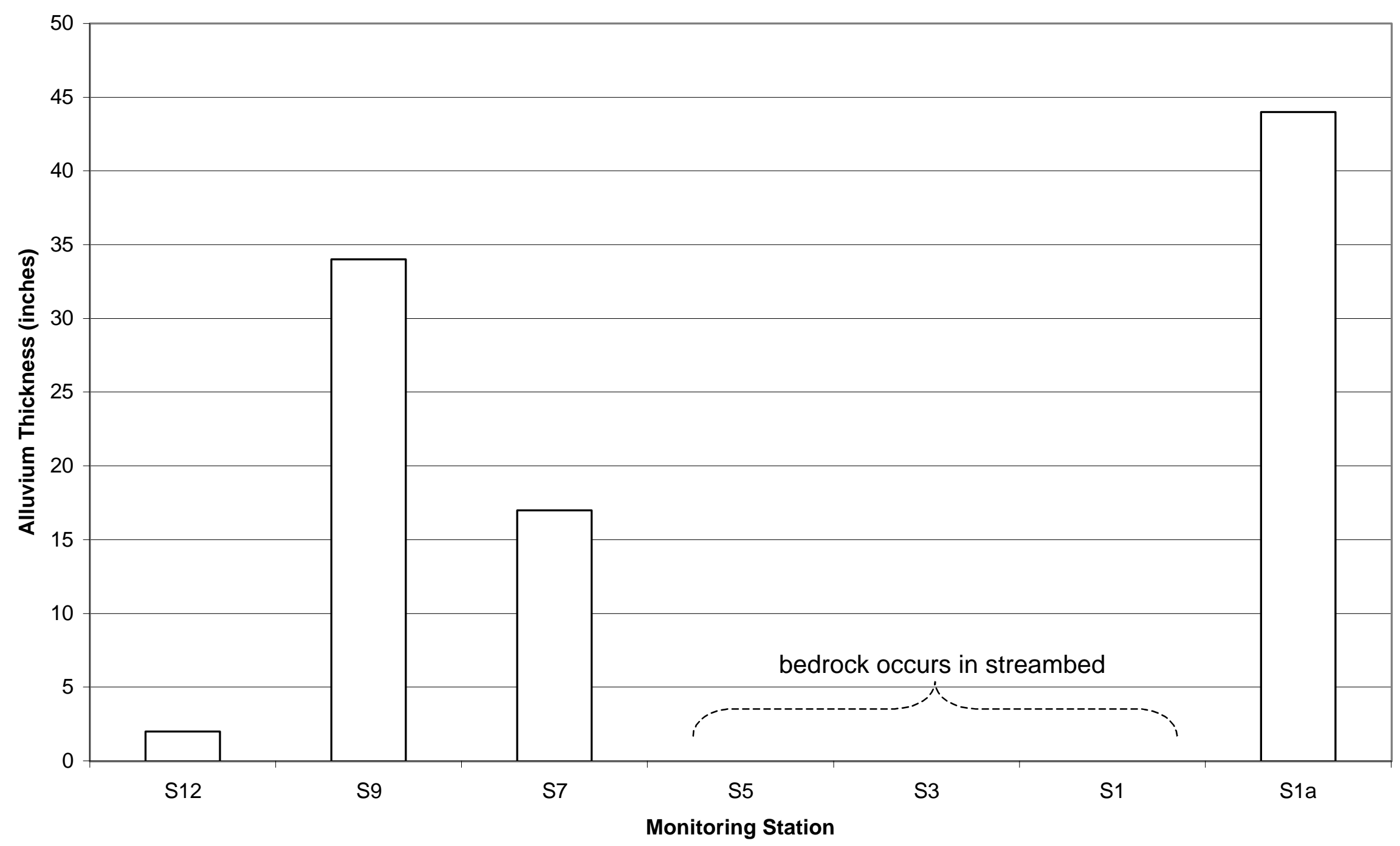

Figure 38 . Plot of the alluvium thickness for Stream Segment 1 at Mine C . Data were obtained on June 11, 1999. 

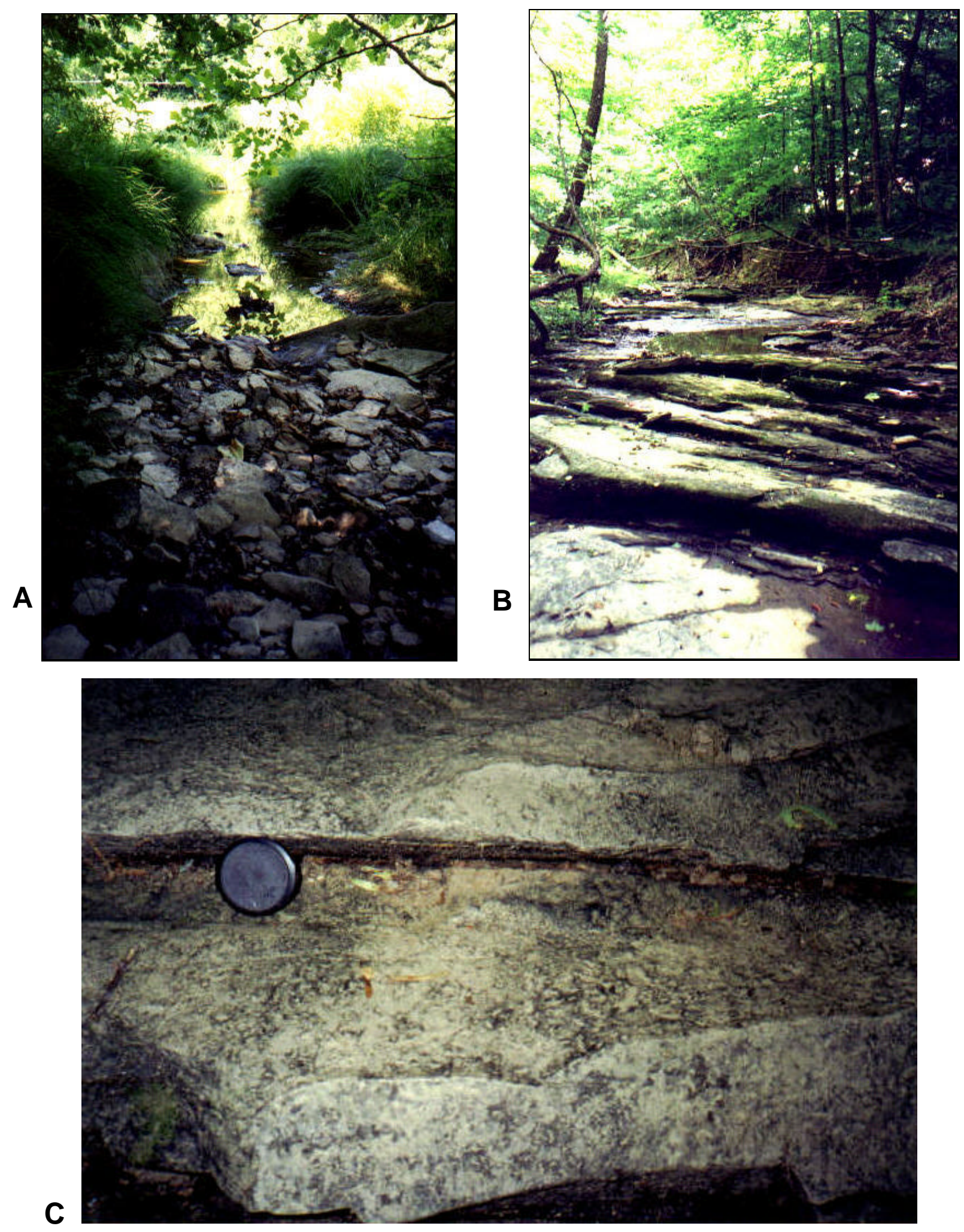

Figure 39. Photographs of Stream Segment 1 at Mine C, taken June 11, 1999. Photo A shows the return of stream water from discharging underflow near station $\mathrm{S} 1 \mathrm{a}$. Photo $\mathrm{B}$ shows a dry stretch of stream where bedrock is exposed in the streambed near station $\mathrm{S} 5$. Photo $\mathrm{C}$ shows subsidence fractures in the bedrock, also near station S5. 
some water was diverted into subsidence fractures. As more and more water flowed into subsidence fractures, the overall streamflow velocity decreased. With flow decreasing downstream, suspended load was deposited on the streambed. Another, and more likely, explanation is that flow velocity decreased because of a lower stream gradient caused by the subsidence trough created by mined panel P1, which allowed sediment to be deposited at S9 and S7.

Specific conductivity and temperature plots (Figure 37) provide more evidence of underflow. Before the flow disappeared near S7, the conductivity value is $240 \mu \mathrm{S} / \mathrm{cm}$. When the water reappeared at S1a, the value increased to $360 \mu \mathrm{S} / \mathrm{cm}$, suggesting fresh ground water discharged into the stream channel. The temperature decreased from $\mathrm{S} 9$ to $\mathrm{S} 1 \mathrm{a}$, also suggesting fresh ground water discharge. Flow returned to S1a, possibly because of a decrease in stream gradient and thick alluvium there.

\section{Stream Segment 2}

Dixon (1988) conducted discharge measurements along Stream Segment 2 at Mine C on November 17, 1987. Her study (Figure 40) suggested that panel P3 was negatively impacting stations S2-4 and S2-5. At that time, panel P3 had been mined out and subsided only 3 months prior. Monitoring stations S2-1, S22, and S2-3 were not impacted. Stream Segment 2 was monitored again on June 16, 1999 to observe any possible further mining impacts (Figure 40). 


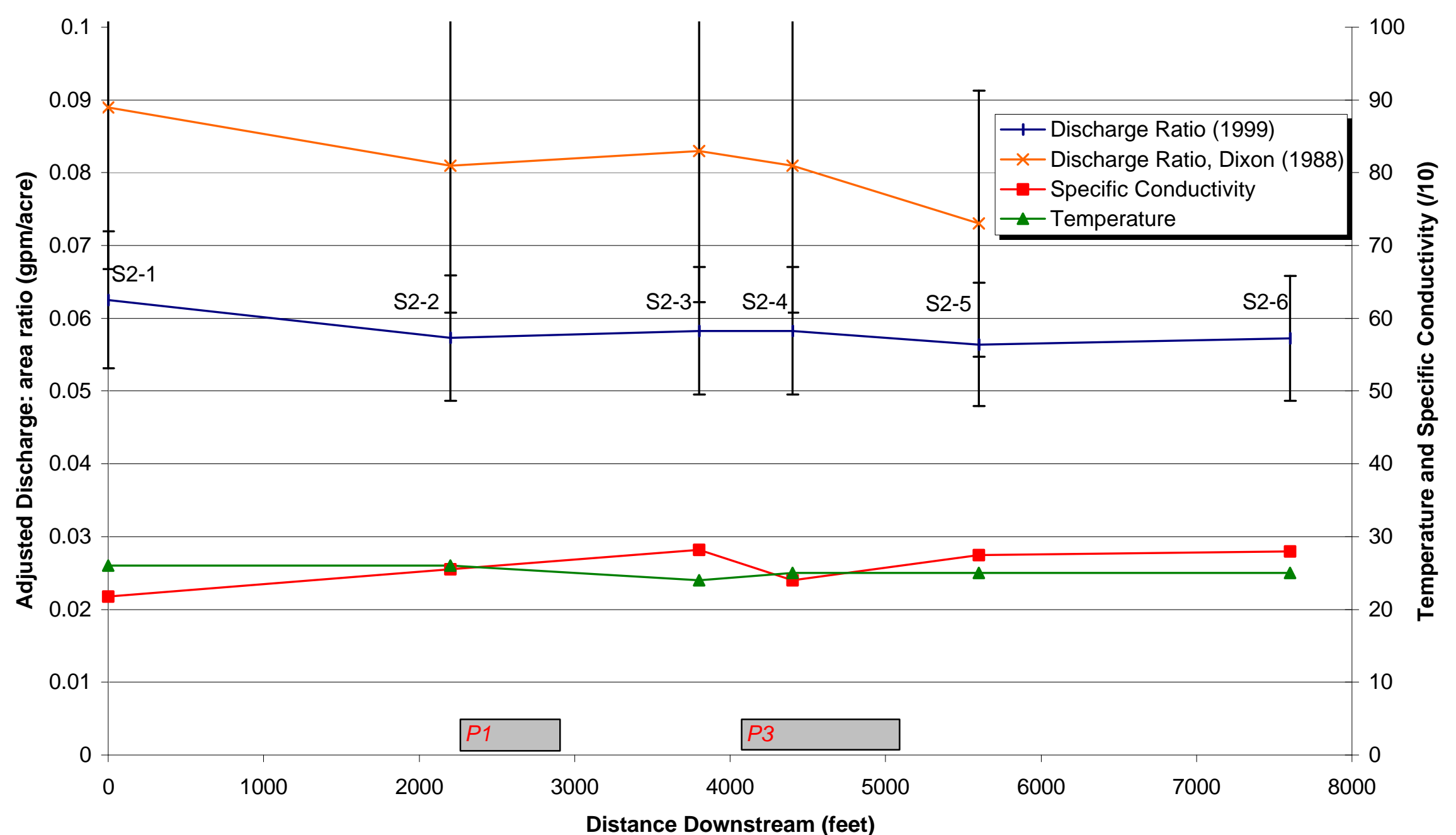

Figure 40. Plots of downstream distance for Stream Segment 2 at Mine C, versus adjusted discharge:area ratio. Data were obtained on June 16, 1999. Verticals bars represent assumed error for discharge to drainage area data. Indicated longwall panels have been mined. 
A decrease in $\mathrm{Q}: \mathrm{A}_{\text {ratio }}$ occurred from S2-1 to $\mathrm{S} 2-2$, but this was a nominal decrease, well within the 15 percent error bars, and does not necessarily indicate a mining impact. The remaining downstream stations show little in $Q: A_{\text {ratio }}$ variation from S2-2. This trend suggests mining impacts seen by Dixon (1988) no longer exist and that time has allowed subsidence fractures to heal in the area of S2-4 and S2-5. Panels P1, P2, and, P3 were mined out 13, 12.5, and, 11 years ago, respectively. 


\section{Stream Dredging}

One common drawback associated with longwall mining is the subsidence of the overburden rock and land surface above mined out areas. In an effort to restore streams to their previous uniform hydraulic gradient, the coal company at Mine $\mathrm{Z}$ has dredged portions of the floodplain stream channel between adjacent panels (Figure 41).

Figure $41 \mathrm{~A}$ shows an area that has not been undermined. The surface has a fairly uniform gradient from left to right, and the stream has no problems discharging water downstream. Figure 41B shows the same area after it was

undermined. Mined-out panels produce collapse in the overburden. The effects of the overburden collapse, in turn, produce a "surface subsidence trough" over each mined-out panel. As the stream passes from a high area between longwall panels to a subsided area overlying a panel, water ponds in the subsidence trough. Dredging is shown in Figure 41C. This technique is employed only to prevent ponding and is not intended to mitigate water losses from undermining. The process used for stream dredging is quite simple. First, an affected stream is selected and surveyed. From the survey, a longitudinal profile of the stream bottom elevation over horizontal distance is constructed. A negative slope line is then drawn on the profile to reflect what a reasonable stream gradient should be. This negative slope line should, theoretically, be a best-fit 

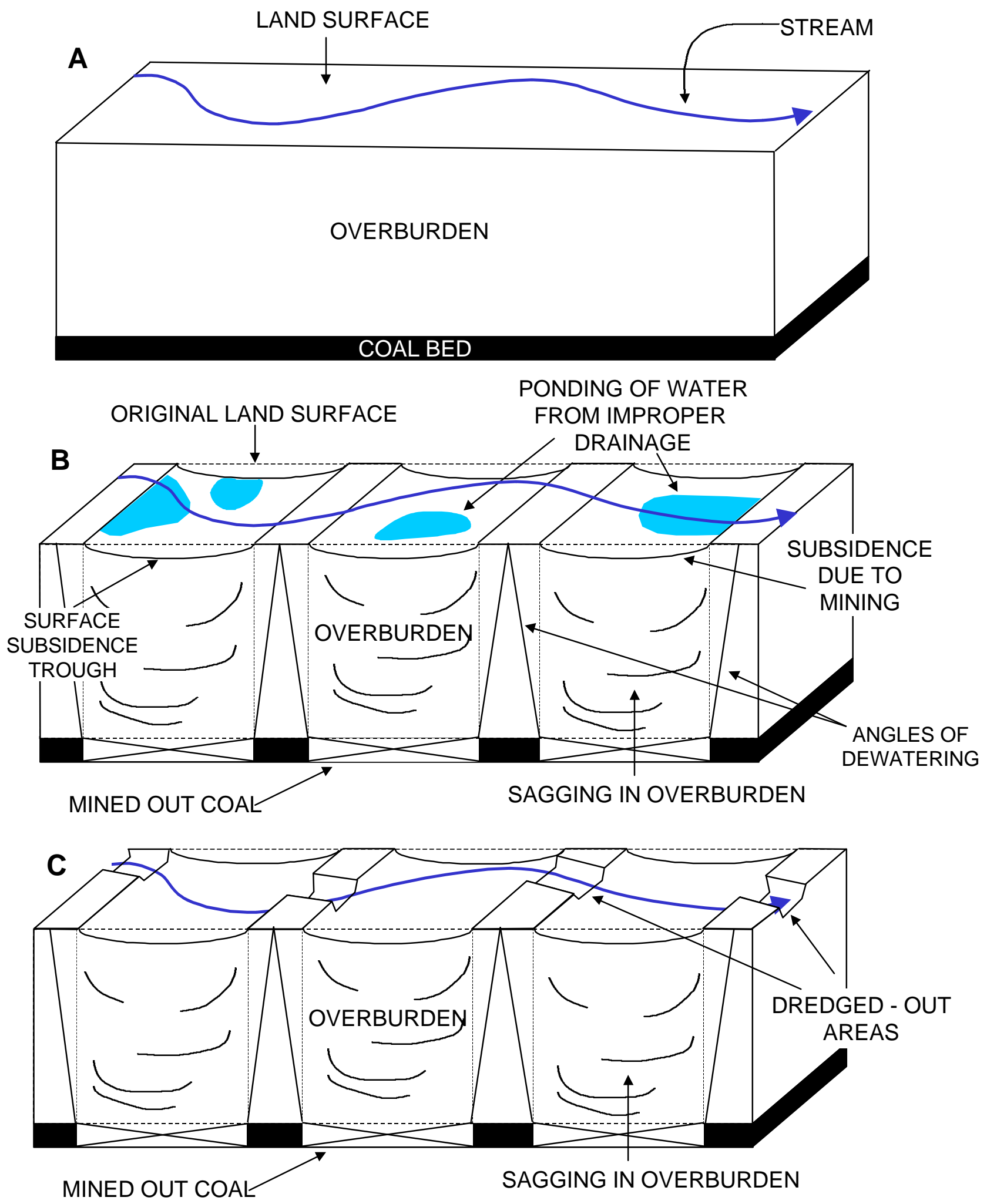

Figure 41. Schematic showing a stream and land surface previous to longwall mining impacts $(A)$, after mining impacts $(B)$, and after stream dredging $(\mathrm{C})$. 
line on the profile, one that will ensure drainage efficiency for the stream.

Backhoes are used to dredge out high spots along the stream (Figure 42, photo A).

Figures 43 and 44 show a segment of Stream SF that was profiled and dredged several times until the proper gradient and drainage was achieved. Although an optimum negative slope was not achieved for Stream SF, as evident on final profile line of 9/4/1996 (Figure 44), conditions were greatly improved. Figure 42B, shows a dredged section of Stream SF. For this section of the stream, excavators had to dig into shale bedrock, which was dumped on the stream banks.

Stream J was dredged from J12 to J14 during the summer of 1999 . This reach runs nearly parallel down the center of longwall panel P38 (Figure 29) and experienced approximately 5 feet of subsidence. Stream $\mathrm{J}$ was dredged to shale bedrock in the stream bottom at stations J12 and J14. Included, as part of the stream dredging, was trenching of a field near J12, which, before dredging, was constantly wet and marshy from water trapped in a subsidence trough. After dredging, drainage from the field was greatly improved.

Stream SF was dredged from SF7 to its northernmost contact with the Mine $Z$ boundary at panel P32. For the purpose of this study, only SF7 through SF13 were examined. Dredging did seem to have a positive effect on the nearby fields because flooding or ponding of water was not evident, although it should 

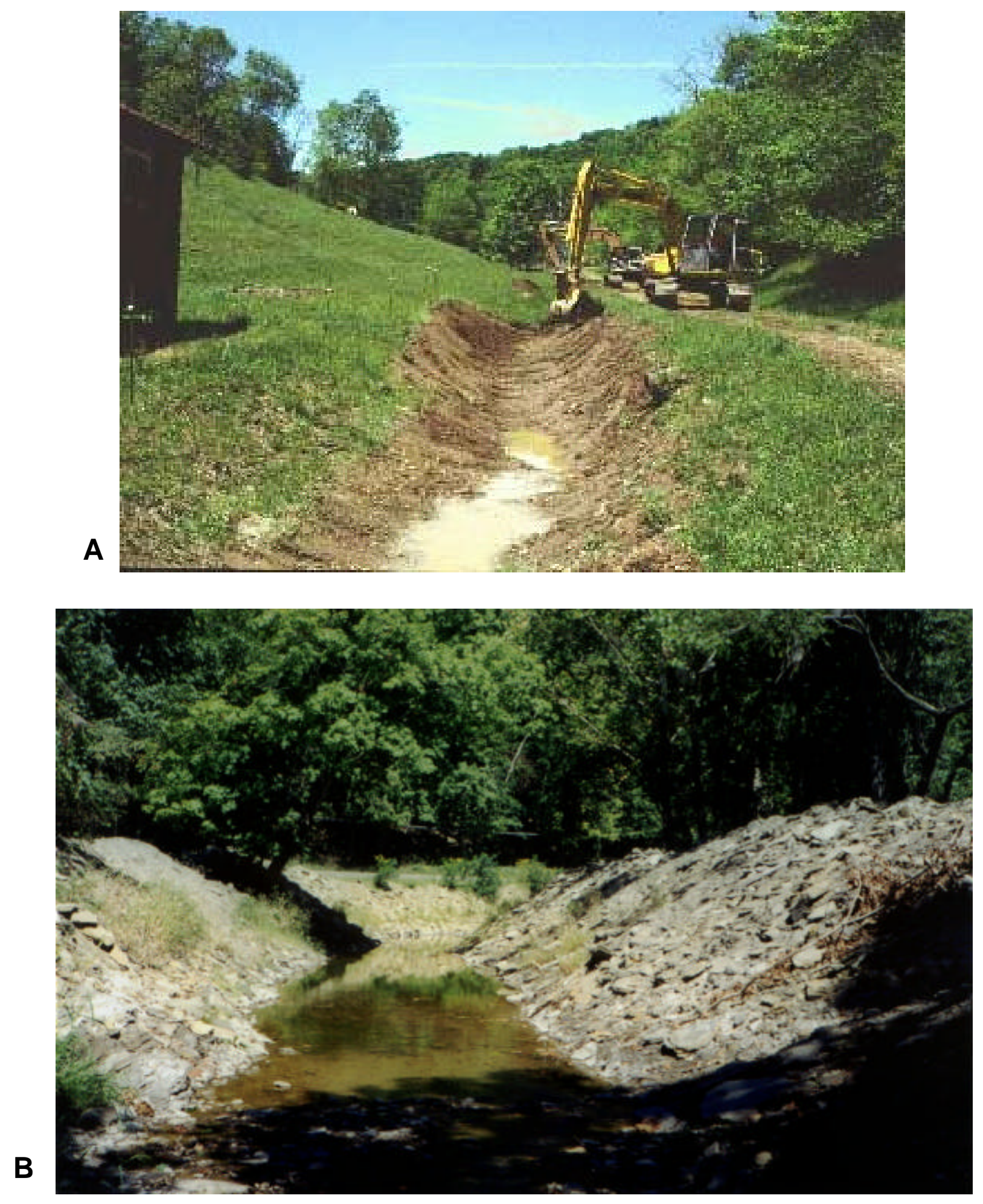

Figure 42. Stream dredging along two streams in the vicinity of Mine Z. Photo A shows active dredging along an undermined tributary of Stream J (5-21-99). Photo B shows completed dredging along Stream SF (7-26-99). 


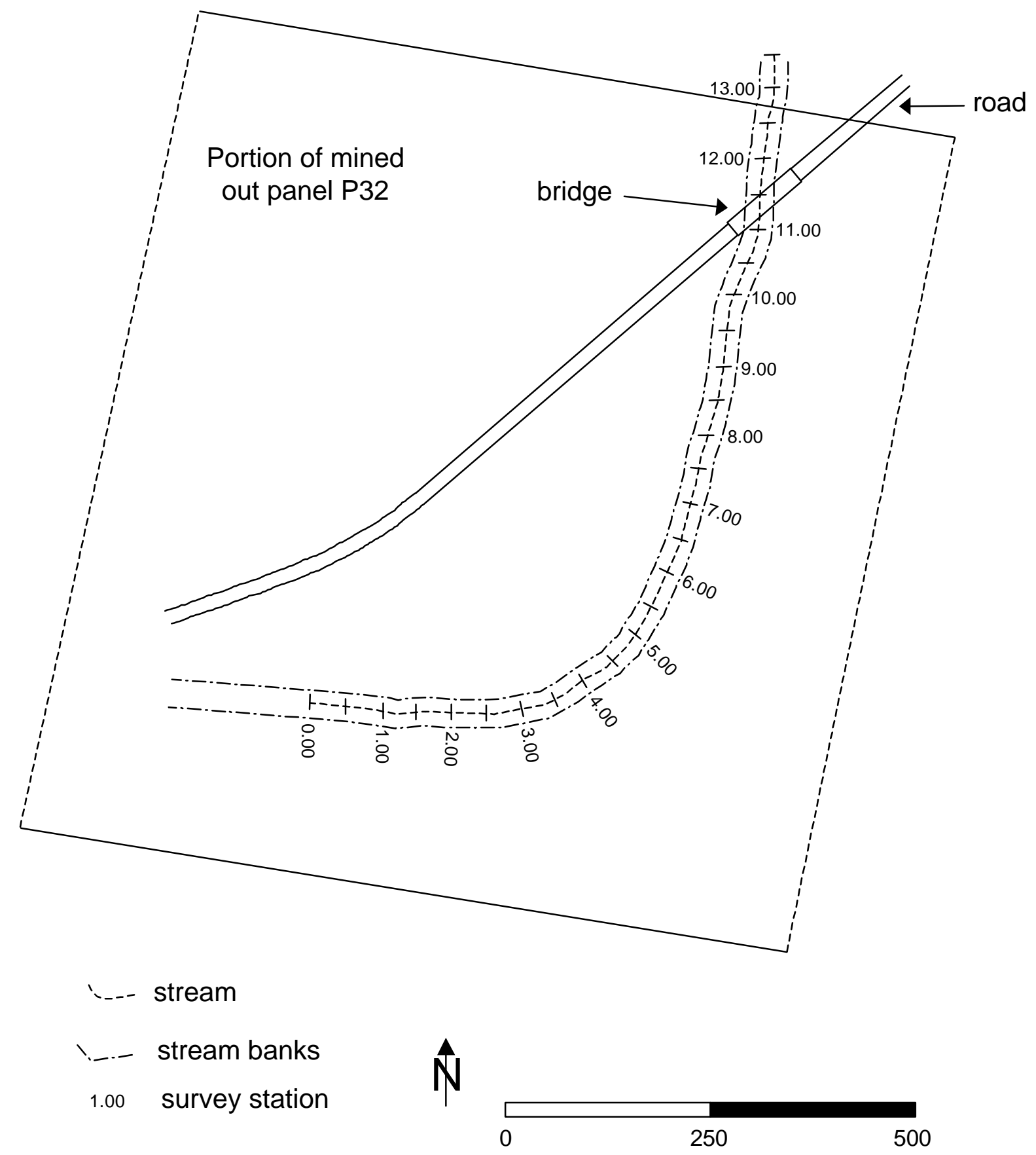

Figure 43. Excavation survey markers for stream dredging along Stream SF. 


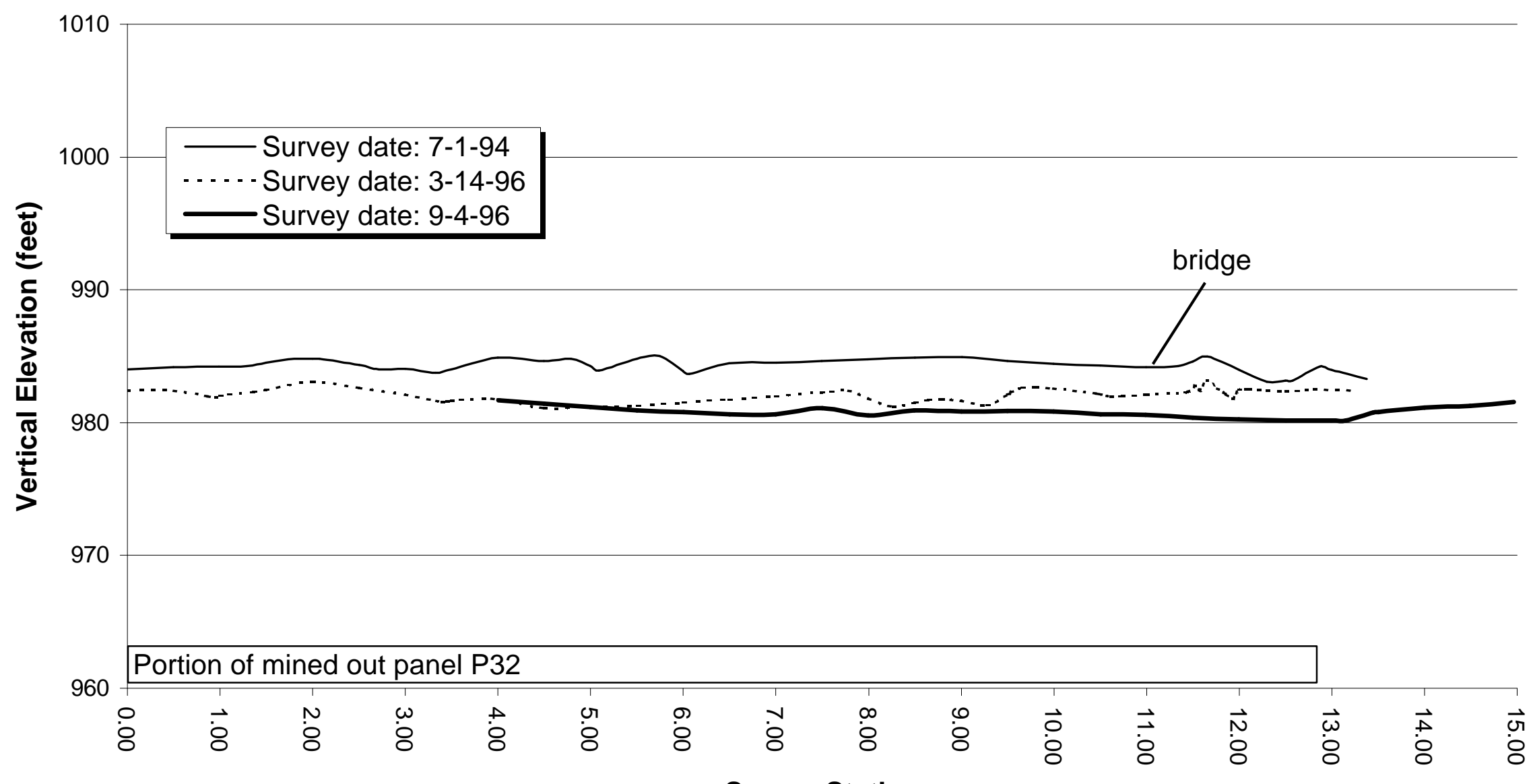

\section{Survey Station}

Figure 44. Profile lines for the stream bottom along Stream SF at Mine Z. Dredging was done to restore a negative slope to this stream bottom and to help prevent water from ponding, which commonly results from mine subsidence. This section of panel P32 was mined out during the month of July in 1994. This section of Stream SF was not monitored for discharge data or alluvium thickness. 
be noted that baseflow conditions were very low because of drought.

\section{Wolman Pebble Counting}

Wolman pebble counts were conducted along five selected streams in order to better understand the effect that alluvium particle size has on stream dewatering. A total of five streams were selected; three streams that showed signs of dewatering (Streams $\mathrm{J}$ and $\mathrm{K}$ at Mine Z, and Stream Segment 1 at Mine C) and two streams that did not (Streams $X$ and $Y$ at Mine $Z$ ).

Intermediate particle axes were measured with a nylon tape measure. Particles less than $1 \mathrm{~cm}$ in length were treated as silty sand. In areas where bedrock was exposed in the streambed, a value of $100 \mathrm{~cm}$ was substituted for a particle size diameter. Plots of the cumulative size percentage versus sediment size (phi) were prepared for each selected stream. The equation for phi units is (Folk, 1965):

$$
\text { phi }=-\log _{2} d_{m m}
$$

In an effort to simplify the analysis, all of the plots were divided into three size categories; large grains (greater than $-7 \mathrm{phi}$, or $>12.8 \mathrm{~cm}$ ), medium grains (between -7 and -3.3 phi, or 1.0 to $12.8 \mathrm{~cm}$ ), and small grains (less than -3.3 phi, or $<1.0 \mathrm{~cm})$. Table 2 gives the values of the median size for each sediment sample from both the impacted and non-impacted streams. 
Table 2. Alluvium size and thickness data for impacted and non-impacted streams at both Mine Z and Mine C.

Impacted Streams

Non-Impacted Streams

\begin{tabular}{llllll|llllll} 
Station & Median & $\mathrm{Al}$ & $\% \mathrm{~L}$ & $\% \mathrm{M}$ & $\% \mathrm{~S}$ & Station & Median & $\mathrm{Al}$ & $\% \mathrm{~L}$ & $\% \mathrm{M}$ & $\% \mathrm{~S}$ \\
\hline J8 & -3.3 & 4 & 16.5 & 36.3 & 46.2 & $\mathrm{X} 1$ & -4.8 & 15 & 9.9 & 57.1 & 33 \\
J9 & -5.2 & 19 & 3.3 & 67 & 29.7 & $\mathrm{X} 2$ & -5.9 & 14 & 13.2 & 73.6 & 13.2 \\
J10 & -3.9 & 9 & 9.9 & 47.2 & 42.9 & $\mathrm{X} 3$ & -4.1 & 10 & 6.6 & 52.8 & 40.6 \\
J11 & -10 & 0 & 66 & 0 & 33 & $\mathrm{X} 4$ & -10 & 0 & 59.4 & 20.8 & 19.8 \\
J12 & -10 & 0 & 57 & 6.6 & 36.3 & $\mathrm{X} 5$ & -4.7 & 2 & 3.3 & 53.8 & 42.9 \\
J14 & -1 & 2 & 0 & 3.3 & 95.7 & & & & & & \\
J15 & -5.4 & 20 & 0 & 92.4 & 6.6 & & & & & & \\
S12 & -10 & 2 & 57.1 & 33 & 9.9 & $\mathrm{Y} 1$ & -5.8 & 16 & 0 & 85.9 & 13.2 \\
S9 & -5.4 & 34 & 9.9 & 65.4 & 27.4 & $\mathrm{Y} 2$ & -5.7 & 36 & 0 & 89.1 & 9.9 \\
S7 & -5.7 & 17 & 6.6 & 93.4 & 0 & $\mathrm{Y3}$ & -6.2 & 7 & 36.3 & 37.3 & 26.4 \\
S5 & -10 & 0 & 83 & 17 & 0 & $\mathrm{Y} 4$ & -10 & 0 & 85.8 & 0 & 13.2 \\
S3 & -10 & 0 & 99 & 0 & 0 & $\mathrm{Y} 5$ & -3.7 & 27 & 0 & 52.8 & 46.2 \\
S1 & -10 & 0 & 90.1 & 9.9 & 0 & $\mathrm{Y} 6$ & -6.1 & 23 & 3.3 & 80.2 & 16.5 \\
S1a & -6.1 & 44 & 0 & 89.1 & 9.9 & $\mathrm{Y} 7$ & -1 & 20 & 0 & 0 & 99 \\
K8 & -1 & 14 & 0 & 0 & 99 & & & & & & \\
K4 & -10 & 6 & 75.9 & 16.5 & 6.6 & & & & & &
\end{tabular}

Key: Median = median sediment size $($ phi) based on cumulative size percent charts, $\quad \mathrm{Al}=$ alluvium thickness (inches), $\% \mathrm{~L}=$ percent of sample from -10 to $-7 \mathrm{phi}, \% \mathrm{M}=$ percent of sample from -7 to -3.3 phi, $\% \mathrm{~S}=$ percent of sample from -3.3 to 0 phi. 


\section{Stream J}

Pebble counts could only be conducted along Stream J for stations J8 through $\mathrm{J} 15$ because the weirs installed at the upstream most stations affected the stream sediment texture. Large amounts of sandy-silt accumulated on the upstream end of weirs and large boulders were exposed by erosion on the downstream end. Since these were not natural conditions for the stream, bedload measurements could not be conducted at those points.

Figure 45 shows the cumulative size plots of the Wolman pebble counts conducted for Stream J at Mine Z. Stations J8, J9, J10, and J15 yielded sediment samples that were relatively well sorted (with a high percentage of medium sized sediment), compared to those from J11, J12, and J14. The cumulative frequency plots for locations with stream dewatering $(\mathrm{J} 11, \mathrm{~J} 12$, and J14) prior to August 1999 show similar trends. The stream bed at J11 is 60 percent bedrock with some silt. Similarly, the bed at J12 contains about 60 percent bedrock, with most of the remaining 40 percent consisting of sandy silt. Station $\mathrm{J14}$, which shows slight dewatering impacts for a few sampling dates, has a very low amount of medium-sized particles in the streambed. The lack of alluvium and lack of medium-sized particles at these stations appear to have contributed to water losses. 
J8

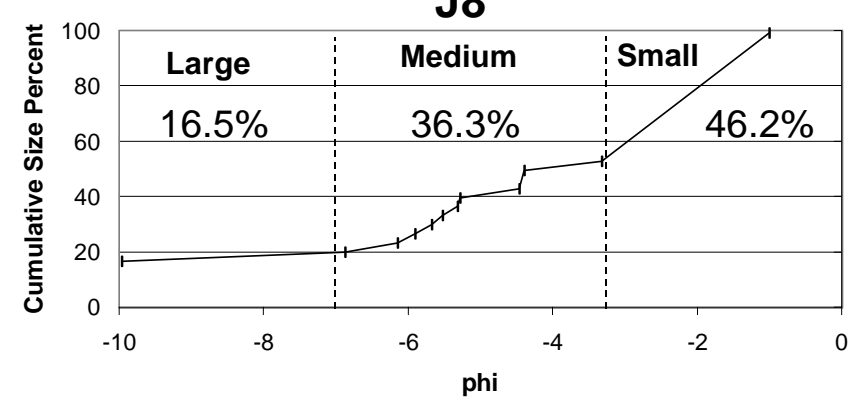

J10

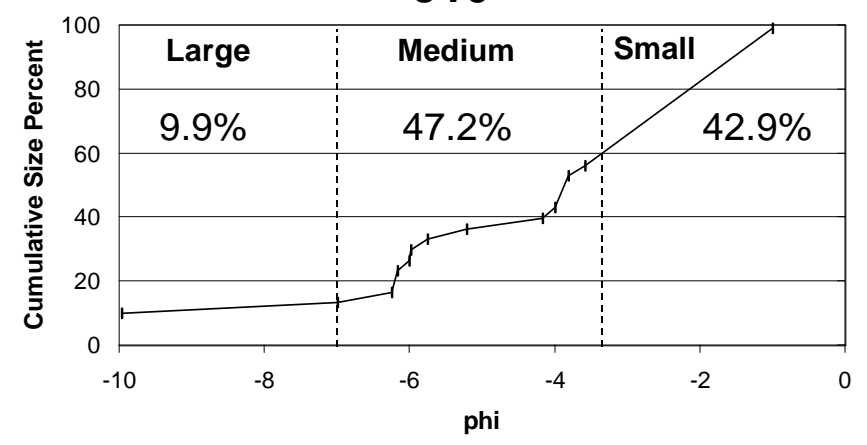

J12

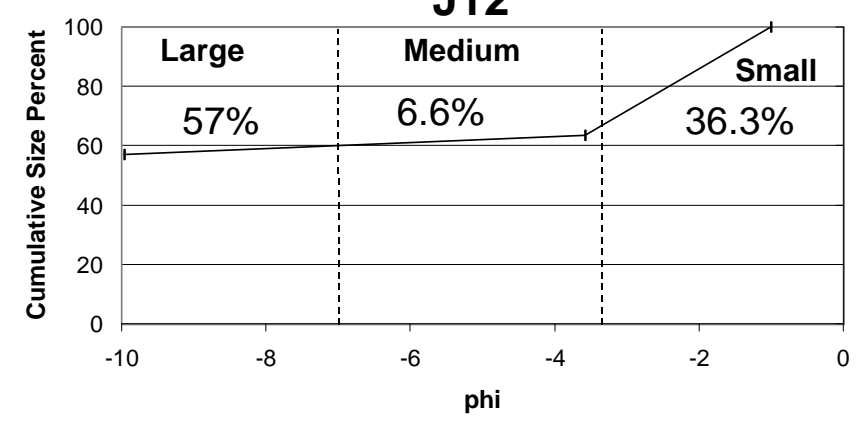

J9

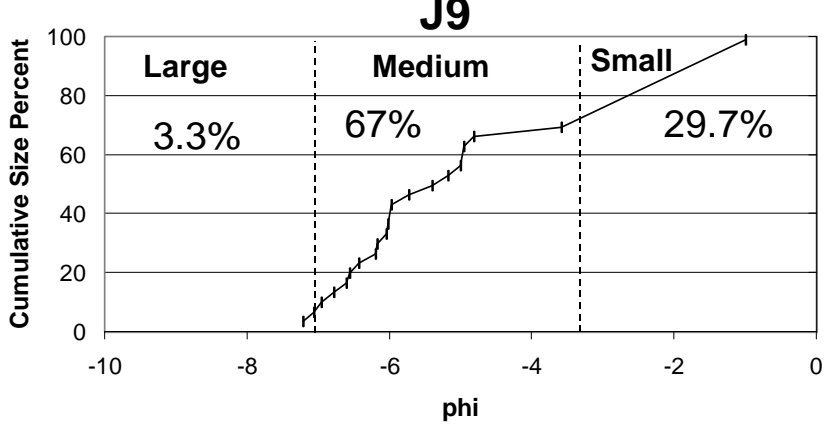

J11

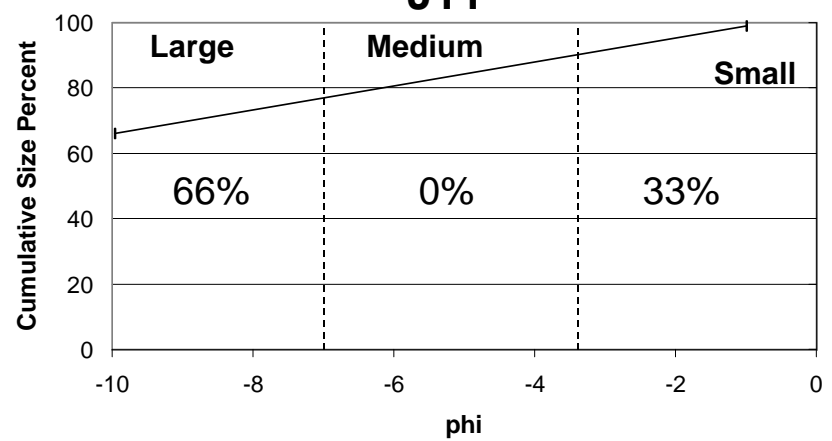

J14

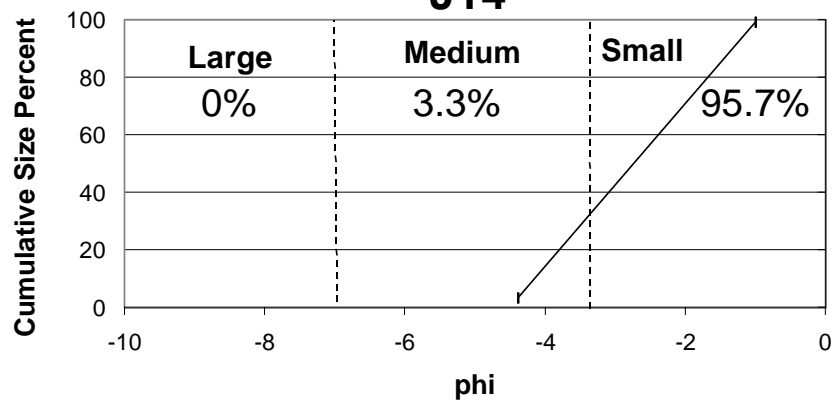

\section{J15}

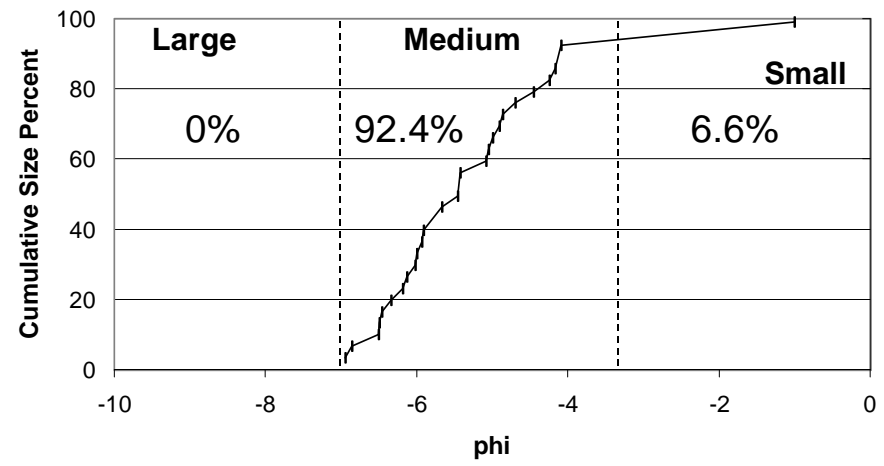

Figure 45. Wollman Pebble Count results for Stream J at Mine Z. Cumulative frequency plot of cumulative percentage versus sediment particle size (phi units). Data were obtained on August 11, 1999. 


\section{Stream K}

Stream K showed signs of dewatering at stations K4, K10, and K9. The cumulative percentage plot for K4 (Figure 46) shows that the streambed mostly consists of large particles, with bedrock being the modal streambed type. The channel at station K4 has only about six inches of alluvium. The lack of smaller sized particles (-6 phi to -2 phi), coupled with the lack of alluvium may be a factor in the slight stream loss at those stations. Conversely, $\mathrm{K} 10$ has a median of -1 phi (sandy silt), but this section has only about five inches of alluvium and lacks substantial medium-sized material. The trend for $\mathrm{K} 9$ is very similar to that of $\mathrm{K} 4$ and is, therefore, thought to account for similar dewatering results; as with the stations at Stream J, a lack of thick alluvium, combined with poorly sorted sediment that lacks medium sized particles, appears to aid in stream dewatering.

\section{Stream Segment 1 (Mine C)}

Dewatering along Stream Segment 1 is most pronounced at S7, S5, S3, and S1 (Figure 37). Sediment samples for stations S9, S7, and S1a are relatively well sorted with high percentages of medium-sized particles, but samples S12, S5, S3, and S1 are not (Figure 47). When the dewatering trend is compared to the cumulative size curves for the same stream, a familiar pattern is seen. Stations with the most dewatering, except for station S7, have thin (less than three inches) alluvium and are characterized by poorly sorted sediments. Stations with thick alluvium have better sorted sediments (more medium-sized particles). 
K8

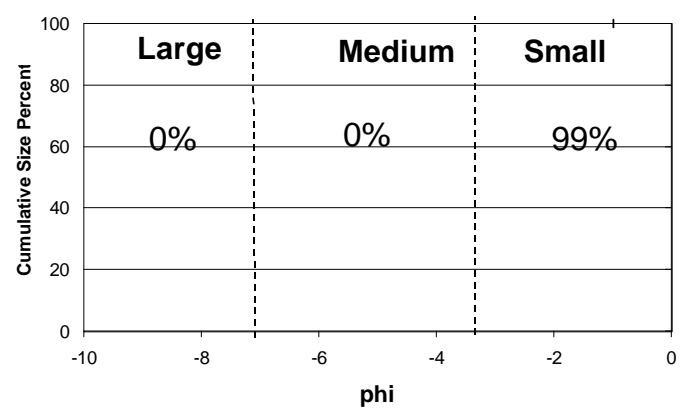

K10

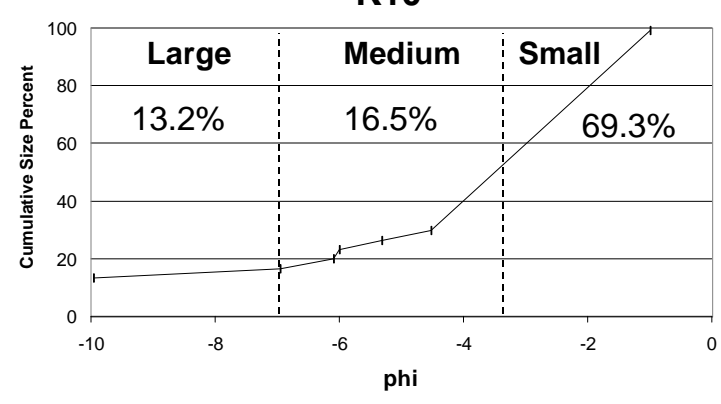

K4

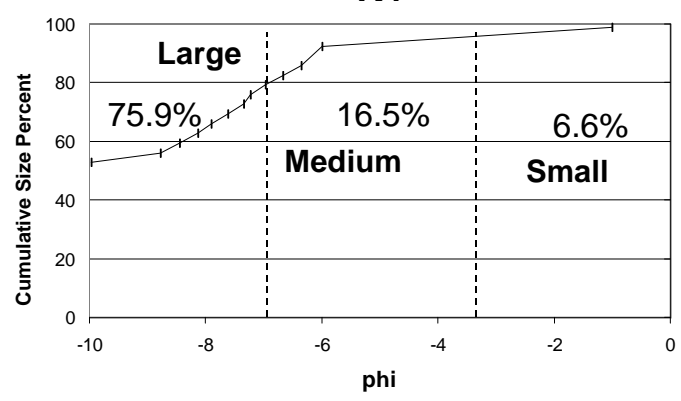

K9

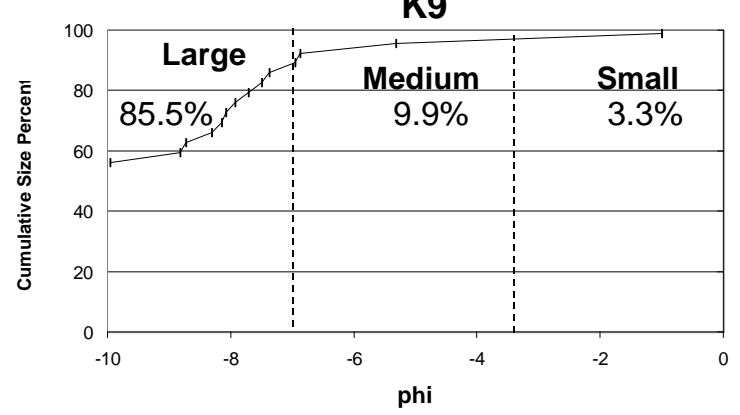

K1

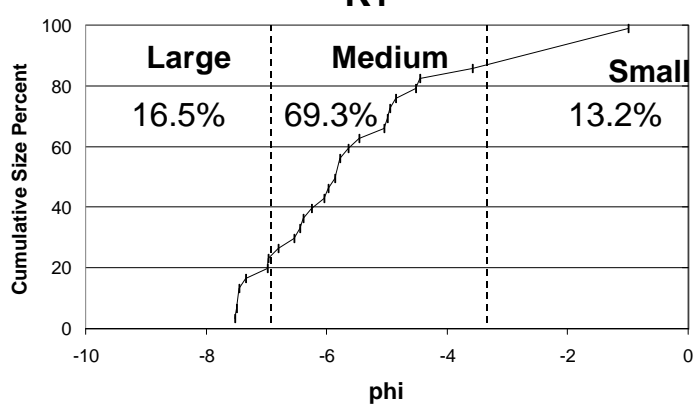

Figure 46. Wollman Pebble Count results for Stream K at Mine Z. Cumulative frequency plot of cumulative percentage versus sediment particle size (phi units). Data were obtained on August 18, 1999. 
S12

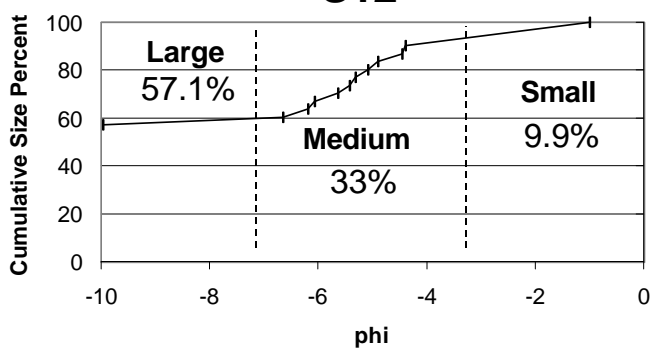

S7

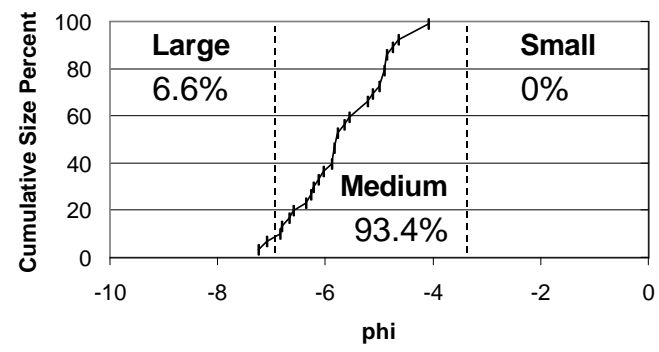

S3

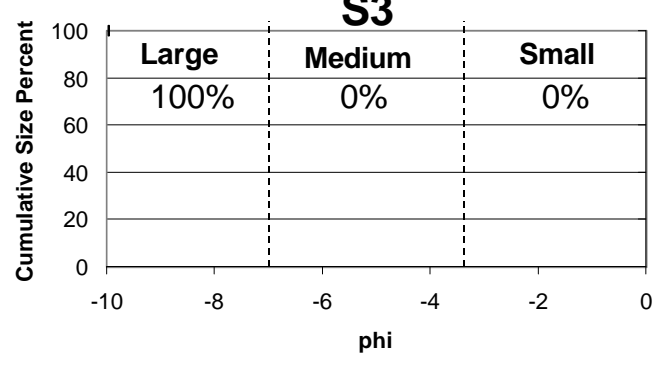

S9

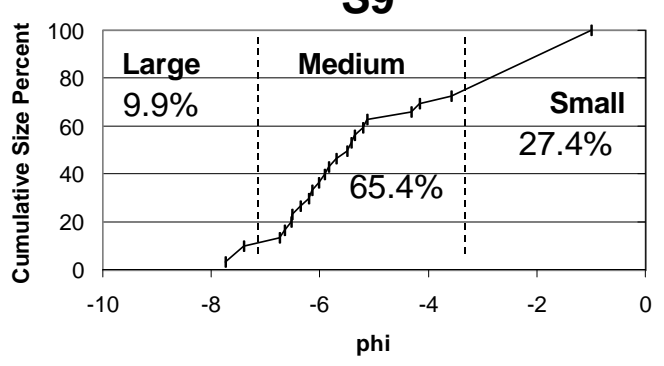

S5

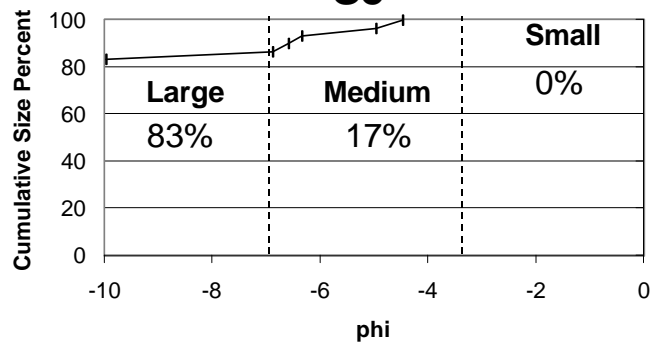

S1

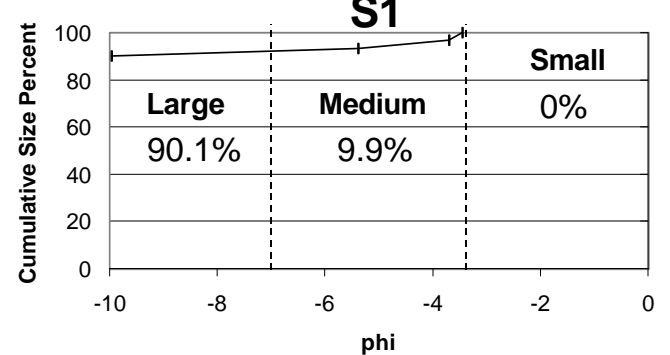

Figure 47. Wollman Pebble Count results for Stream Segment 1 at Mine C. Cumulative frequency plot of cumulative percentage versus sediment particle size (phi units). Data were obtained on August 11, 1999. 
The stream bed at station $\mathrm{S} 12$ consists of about 60 percent bedrock, with the remaining substrate consisting of medium-sized particles and sandy silt. Both S9 and S7 are well sorted (65\% and 93\% medium grained, respectively) and have considerable alluvium of over 17 inches (Figure 38), but these characteristics have not prevented dewatering. Perhaps the total lack of fine sediments at S7 prevented proper sealing of subsidence fractures there. Flow does not reappear until S1a. Bedrock is exposed in the streambed at S5, S3, and S1, where subsidence fractures are clearly evident.

Flow returns to the stream channel at $\mathrm{S} 1 \mathrm{a}$, where the sediment is well sorted with a median of -6.1 phi $(7 \mathrm{~cm})$. Water returns to $S 1 \mathrm{a}$, possibly because of a large increase in alluvium thickness, the presence of well-sorted sediment (89\% medium grained), and/or a decrease in stream gradient.

\section{Streams $X$ and $Y$}

Both control Streams, $\mathrm{X}$ and $\mathrm{Y}$, are positioned over non-undermined areas and show no significant downstream $Q: A_{\text {ratio }}$ fluctuations. Sediments at $Y 1, Y 2$, Y5, and Y6 are relatively well sorted (Figure 48). The channel at Y4 has poorly sorted sediments and consists of mostly bedrock, but shows no signs of dewatering. Station $\mathrm{Y7}$ does not show any signs of stream dewatering and has a bed composed entirely of sandy silt. The only station that has poorly sorted sediment along Stream X (X4) does not show any signs of dewatering (Figure 49). The lack of dewatering at stations $X 4, Y 4$, and $Y 7$ further indicates that no non-undermining factor has caused dewatering there, or has acted to 

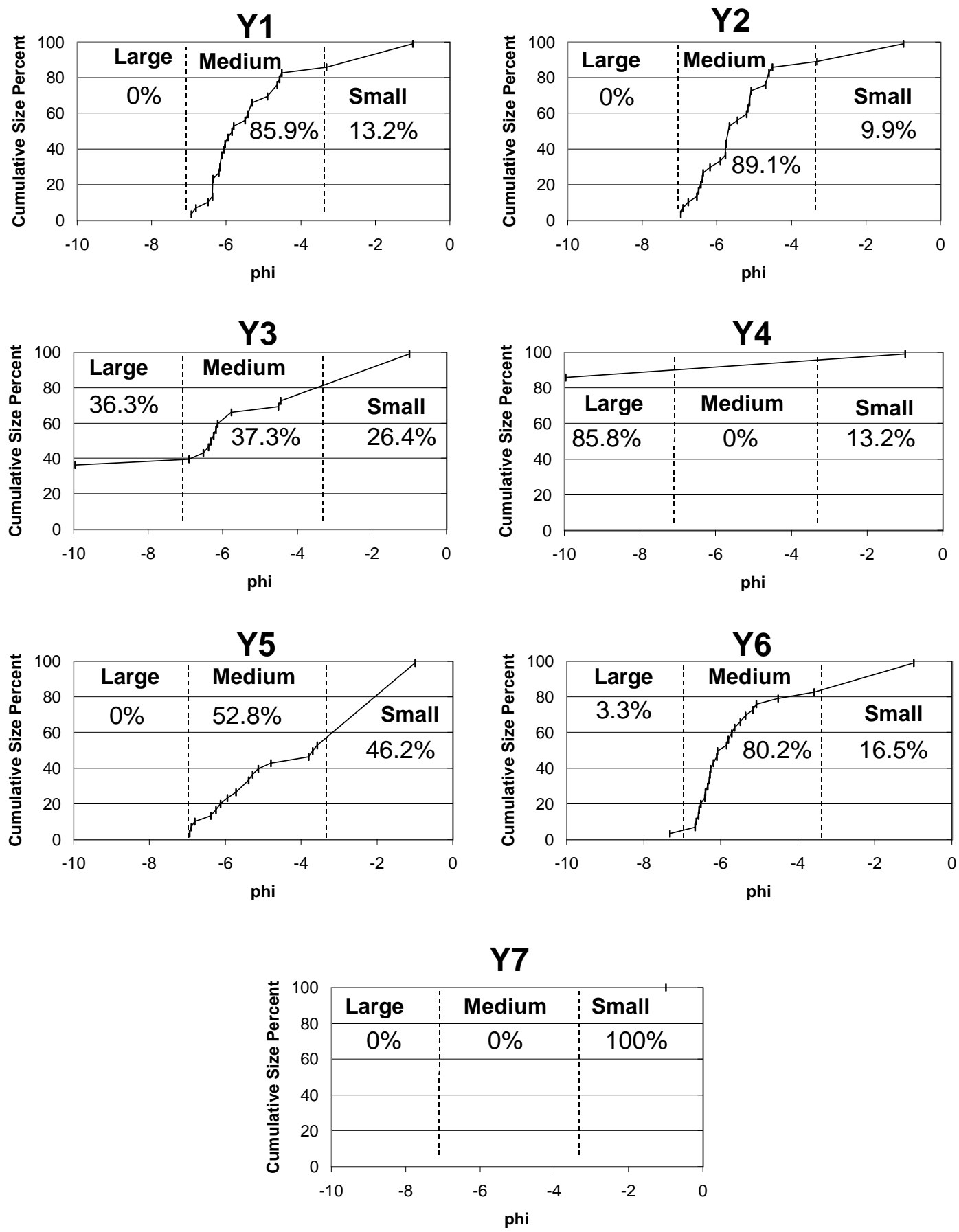

Figure 48. Wollman Pebble Count results for Stream $Y$ at Mine Z. Cumulative frequency plot of cumulative percentage versus sediment particle size (phi units). Data were obtained on August 18, 1999. 

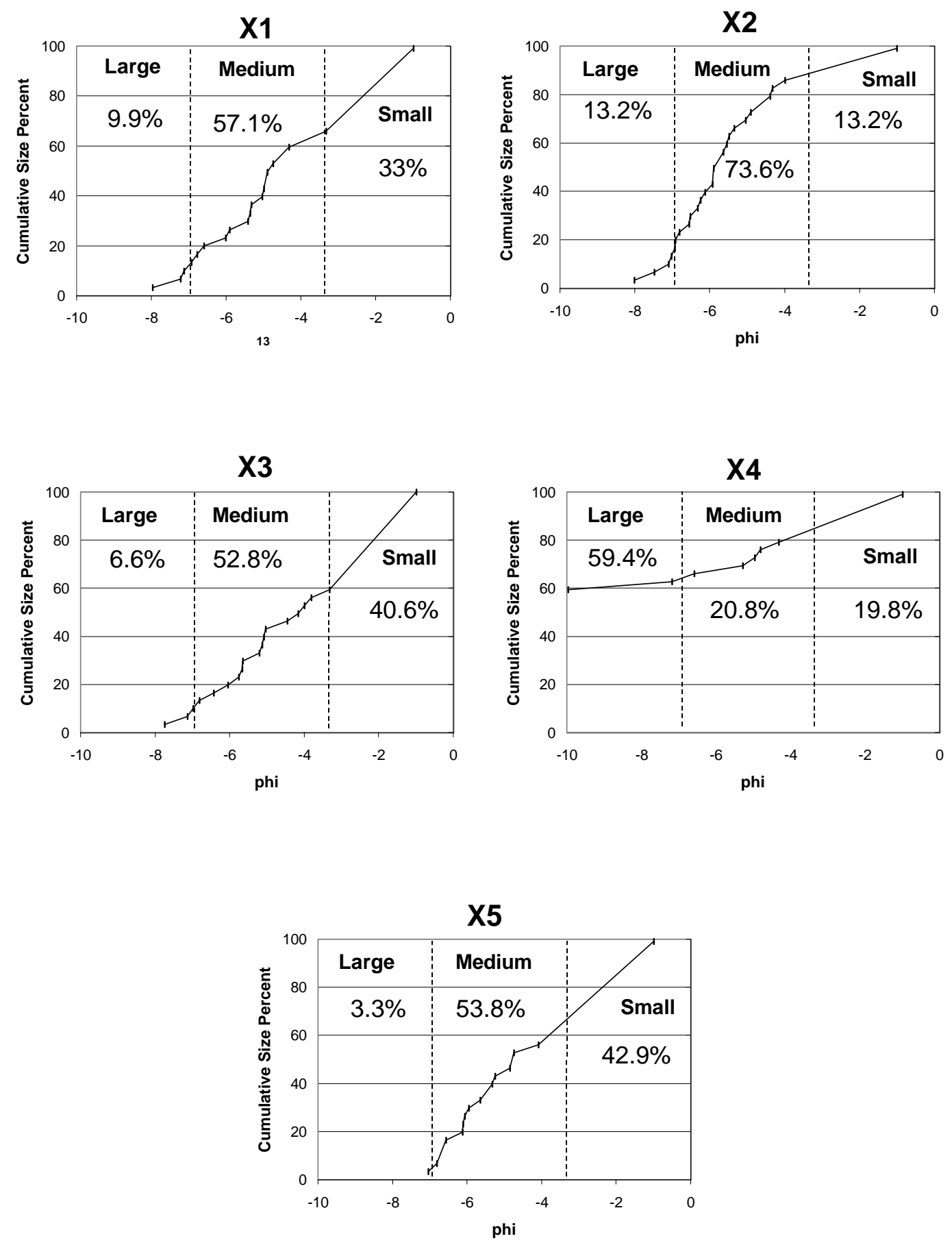

Figure 49. Wollman Pebble Count results for Stream $X$ at Mine Z. Cumulative frequency plot of cumulative percentage versus sediment particle size (phi units). Data were obtained on August 18, 1999. 
increase underflow at the expense of stream channel flow. This conclusion supports the theory that dewatering impacts observed in Streams J, SF, K, and $\mathrm{S} 1$ are all associated with mining subsidence and not other causes, as control Streams $\mathrm{X}$ and $\mathrm{Y}$ have similar geologic settings to Streams J, SF, K, and S1. 


\section{DISCUSSION}

\section{Stream Flow}

\section{Water Balance Equation}

The regional water balance is addressed by the application of the water balance equation to a watershed. The watershed area, delimited by the drainage divides, is the upper surface of the control volume; the sides of the volume extend vertically downward from the divide some indefinite distance assumed to be below the level of significant ground-water movement (Dingman, 1994). Figure 50 shows the various components of the water balance equation. The water balance equation for a time period (modified from Dingman, 1994) is:

$$
P+G_{\text {in }}-\left(Q+E T+U+G_{\text {out }}\right)=0
$$

Rearranging the equation yields:

$$
Q=P+G_{\text {in }}-E T-U-G_{\text {out }}
$$

Assuming that changes in storage will be effectively zero $(\Delta S=0)$ :

$$
Q=P-E T-U
$$

where: $\quad P=$ precipitation,

$$
\begin{aligned}
& G_{\text {in }}=\text { ground water inflow, } \\
& Q=\text { stream outflow or discharge, }
\end{aligned}
$$

$\mathrm{ET}=$ evapotranspiration,

$\mathrm{G}_{\text {out }}=$ ground water outflow, other than underflow

$\mathrm{U}=$ underflow or ground water outflow under the major watershed stream

For equation 15 , long-term average values of $\mathrm{Q}, \mathrm{P}, \mathrm{ET}$, and $\mathrm{U}$ are typically required to ensure a balanced equation. For this study, discharge measurements were taken over a period of a few hours for each plotted graph; this lessens or eliminates the additional effect of ET on measured streamflow. 


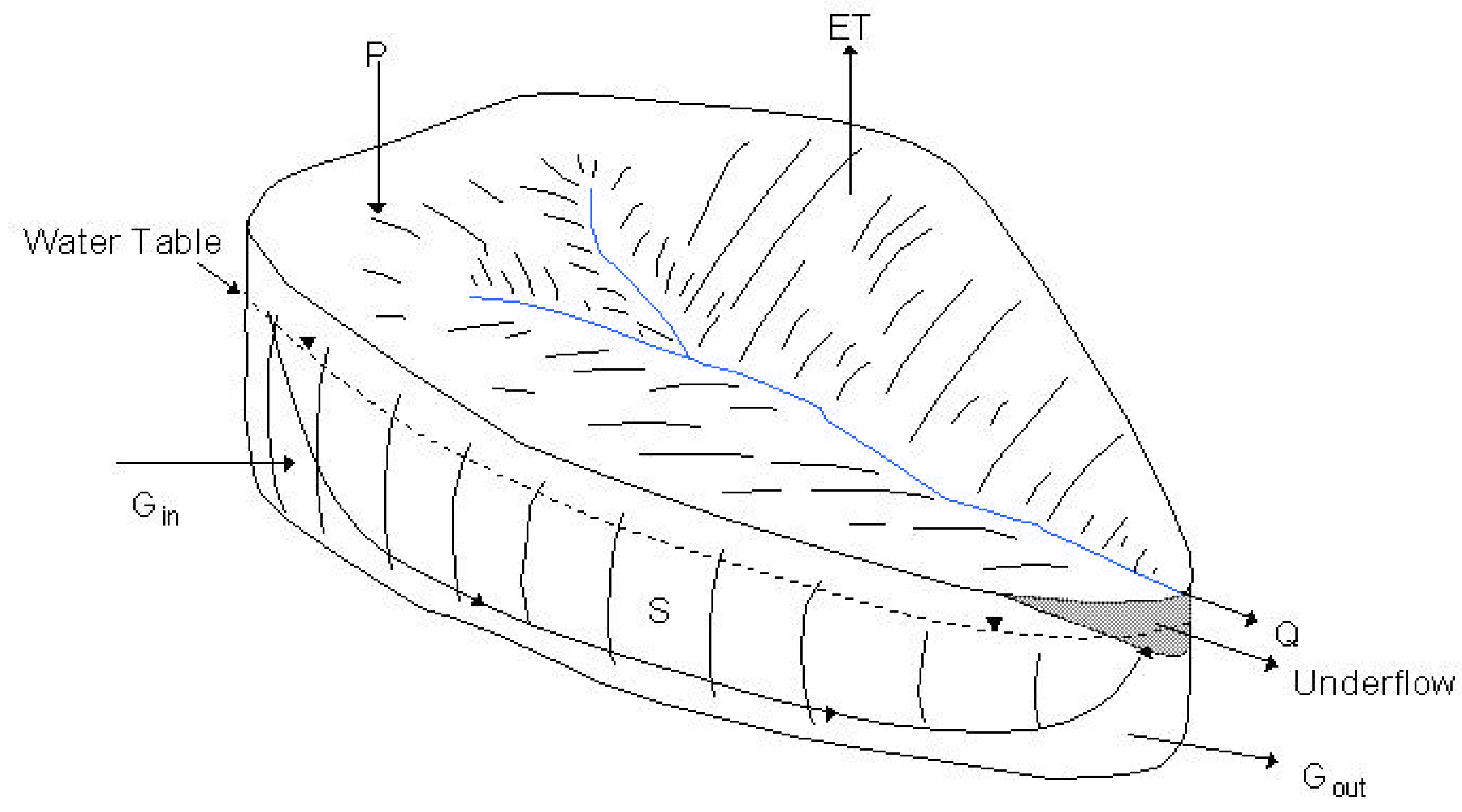

Figure 50. A basic conceptual schematic of a watershed which shows the necessary components of the regional water balance, whereby $\mathrm{P}=$ precipitation, $E T$ = evapotranspiration, $Q=$ stream outflow, $G_{\text {in }}=$ ground-water inflow, $G_{\text {out }}=$ ground-water outflow, except for stream channel underflow which is shallow ground water exiting the watershed under the stream channel (modified from Dinaman. 1994). 
Also, ET is assumed to occur at a constant rate over a short period of time so applying ET rates to discharge data should not have resulted in any change in overall data interpretation for comparing $Q: A_{\text {ratios }}$ among stations.

A variation of the water balance equation, applied specifically to valley discharge, and assuming uniform precipitation and geologic setting, is:

$$
\left(Q_{T}+U_{T}\right) / A_{T}=\left(Q_{S}+U_{S}\right) / A_{S}
$$

where: $\mathrm{Q}_{\mathrm{T}}=$ total cumulative stream discharge from a basin

$\mathrm{U}_{\mathrm{T}}=$ total cumulative amount of underflow beneath basin streambed

$A_{T}=$ total cumulative area of a basin

$\mathrm{Q}_{\mathrm{S}}=$ stream discharge of a sub-basin

$U_{S}=$ underflow beneath the streambed in a sub-basin

$A_{S}=$ area of a sub-basin

Since the variable of underflow cannot be measured directly, a basin that is unimpacted by mining should have a $Q_{T} / A_{T}$ ratio that is proportionally equivalent to one of its unimpacted sub-basins $\left(Q_{S} / A_{S}\right)$. For streams impacted by longwall mining, the $Q_{S} / A_{S}$ ratio will fluctuate relative to the $Q_{T} / A_{T}$ ratio for that basin.

Figure 51 shows a generalized diagram of the ground surface and subsurface for pre-mine, post-mine transitional and post-mine equilibrium basin hydrogeologic setting, as previously hypothesized for Mine Z by Tieman (1986) and Carver (1994). The pre-mine block diagram shows minimal sub-surface fracturing, a high and stable water table, and minimal underflow moving through alluvium beneath the streambed. Pre-mining conditions are steady-state and consistent over time.

The post-mine transitional block diagram (shortly after mine subsidence occurs) shows increased sub-surface fracturing, a lowered water table, and a dry 


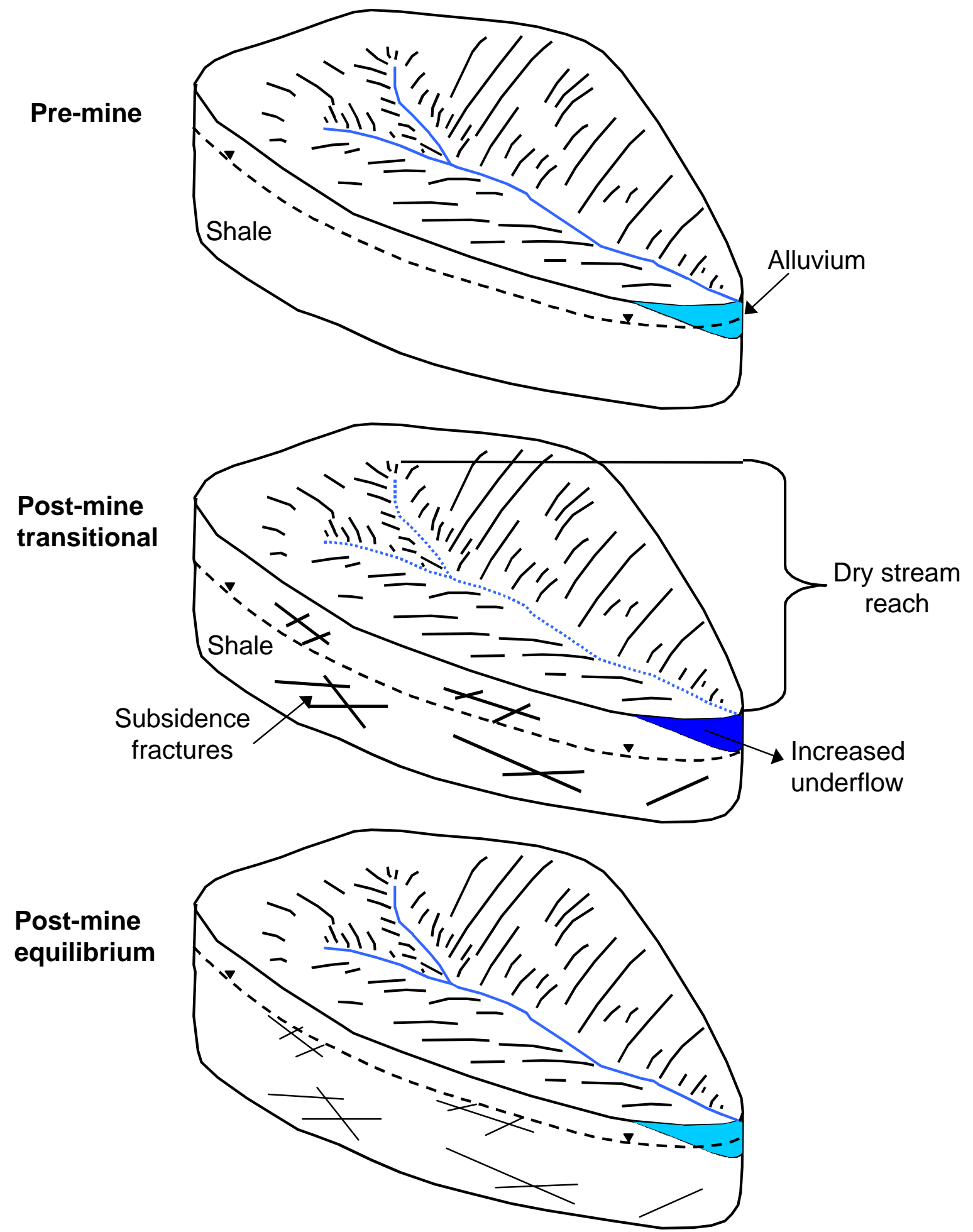

Figure 51. Schematic diagram of pre-mine, post-mine transitional, and post-mine equilibrium basin hydrogeologic setting at Mine $Z$ (Modified from Carver, 1994). 
stream reach, with almost all valley flow traveling as underflow beneath the streambed. Lastly, the post-mine equilibrium block diagram (years after mine subsidence first occurs) shows the same amount of sub-surface fracturing as the post-mine transitional block diagram, but these fractures have sealed with sediment over time. The water table returns to near its higher original pre-mining location and flow returns to the streambed, resulting in minimal underflow. Both the water balance equation (16) and the three mine scenarios presented in Figure 51 will be used to discuss the streamflow results for Mine $Z$ and Mine C.

\section{Pre-mine steady state conditions}

Control Streams $\mathrm{X}$ and $\mathrm{Y}$ are examples of streams in a pre-mine steadystate condition. The control streams show how unimpacted streams may behave. All of the monitoring stations along Stream $Y$ exhibit the same $Q: A_{\text {ratio }}$ as does the last monitoring station, $\mathrm{Y} 7$, which represents the entire cumulative basin $\left(\mathrm{Q}_{\mathrm{T}}\right.$ / $\left.A_{T}\right)$. Since the ratios are the same throughout, basin $Y$ is in a steady-state condition.

Similarly, Stream $X$ is also in a steady-state condition. The $Q: A_{\text {ratio }}$ values at stations $\mathrm{X} 1$ through $\mathrm{X} 4$ are the same as the cumulative basin value at station $X 5$. Also, the net corrected discharge values for both Streams $Y$ and $X$ show no net influx or net loss of water from the system. 


\section{Post-mine transitional conditions}

Streams $\mathrm{K}, \mathrm{SF}$, and $\mathrm{J}$ at Mine $\mathrm{Z}$ and Stream 1 at Mine $\mathrm{C}$ show evidence of impact by longwall mining and are in a transitional state. Table 3 lists stream monitoring stations and their measured corresponding angles of dewatering influence.

Table 3. Angles of dewatering influence for impacted stream stations at Mine $Z$ and Mine $\mathrm{C}$, with respect to nearest downstream panel.

\begin{tabular}{c|c|c|c} 
Station & Angle of Dewatering & Panel & Mine \\
\hline K10 & $15^{\circ}$ & P30 & Z \\
K9 & $4^{\circ}$ & P30 & Z \\
& & & \\
SF4 & $29^{\circ}$ & P40 & $Z$ \\
SF5 & $17^{\circ}$ & P39 & Z \\
SF6 & $<1^{\circ}$ & P39 & Z \\
SF7 & $11^{\circ}$ & P38 & Z \\
SF9 & $11^{\circ}$ & P37 & Z \\
J2 & $22^{\circ}$ & P39 & Z \\
J3 & $20^{\circ}$ & P39 & Z \\
J5 & $10^{\circ}$ & P39 & $Z$ \\
J6 & $6^{\circ}$ & P39 & $Z$ \\
J11 & $8^{\circ}$ & P38 & $Z$ \\
S12 & $<36^{\circ}$ & P1 & C
\end{tabular}

The Q: $A_{\text {ratio }}$ for Stream K consistently decreases from station to consecutive downstream station. These decreases are the result of two undermined panels. The section of one panel underlying part of Stream K was mined out by June of 1992 and the other panel was mined out between May and August of 1993. The $Q: A_{\text {ratio }}$ at station $K 1$ is 36 percent less than the $Q: A_{\text {ratio }}$ at the most upstream station (K8). The current minimum angle of dewatering influence from mined panels is $15^{\circ}$. 
The 6 to 7 years since undermining for Stream $\mathrm{K}$ should have been long enough for the subsidence fractures to heal and to allow normal flow to return to the stream, according to Carver (1994), but it was not. The results of the Wolman pebble count for Stream K suggest that thin alluvium (less than five inches) and a poorly sorted alluvial particle-size distribution can prolong and enhance stream dewatering of a basin long past the previously suggested 1 to 3 years recovery period.

Stream SF progressively loses water at most consecutive downstream stations below SF3, while SF1, SF2, and SF3 have fairly consistent Q: $A_{\text {ratio }}$ values. Since stations SF1, SF2, and SF3 are not undermined, and have consistent $Q: A_{\text {ratio }}$ values, they can be used as the control values for the stream. This suggests that most Stream SF monitoring stations downstream of SF3 are mining impacted, as such stations have Q:Aratio values less than those of SF1 to SF3. Panels P37, P38, P39, and P40 have a negative impact on Stream SF. The mined panel ages range from 2.2 years to 0.2 years, with angles of dewatering influence that range from $<1^{\circ}$ to $29^{\circ}$. Dewatering is much less prevalent In areas where alluvium is thicker than 10 inches within the $29^{\circ}$ angle zone.

Stream J also shows signs of negative impacts in 1999 by panels P38, $\mathrm{P} 39$, and P40 (Figure 34). The calculated value at $\mathrm{J} 1$ is assumed to represent the control Q: $A_{\text {ratio }}$ value for the watershed. All of the downstream stations have $\mathrm{Q}: A_{\text {ratio }}$ values less than the initial $\mathrm{J} 1$ value, suggesting that the entire stream downstream from $\mathrm{J} 1$ is negatively impacted by undermining. No such impacts 
are apparent in the 1992 data of Carver (1994), measured before undermining occurred. The dates for mining of panels P38, P39, and P40 under Stream J range from June 1998 to June 1999, respectively. This indicates that Stream $\mathrm{J}$ is impacted by panels mined out less than 26 months ago. Angles of dewatering influence range from $6^{\circ}$ to $22^{\circ}$ for Stream $\mathrm{J}$. $\mathrm{J} 1$ is located at a vertical angle of $26^{\circ}$ from Panel $\mathrm{P} 39$, which is outside the maximum range of dewatering influence for this watershed. The maximum dewatering angle for Stream $\mathrm{J}$ is therefore between $22^{\circ}$ and $26^{\circ}$. Sediment data (alluvial thickness and Wolman pebble count) suggest that a thin alluvial cover, combined with a poorly sorted sediment, promotes Stream J dewatering.

Stream Segment 1 (Mine C) shows impacts similar to that of Stream K. Both streams have underlying panels mined out longer than 3 years ago, relatively small drainage basins, and bedrock exposed over a large reach of the streambed. Stations $\mathrm{S} 12$ and S1a have very similar high Q: $\mathrm{A}_{\text {ratio }}$ values, suggesting that these represent the normal $Q: A_{\text {ratio }}$ values for the entire watershed. Stream dewatering is a result of longwall panels P1, P2, and P3, which were mined 12 to 13 years ago (Dixon, 1988). The maximum current dewatering angle of influence for Mine $\mathrm{C}$ panels is less than $36^{\circ}$. As with Stream $\mathrm{K}$, Stream Segment 1 experiences stream dewatering along stream sections that have no alluvial cover. Flow returns at the downstream-most station, perhaps from an increase in alluvial thickness or from a lower stream gradient. 


\section{Post-mine equilibrium conditions}

Streams $\mathrm{G}$ and $\mathrm{H}$ at Mine $\mathrm{Z}$ and Stream $\mathrm{S} 2$ at Mine $\mathrm{C}$ are in a state of post-mining equilibrium, and are no longer impacted by mine subsidence. These streams were formerly mining impacted (Carver, 1994, Streams G and H; Dixon, 1988, Stream S2). Mining under these selected watersheds occurred several years ago, which apparently has been enough time for shallow subsidence fractures in bedrock to heal. In some cases, subsidence fracturing has increased or improved the quantity of ground water and, hence, streamflow in a valley system by opening more pathways for ground water recharge and flow. Carver (1994) reported about a 33\% reduction in baseflow recession constants for subsided and recovered Mine Z streams compared to nearby unsubsided streams, indicating that baseflow improves (is higher) in the post-mine equilibrium phase.

Tieman (1986) reported that sub-basin G5 showed signs of dewatering, with 28 percent of its watershed undermined by panels less than 2 years old. Re-examination of the same watershed 13 to 14 years later suggests that the fractures have healed and dewatering at G5 is no longer occurring. There are no major fluctuations in the adjusted discharge: area ratio plot (Figure 20). A slight increase from G5 to G3 suggests that old subsidence fractures may have opened preferential pathways, increasing the amount of ground water discharge entering the stream channel. The thickness of the streambed alluvium varies along Stream G. Station G1 is totally lacking alluvium, but this does not negatively affect the $Q: A_{\text {ratio }}$ there, suggesting a full recovery. 
Mining occurred 6.4 years before Carver's study at Stream $\mathrm{H}$. The mine subsidence that affected Stream $\mathrm{H}$ actually increased stream discharge (Carver, 1994). Data collected in 1999 for Stream H suggest no negative impacts from mine subsidence. Alluvium thickness (approximately 17 inches) is quite similar at the four stations along Stream $\mathrm{H}$.

Dixon's (1988) results for Stream Segment 2 at Mine C suggest that panel P3 had a negative impact on stations S2-4 and S2-5. Adjusted discharge: area ratio (Figure 40) shows no significant decrease in the $Q: A_{\text {ratio, }}$ suggesting that ground subsidence fractures no longer have a negative impact on this watershed, about 11 years after panel P3 was mined. 


\section{CONCLUSIONS}

1. Streams located on solid ground that has not been undermined and is not within the angle of dewatering influence of a nearby underground mine show no signs of dewatering.

2. Stream dewatering in the vicinity of Mines $Z$ and $C$ is the result of the close location of mined out longwall panels, relative to the streams. Specifically, subsidence resulting from such longwall mining often reduces or eliminates normal stream discharge. Many factors determine the duration and severity of dewatering. Streams experienced dewatering from panels mined within the last month, which was expected, and from panels mined as long ago as 13 years, which was unexpected.

3. Angles of dewatering influence ranged to a maximum of $29^{\circ}$ and $<36^{\circ}$ at Mines $Z$ and $C$ streams, respectively. These angles suggest that streams located at least $30^{\circ}$ to $36^{\circ}$ vertically from upstream longwall panel edges should not be affected by mine subsidence. Land within vertical angles of less than $30^{\circ}$ to $36^{\circ}$ from longwall panels represent regional subsidence strain areas, with apparent enhanced vertical permeability and streamflow loss due to subsidence fractures in shallow bedrock.

4. Lost flow at impacted streams travels as laterally moving underflow water in shallow aquifers at Mines $Z$ and $C$. It is unlikely that the lost stream water travels down to the underground mine because of the thick rock overburden containing confining layers above Mine Z (>800 feet) and above Mine $Z$ (>600 feet). Mine Z personnel report little mine recharge of ground water. 
5. Stream segments between two adjacent longwall panels often experienced dewatering effects from overlapping tensional strain areas. Segments of dewatered streams located near an edge of a longwall panel may experience a temporary increase in discharge. This increase may result from underflow ground water being forced back into the streambed as it moves through a transition zone between tensional and compressional strain areas.

6. Impacted (dewatered) streams with a downstream increase in specific conductivity and decrease in temperature show evidence of increased ground water discharge additions to streamflow, probably from mining impacted underflow water in shallow aquifers, under certain circumstances.

7. A lack of thick alluvium (less than 10 inches) in the streambed and a lack of well sorted medium sized streambed sediment (small pebble to small cobble size) may prolong stream dewatering of subsidence impacted streams for at least 13 years. Streams with thick sediment, having 60 percent or greater medium sized (small pebbles to small cobbles) particles with at least some fine sediment (mostly sand and finer particles) experienced less dewatering impacts from mine subsidence. Apparently fine sediment is useful for sealing subsidence cracks in shallow bedrock under stream channels, but only if there is a good base of medium sized sediment to serve as an anchor.

8. Stream dredging is not an effective measure for negating the effects of stream dewatering but does return free drainage (less ponding) following longwall mining subsidence. 


\section{RECOMMENDATIONS}

\section{For Future Research Studies}

This short-term study analyzed how streamflow discharge was affected by undermining. Limited time, funding, and field assistance hindered the scope of this project. A more thorough identification of streamloss from undermining and subsidence impacts would be better recognized from a long-term study over many years, with consistent monitoring stations and techniques. The study area should include only a limited amount of undermined streams (5 or 6$)$ to be studied along with one non-undermined control stream. The reduction in the amount of streams studied would decrease the amount of time traveling to various study sites and give the investigator the ability to monitor all streams on the same day. Ideally, the control stream should remain non-undermined for at least one year. If possible, all basins should be monitored regularly for discharge, temperature, conductivity, alluvium thickness, and sediment size distribution for at least one year. Installation of permanent stream gauging stations for all streams involved is recommended. Data interpretation can be simplified by examining stream discharge for downstream discharge changes. Dividing the discharge by the drainage basin acreage (as done in this study) can, at times, be confusing and may increase the overall measurement error. Data from the non-undermined stream basin would then be analyzed and compared to data from undermined basins for possible extraneous influences, such as diurnal and seasonal evapotranspiration variations. 


\section{For Environmental Mitigation by Mining Companies}

Some data from this study suggest that stream dewatering impacts from underground mining within land subsidence zones may be partially negated. Impacted streams seemed to loose less water to the subsurface along areas that had a relatively thick ( $>10$ inches) alluvial cover and a majority of medium sized sediments in the stream channel. Combining and introducing these two factors into areas where major mine related stream dewatering impacts occur should lessen the overall amount of stream water entering the subsurface. Applied course (granule to cobble) sediment could serve as a relatively stable stream base, with applied fine (clay to sand) sediment to seal sediment subsidence cracks.

Stream dredging has been an effective technique used to relieve areas of ponded water resulting from mine subsidence. A combination of stream dredging and sediment introduction to mine subsidence impacted areas may be the most practically effective method for combating both stream flooding and stream loss.

A third, and less probable, method to control stream loss from mining impacts is to only allow longwall mining outside of the maximum angle of dewatering influence of a watershed. An imaginary "buffer zone" would be created on both sides of the stream. This technique would most likely negate all water losses from mining, but would result in less overall coal production and would, therefore, not likely be financially prudent. 


\section{REFERENCES}

Bowers, J.L., 1979. The Effects of Coal Mining on the Surface and Ground Waters of the Scotts Run Drainage Basin: unpublished M.S. thesis, Department of Geology and Geography, West Virginia University, Morgantown, West Virginia, 90 p.

Carver, L.S., 1994. Hydrogeologic Effects of Subsidence at a Longwall Mine in the Pittsburgh Coal Seam: unpublished M.S. thesis, Department of Geology and Geography, West Virginia University, Morgantown, West Virginia, 225 p.

Carver, L.S., and Rauch, H.W., 1994. Hydrogeologic Effects of Subsidence at a Longwall Mine in the Pittsburgh Coal Seam; in Proceedings of the Thirteenth Annual Conference on Ground Control in Mining, College of Mineral and Energy Resources, West Virginia University, Morgantown, West Virginia, 249-263 p.

Cifelli, R.C., 1986. Dewatering Effects Due to Underground Coal Mining in Barbour and Upshur Counties of North-Central West Virginia: unpublished M.S. thesis, Department of Geology and Geography, West Virginia University, Morgantown, West Virginia, $245 \mathrm{p}$.

Cifelli, R.C., and Rauch, H.W., 1986. Dewatering Effects from Selected Underground Coal Mines in North-Central West Virginia; in Proceedings of the Second Workshop on Surface Subsidence Due to Underground Mining, COMER, West Virginia University, Morgantown, West Virginia, 249-263 p.

Coe, C.J., and Stowe, S.M., 1984. Evaluating the Impact of Longwall Coal Mining on the Hydrologic Balance; in Proceedings of the Conference on the Impact of Mining on Ground Water, National Water Well Association, Dublin, Ohio, 348-359 p.

Dingman, S.L., 1994. Physical Hydrology. Macmillan Publishing Company, New York, New York, 536-552 p.

Dixon, D.Y., 1988. A Study of the Dewatering Effects at Three Longwall Mines in the Northern Appalachian Coal Field, Unpublished Thesis, Morgantown, West Virginia $250 \mathrm{p}$.

Dixon, D.Y., and Rauch, H.W., 1988. Study of Quantitative Ground Water Impacts from Longwall Mine Subsidence; in Proceedings of the Seventh International Conference on Ground Control in Mining, COMER, West Virginia University, Morgantown, West Virginia, 321-335 p.

Dixon, D.Y., and Rauch, H.W., 1990. The Impact of Three Longwall Coal Mines on Streamflow in the Appalachian Coal Field; in Proceedings of the Ninth International Conference on Ground Control in Mining, COMER, West Virginia University, Morgantown, West Virginia 169-182 p.

Driscoll, F.G., 1986. Groundwater and Wells, Second Edition. Johnson Division Publishing, St. Paul, Minnesota 541-547 p. 
Evaldi, R.D., and McClain, D.L., 1989. Streamflow, Specific-Conductance, and Temperature Data for Bayou and Little Bayou Creeks near Paducah, Kentucky, August 15 and 16, 1989: U.S. Geological Survey Open-File Report 89-582. Denver, Colorado $19 \mathrm{p}$.

Fetter, C.W., 1994. Applied Hydrogeology, third edition. Prentice Hall, Inc. Englewood Cliffs, New Jersey, 691 p.

Folk, R.L., 1965. Petrology of Sedimentary Rocks. Hemphill's Publishing, Austin, Texas $159 \mathrm{p}$.

Ground Water Associates, Inc., 1984, Effects of Land Subsidence on the Hydrologic Balance in the Vicinity of the Meigs No. 2 Mine, Meigs and Vinton Counties, Ohio: Report to Department of Natural Resources, Division of Reclamation, Columbus, Ohio, $65 \mathrm{p}$.

Hennen, R.V., and Reger, D.B., 1913. Marion, Monongalia, and Taylor County Reports: West Virginia Geological and Economic Survey County Report, Morgantown, West Virginia, $844 \mathrm{p}$.

Linsley, R.K., Kohler, M.A., and Paulhus, J.L., 1975. Hydrology for Engineers: Second Edition. McGraw-Hill Publishing, New York, NY, 446 p.

Kresic, N, 1997. Quantitative Solutions in Hydrogeology and Groundwater Modeling. Lewis Publishers, Boca Raton, Florida, 461 p.

Marsh-McBirney, Inc., 1984, Field Operations Manual, Frederick, Maryland, 4 p.

Mine Z Company, 1999, Personal Communication, West Virginia.

Parizek, R. R., and Ramani, R, V., 1995. Longwall Coal Mines Pre-Monitoring and Water Supply Replacement Alternatives; Workshop on Longwall Mining and Rural Water Supplies, Holiday Inn, Pittsburgh South Hills, Pennsylvania, 94 p.

Peng, S.S., 1992. Surface Subsidence Engineering. Society for Mining, Metallurgy, and Exploration, Inc., $161 \mathrm{p}$.

Peng, S.S., and Chiang, H.S., 1984. Longwall Mining. John Wiley and Sons, New York, New York, $450 \mathrm{p}$.

Pluhowski, E.J., 1970. Urbanization and Its Effect on the Temperature of Streams on Long Island, New York: U.S. Geological Survey Professional Paper 627-D,110 p.

Rauch, H.W., 1989. A Summary of Ground Water Impacts from Underground Longwall Mine Subsidence in the North Central Appalachians; in Proceedings of Special Institute on Coal Mine Subsidence, Eastern Mineral Law Foundation, Westin William Penn Hotel, Pittsburgh, Pennsylvania, 201-231 p. 
Reed, C., 1998. Hydrogeologic Analysis of Streamflow for Spruce Laurel Fork in Relation to Underground Mines in Boone County, West Virginia; unpublished MS option II project. Department of Geology and Geography, West Virginia University, Morgantown, West Virginia, $46 \mathrm{p}$.

Tieman, G.E., 1986. Study of Dewatering Effects of Two Underground Longwall Mine Sites in the Pittsburgh Coal Seam of the Northern Appalachian Coal Field; unpublished M.S. thesis, Department of Geology and Geography, West Virginia University, Morgantown, West Virginia, $147 \mathrm{p}$.

Tieman, G.E., and Rauch, H.W., 1987. Study of Dewatering Effects at an Underground Longwall Mine Site in the Pittsburgh Coal Seam of the Northern Appalachian Coal Field; in Proceedings of U.S. Bureau of Mines Technology Transfer Seminar, Information Circular 9137, U.S. Bureau of Mines, Pittsburgh, Pennsylvania, 72-89 $\mathrm{p}$.

Tieman, G.E., Rauch, H.W., and Carver, L.S., 1992. Study of Dewatering Effects at a Longwall Mine in Northern West Virginia; in Proceedings of the Third Workshop on Surface Subsidence Due to Underground Mining, COMER, West Virginia University, Morgantown, West Virginia, 214-221 p.

Stevens, H.H., Ficke, J.F., and Smoot, G.F., 1975. Techniques of Water-Resource Investigations of the United States Geological Survey; Water TemperatureInfluential Factors, Field Measurement, and Data Presentation. U.S. Government Printing Office, Washington, DC, 65 p.

U.S. Department of the Interior, Bureau of Reclamation, 1953. Water Measurement Manual; A manual pertaining to measurement of water for irrigation projects. Denver, Colorado, 7-27 p.

Wolman, M.G., 1995. The Natural Channel of Brandywine Creek Pennsylvania, U.S. Geological Survey Professional Paper 271. Washington: U.S. Government Printing Office. 


\section{APPENDICES}

\section{Appendix A: Stream Discharge Data}

May 3, 1999
$\begin{array}{llll}\text { H3 } & 15: 28 & 199.81 & 2.08 \\ \text { H2 } & 15: 47 & 272.29 & 0.61\end{array}$
$\begin{array}{llll}\text { H2 } & 15: 47 & 272.29 & 0.61\end{array}$
H1 $16: 04 \quad 342.99 \quad 0.61$
H4 $\quad 16: 18 \quad 384.14 \quad 0.58$

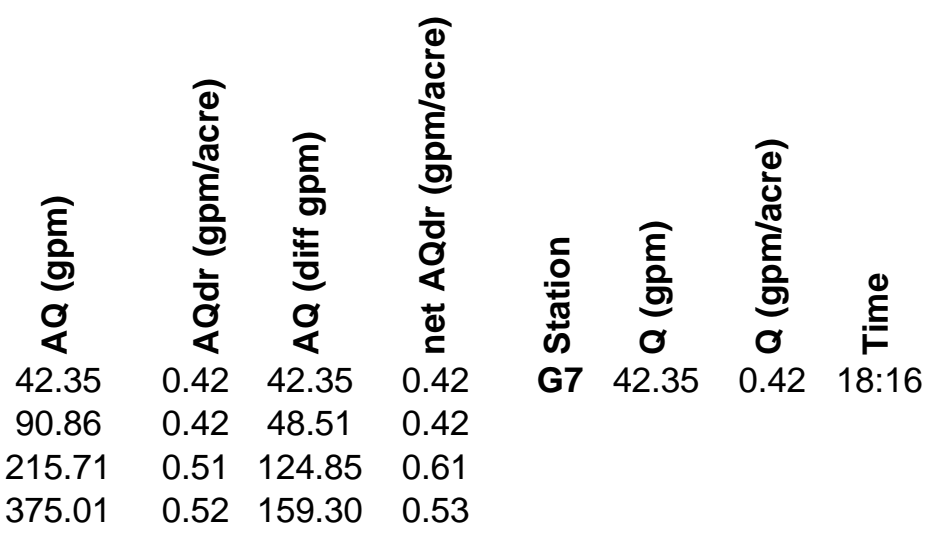

$\begin{array}{ccccc}5.25 & 158.80 & 0.47 & 158.80 & 0.47 \\ & 233.63 & 0.43 & 74.83 & 0.37 \\ 313.10 & 0.56 & 79.47 & 4.18 \\ & 369.04 & 0.55 & 55.94 & 0.51\end{array}$

H3 $158.801 .65 \quad 16: 31$

$\begin{array}{llll}\text { K8 } & 17.13 & 0.44 & 15: 11\end{array}$

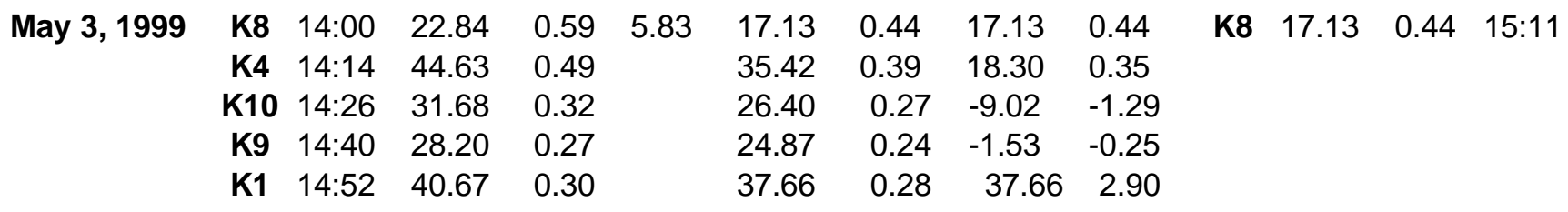

Q (gpm) = discharge in gallons per minute

Qdr (gpm/acre) = discharge ratio; discharge divided by basin acreage a $(\mathrm{gpm} / \mathrm{acre})=$ baseflow recession constant $\mathbf{A Q}(\mathbf{g p m})=$ time adjusted discharge in gallons per minute

AQdr (gpm/acre) $=$ time adjusted discharge ratio; time corrected discharge divided by basin area

$\mathbf{A Q}$ diff $(\mathbf{g p m})=$ time adjusted discharge value difference between given station and next upstream station

net AQdr (gpm/acre) $=$ time adjusted discharge value difference between two consecutive monitoring stations divided by the difference in sub-basin area between the same two stations(given station and next upstream station)

na $=$ not available (not measured) data 
Appendix A: Stream Discharge Data

Date April 25, 1999

April 29, 1999

May 21, 1999

\section{Appendix A :}

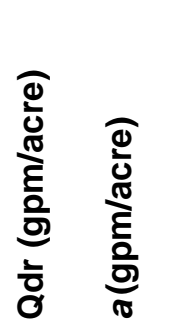

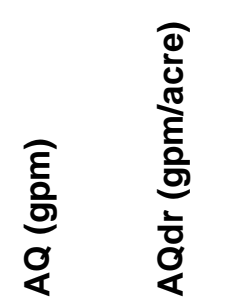

na na

na na

na na

J3 na na na

$\begin{array}{cccc}\text { J4 } & 9: 57 & 528.21 & 3.29 \\ \text { J5 } & 10: 00 & 482.30 & 2.95\end{array}$

$\begin{array}{llll}\text { J6 } & 10: 07 & 504.94 & 3.04\end{array}$

$\begin{array}{llll}\text { J7 } & 10: 10 & 418.08 & 2.46\end{array}$

$\begin{array}{llll}\text { J8 } & 10: 17 & 552.10 & 3.17\end{array}$

$\begin{array}{llll}\text { J9 } & 10: 34 & 630.00 & 3.43\end{array}$

$\begin{array}{llll}\text { J10 } & 10: 43 \quad 770.00 & 3.26\end{array}$

$\begin{array}{ll}482.70 & 2.91\end{array}$

$\begin{array}{ll}399.67 & 2.35\end{array}$

527.793 .03

$587.94 \quad 3.06$

$760.96 \quad 3.05$ $\begin{array}{ll}504.94 & 3.15 \\ 461.06 & 2.82\end{array}$

$\begin{array}{lrrrrrrrr}\text { J1 } & 9: 35 & 186.00 & 1.23 & 0.50 & 172.62 & 1.15 & 172.62 & 1.15 \\ \text { J2 } & 9: 53 & 151.93 & 0.98 & & 141.01 & 0.91 & -31.62 & -6.56 \\ \text { J3 } & 9: 57 & 151.93 & 0.96 & & 141.20 & 0.89 & 0.20 & 0.07 \\ \text { J4 } & 10: 00 & 151.93 & 0.95 & & 141.35 & 0.88 & 0.15 & 0.08 \\ \text { J5 } & 10: 05 & 151.93 & 0.93 & & 141.60 & 0.87 & 0.24 & 0.08 \\ \text { J6 } & 10: 09 & 163.35 & 0.98 & & 152.45 & 0.92 & 10.85 & 3.85 \\ \text { J7 } & 10: 12 & 141.01 & 0.83 & & 131.73 & 0.78 & -20.72 & -5.69 \\ \text { J8 } & 10: 15 & 151.93 & 0.87 & & 142.09 & 0.82 & 10.36 & 2.32 \\ \text { J9 } & 10: 23 & 202.00 & 1.05 & & 177.29 & 0.92 & 35.20 & 1.98 \\ \text { J10 } & 10: 35 & 243.00 & 0.98 & & 217.46 & 0.87 & 236.18 & 4.14 \\ \text { J11 } & 11: 25 & 184.00 & 0.71 & & 160.28 & 0.62 & -57.18 & -5.87 \\ \text { J12 } & 11: 48 & 141.00 & 0.50 & & 123.03 & 0.44 & -37.25 & -1.62 \\ \text { J14 } & 12: 27 & 124.00 & 0.42 & & 195.72 & 0.67 & 72.70 & 6.27 \\ \text { J15 } & 12: 46 & 148.00 & 0.44 & & 223.64 & 0.67 & 27.92 & 0.66\end{array}$

$\widehat{\varepsilon}$
응
$\frac{0}{0}$
$\frac{0}{4}$

na

na

na

61.94

$-43.88-14.94$

$21.64 \quad 7.67$

$-83.04-22.80$

128.1228 .69

261.9414 .67

$434.96 \quad 5.78$
Values used to calculate the baseflow recession constant

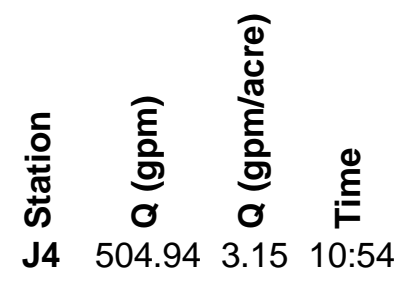

$\begin{array}{lcccccccc}\text { J1 } & & 130.00 & 0.86 & 1.33 & 110.04 & 0.73 & 110.04 & 0.73 \\ \text { J2 } & 10: 12 & 120.43 & 0.77 & & 101.94 & 0.66 & -8.10 & -1.62 \\ \text { J3 } & 10: 15 & 93.37 & 0.59 & & 79.26 & 0.50 & -22.68 & -8.04 \\ \text { J4 } & 10: 20 & 101.94 & 0.64 & & 86.93 & 0.54 & 7.67 & 3.84 \\ \text { J5 } & 10: 25 & 93.37 & 0.57 & & 79.99 & 0.49 & -6.94 & -2.36 \\ \text { J6 } & 10: 30 & 93.37 & 0.56 & & 80.36 & 0.48 & 0.37 & 0.13 \\ \text { J7 } & 10: 34 & 85.26 & 0.50 & & 73.65 & 0.43 & -6.71 & -1.84 \\ \text { J8 } & 10: 39 & 85.26 & 0.49 & & 73.99 & 0.42 & 0.34 & 0.08 \\ \text { J9 } & 10: 48 & 151.72 & 0.54 & & 72.77 & 0.38 & -1.22 & -0.07 \\ \text { J10 } & 11: 11 & 200.35 & 0.60 & & 119.11 & 0.48 & 46.34 & 0.81 \\ \text { J11 } & 11: 37 & 226.46 & 0.53 & & 123.20 & 0.48 & 4.09 & 0.42 \\ \text { J12 } & 12: 10 & 214.48 & 0.48 & & 118.33 & 0.42 & -4.87 & -0.21 \\ \text { J14 } & 12: 43 & 205.07 & 0.34 & & 100.68 & 0.34 & -17.65 & -1.52 \\ \text { J15 } & 12: 55 & 291.49 & 0.45 & & 187.98 & 0.56 & 87.30 & 2.08\end{array}$

J2 $\quad 101.94 \quad 0.66 \quad 13: 12$ 


\section{Appendix A: Stream Discharge Data}

June 16, 1999

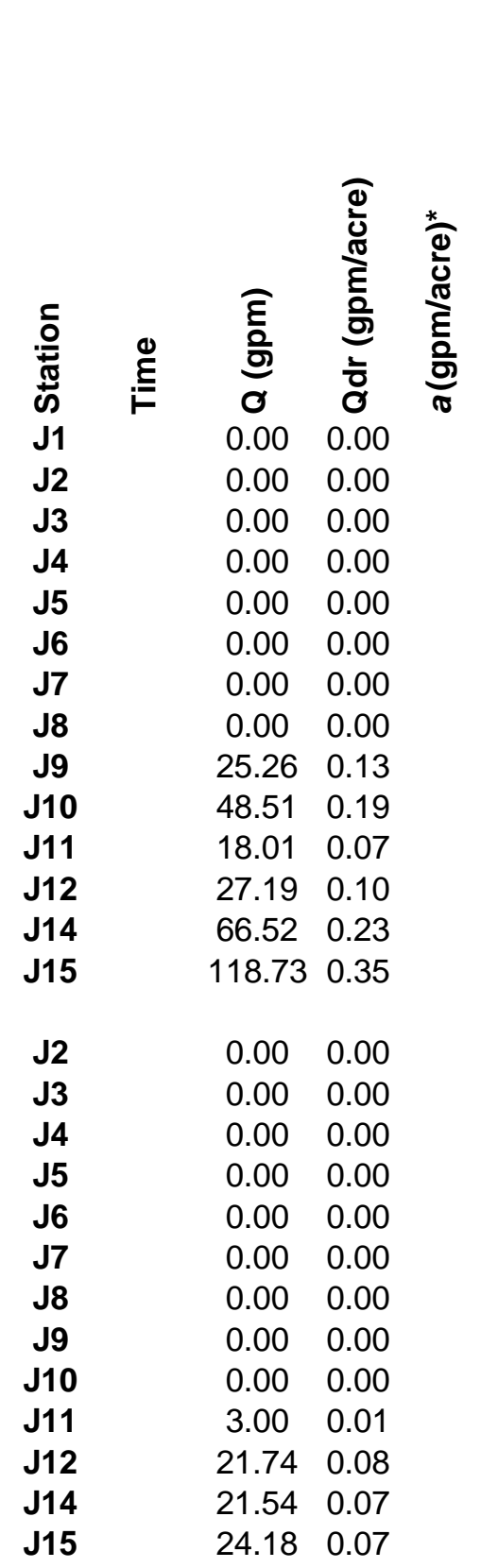

$\begin{array}{rcccccc}\text { August 7, } 1999 & \text { J2 } & 0.00 & 0.00 & 0.00 & 0.00 & 0.00 \\ & \text { J3 } & 0.00 & 0.00 & 0.00 & 0.00 & 0.00 \\ \text { J4 } & 0.00 & 0.00 & 0.00 & 0.00 & 0.00 \\ \text { J5 } & 0.00 & 0.00 & 0.00 & 0.00 & 0.00 \\ \text { J6 } & 0.00 & 0.00 & 0.00 & 0.00 & 0.00 \\ \text { J7 } & 0.00 & 0.00 & 0.00 & 0.00 & 0.00 \\ \text { J8 } & 0.00 & 0.00 & 0.00 & 0.00 & 0.00 \\ \text { J9 } & 0.00 & 0.00 & 0.00 & 0.00 & 0.00 \\ \text { J10 } & 0.00 & 0.00 & 0.00 & 0.00 & 0.00 \\ \text { J11 } & 3.00 & 0.01 & 0.01 & 3.00 & 0.30 \\ \text { J12 } & 21.74 & 0.08 & 0.08 & 18.74 & 0.81 \\ \text { J14 } & 21.54 & 0.07 & 0.07 & -0.20 & -0.02 \\ \text { J15 } & 24.18 & 0.07 & 0.07 & 2.64 & 0.06\end{array}$


Appendix A: Stream Discharge Data

Date

July 12, 1999

$12: 23 \quad 127.60$

SF2 $12: 40-123.00 \quad 0.03$

SF3 $13: 00 \quad 203.32 \quad 0.04$

$\begin{array}{llllll}\text { SF5 } & 14: 28 & 81.87 & 0.01 & -16.65 & -0.83\end{array}$

$\begin{array}{llllll}\text { SF6 } & 14: 52 & 87.11 & 0.01 & 5.24 & 0.48\end{array}$

$\begin{array}{llllll}\text { SF7 } & 15: 44 & 59.04 & 0.00 & -28.07 & -1.17\end{array}$

$\begin{array}{llllll}\text { SF8 } & 15: 58 & 64.25 & 0.00 & 5.22 & 0.10\end{array}$

SF9 $16: 25 \quad 40.75 \quad-0.01 \quad-23.51 \quad-0.25$

$\begin{array}{llllll}\text { SF10 } & 16: 40 & 5.00 & -0.01 & -35.75 & -3.25\end{array}$

$\begin{array}{llllll}\text { SF11 } & 17: 07 & 0.00 & -0.02 & -5.00 & -0.08\end{array}$

$\begin{array}{lllllll}\text { July 21, } 1999 & \text { SF } 1 & 12: 00 & 64.75 & 0.02 & 64.75 & 0.02\end{array}$

SF2 $12.22 \quad 69.99-0.02 \quad 5.24$

$\begin{array}{llllll}\text { SF3 } & 13: 00 & 75.88 & 0.02 & 5.89 & 0.74\end{array}$

$\begin{array}{llllll}\text { SF4 } & 13: 30 & -10.01 & 0.00 & -85.89 & -2.32\end{array}$

$\begin{array}{llllll}\text { SF5 } & 13: 45 & -7.32 & 0.00 & 2.69 & 0.13\end{array}$

$\begin{array}{lllllll}\text { July 26, } 1999 & \text { SF1 } & 10: 45 & 124.25 & 0.03 & 124.25 & 0.03\end{array}$

$\begin{array}{llllll}\text { SF2 } & 10: 59 & 122.71 & 0.03 & -1.54 & -0.51\end{array}$

$\begin{array}{llllll}\text { SF3 } & 11: 30 & 133.46 & 0.04 & 10.75 & 1.34\end{array}$

SF4 $11: 52 \quad 3.65 \quad 0.00$

$\begin{array}{llllll}\text { SF5 } & 12: 09 & -19.81 & -0.01 & -23.46 & -1.17\end{array}$

$\begin{array}{llllll}\text { SF6 } & 12: 20 & 5.84 & 0.00 & 25.66 & 2.33\end{array}$

$\begin{array}{llllll}\text { SF7 } & 12: 37 & -28.72 & -0.01 & -34.57 & -1.44\end{array}$

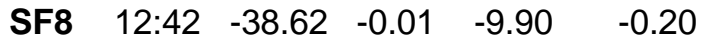

$\begin{array}{llllll}\text { SF9 } & 13: 11 & -38.62 & -0.01 & 0.00 & 0.00\end{array}$

$\begin{array}{llllll}\text { SF10 } & 13: 20 & -38.62 & -0.01 & 0.00 & 0.00\end{array}$

$\begin{array}{llllll}\text { SF11 } & 13: 34 & -38.62 & -0.01 & 0.00 & 0.00\end{array}$

$\begin{array}{llllll}\text { SF12 } & 13: 46 & -177.45 & -0.04 & -138.83 & -13.88\end{array}$

$\begin{array}{llllll}\text { SF13 } & 14: 19 & -125.60 & -0.03 & 51.85 & 0.58\end{array}$
Values used to calculate the baseflow recession constant

के

*baseflow recession constants were calculated but not used for 7/12/99, $7 / 21 / 99$, and $7 / 26 / 99$.

The recession value was too small and did not affect the outcome of the discharge measurements.

**negative $Q$ values resulted at some stations because subtracted tributary flow was greater than the actual flow in the main stream channel. 


\section{Appendix A: Stream Discharge Data}

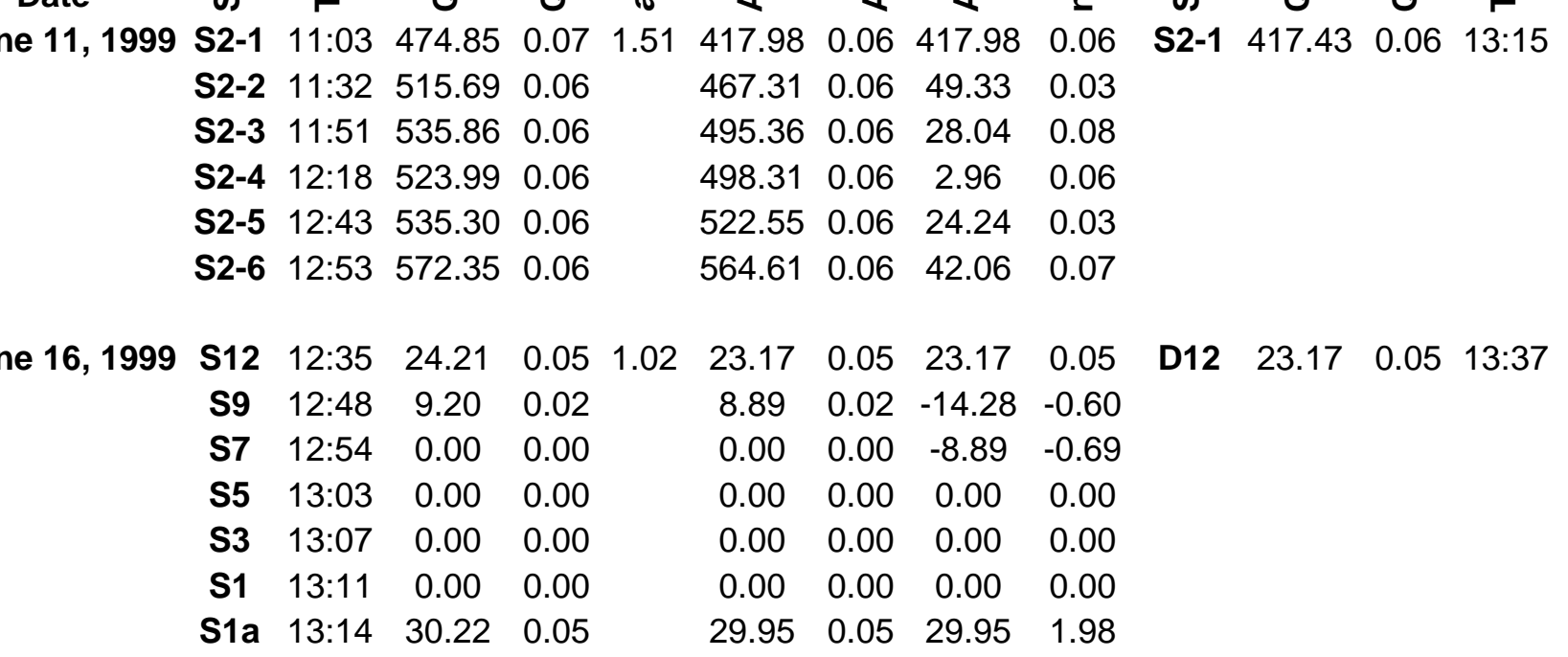




\section{Appendix A: Stream Discharge Data}

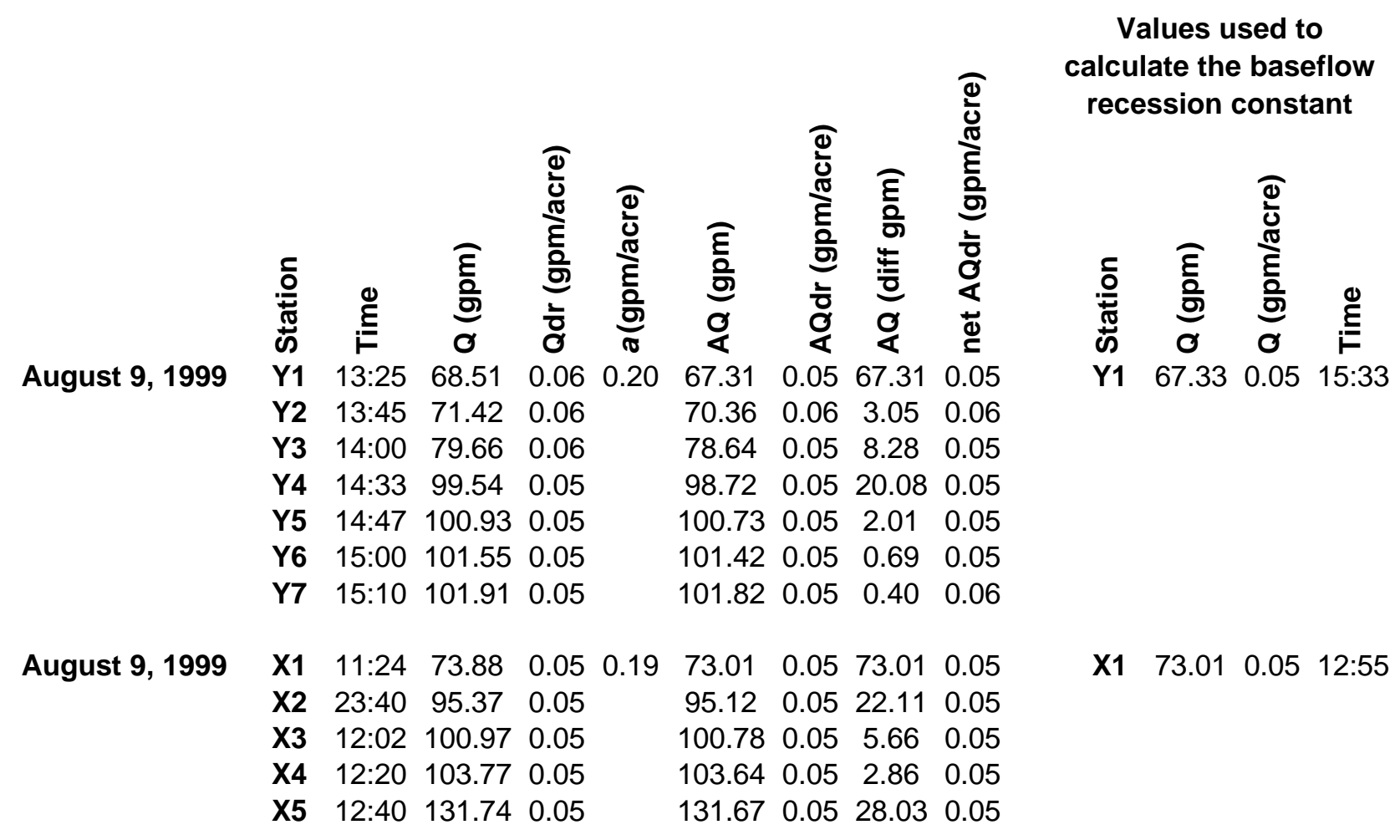




\section{Appendix B: Temperature and Specific Conductivity Data}

\begin{tabular}{|c|c|c|c|c|}
\hline Date & $\frac{5}{\frac{5}{\pi}}$ & U & $\stackrel{\varrho}{\varepsilon}$ & \\
\hline \multirow[t]{5}{*}{ 05/03/1999 } & G7 & 200 & 16 & \\
\hline & G5 & 180 & 20 & \multirow{4}{*}{$\begin{aligned} \mathrm{SC}= & \text { Specific Conductivity } \\
& \text { at } 25 \text { degrees } \\
& \text { Celcius }\end{aligned}$} \\
\hline & G3 & 220 & 18 & \\
\hline & G1 & 205 & 21 & \\
\hline & & & & \\
\hline \multirow{3}{*}{ 05/03/1999 } & $\begin{array}{l}\mathrm{H3} \\
\mathrm{H2}\end{array}$ & $\begin{array}{l}195 \\
250\end{array}$ & $\begin{array}{l}20 \\
19\end{array}$ & \multirow{3}{*}{$\begin{aligned} \text { Temp }= & \text { Temperature } \\
& \text { in Degrees Celcius }\end{aligned}$} \\
\hline & $\mathrm{H} 1$ & 260 & 19 & \\
\hline & $\mathrm{H} 4$ & 280 & 18 & \\
\hline \multirow[t]{5}{*}{ 05/03/1999 } & K8 & 285 & 16 & \multirow{5}{*}{$\begin{aligned} \text { na }= & \text { not avaliable } \\
& \text { (for dry or unmeasured } \\
& \text { stream station) }\end{aligned}$} \\
\hline & K4 & 300 & 20 & \\
\hline & K10 & 300 & 19 & \\
\hline & K9 & 300 & 20 & \\
\hline & K1 & 395 & 14 & \\
\hline
\end{tabular}




\section{Appendix B: Temperature and Specific Conductivity Data}

\begin{tabular}{|c|c|c|c|c|c|c|c|}
\hline Date & $\frac{c}{\frac{\sigma}{\sigma}}$ & ڤ & $\underset{\leftarrow}{\stackrel{\varrho}{g}}$ & Date & $\begin{array}{l}\frac{5}{\frac{0}{0}} \\
\frac{\pi}{\omega}\end{array}$ & U & 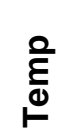 \\
\hline \multirow[t]{8}{*}{ 04/25/1999 } & J4 & 110 & 9 & 06/16/1999 & J1 & na & na \\
\hline & J5 & 108 & 10 & & J2 & na & na \\
\hline & J6 & 102 & 10 & & J3 & na & na \\
\hline & J7 & 102 & 10 & & J4 & na & na \\
\hline & J8 & 105 & 10 & & J5 & na & na \\
\hline & J9 & 182 & 12 & & J6 & na & na \\
\hline & J10 & 220 & 11 & & J7 & na & na \\
\hline & & & & & J8 & na & na \\
\hline \multirow[t]{15}{*}{ 04/29/1999 } & J1 & 118 & 11 & & J9 & 340 & 16 \\
\hline & J2 & 115 & 11 & & J10 & 320 & 17 \\
\hline & J3 & 110 & 11 & & J11 & 335 & 17 \\
\hline & J4 & 98 & 12 & & J12 & 410 & 17 \\
\hline & J5 & 110 & 12 & & J14 & 400 & 16 \\
\hline & J6 & 115 & 11 & & J15 & 379 & 17 \\
\hline & J7 & 117 & 11 & & & & \\
\hline & J8 & 110 & 12 & 08/07/1999 & J2 & na & na \\
\hline & J9 & 298 & 12 & & J3 & na & na \\
\hline & J10 & 290 & 13 & & J4 & na & na \\
\hline & J11 & 295 & 15 & & J5 & na & na \\
\hline & J12 & 295 & 15 & & J6 & na & na \\
\hline & J14 & 270 & 15 & & J7 & na & na \\
\hline & J15 & 300 & 16 & & J8 & na & na \\
\hline & & & & & J9 & na & na \\
\hline \multirow[t]{13}{*}{ 05/21/1999 } & J2 & 120 & 15 & & J10 & na & na \\
\hline & J3 & 125 & 14 & & J11 & 315 & 24 \\
\hline & J4 & 125 & 15 & & J12 & 380 & 19 \\
\hline & J5 & 120 & 15 & & J14 & 430 & 21 \\
\hline & J6 & 155 & 16 & & J15 & 380 & 25 \\
\hline & J7 & 122 & 15 & & & & \\
\hline & J8 & 160 & 16 & & & & \\
\hline & J9 & 325 & 16 & & & & \\
\hline & J10 & 280 & 17 & & & & \\
\hline & J11 & 335 & 17 & & & & \\
\hline & J12 & 320 & 20 & & & & \\
\hline & J14 & 335 & 17 & & & & \\
\hline & J15 & 380 & 16 & & & & \\
\hline
\end{tabular}




\section{Appendix B: Temperature and Specific Conductivity Data}

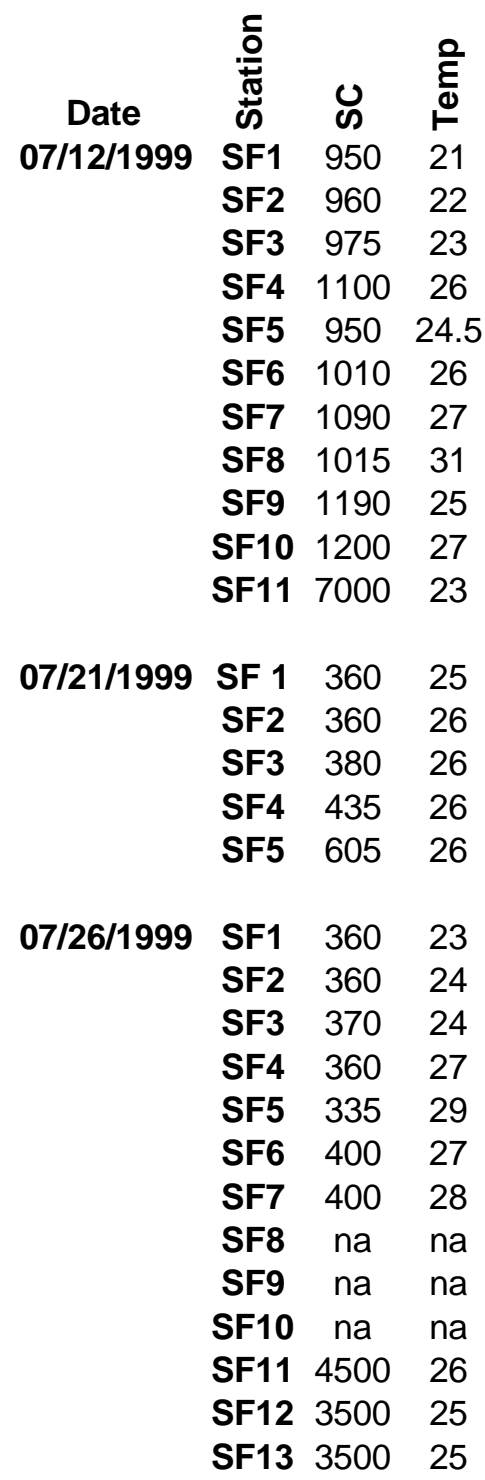


Appendix B: Temperature and Specific Conductivity Data

\begin{tabular}{|c|c|c|c|}
\hline \multirow{2}{*}{$\begin{array}{c}\text { Date } \\
06 / 11 / 1999\end{array}$} & $\frac{\frac{5}{0}}{\frac{\pi}{\pi}}$ & U & 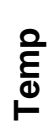 \\
\hline & S2-1 & 218 & 26 \\
\hline & S2-2 & 255 & 26 \\
\hline & S2-3 & 282 & 24 \\
\hline & S2-4 & 240 & 25 \\
\hline & S2-5 & 275 & 25 \\
\hline & S2-6 & 280 & 25 \\
\hline 06/16/1999 & $\mathrm{S} 12$ & 240 & 16 \\
\hline & S9 & 240 & 16 \\
\hline & S7 & na & na \\
\hline & S5 & na & na \\
\hline & S3 & na & na \\
\hline & S1 & na & na \\
\hline & S1a & 360 & 13 \\
\hline
\end{tabular}


Appendix B: Temperature and Specific Conductivity Data

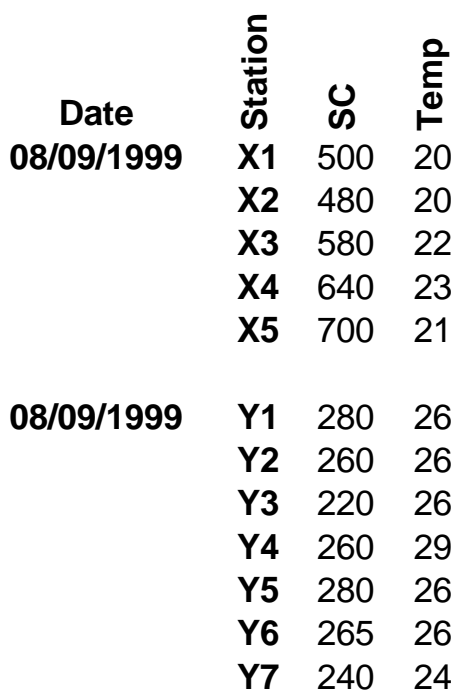


Appendix C: Drainage basin areas for individual monitoring stations

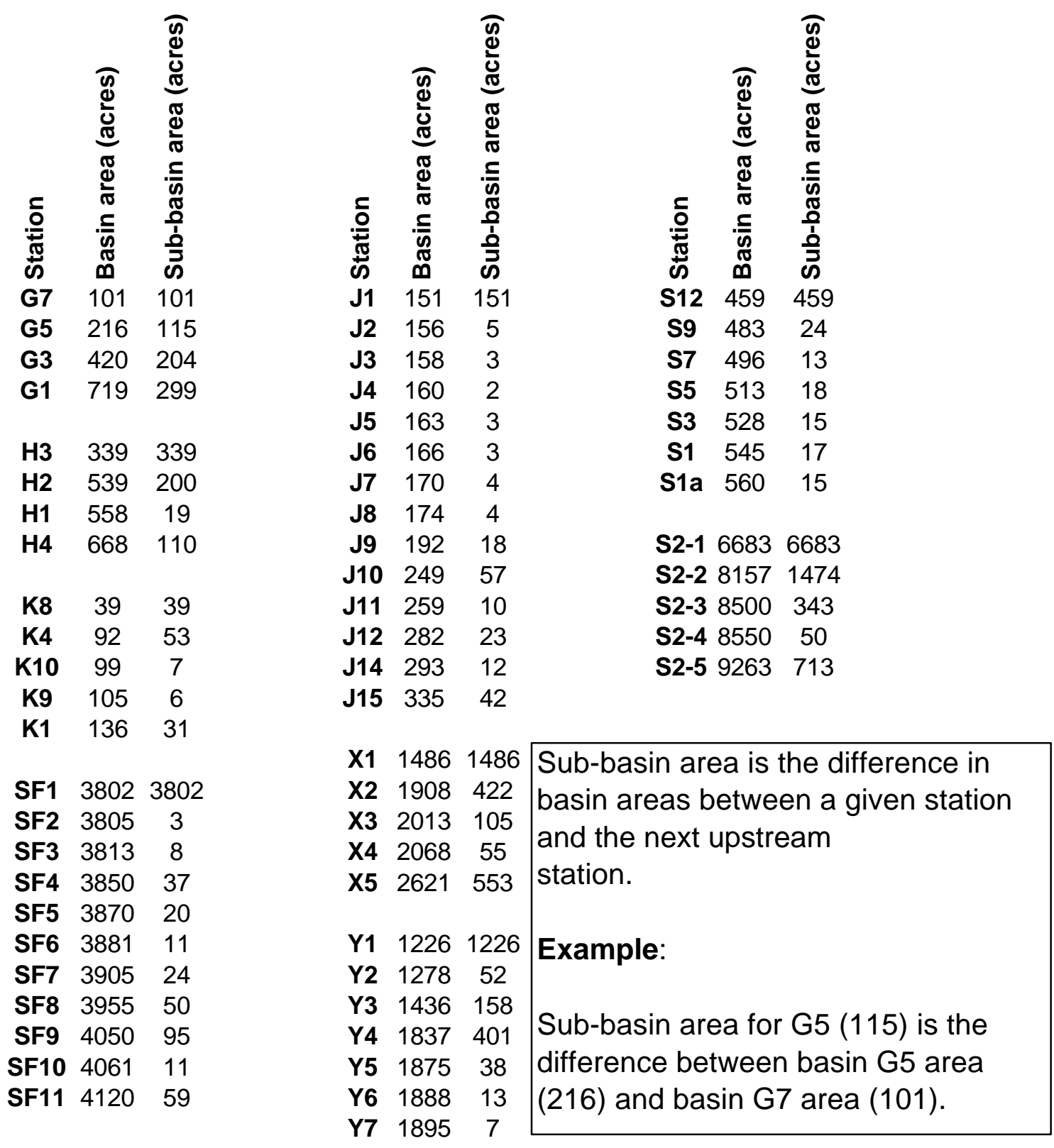




\section{Appendix D: Wolman Pebble Count Data}

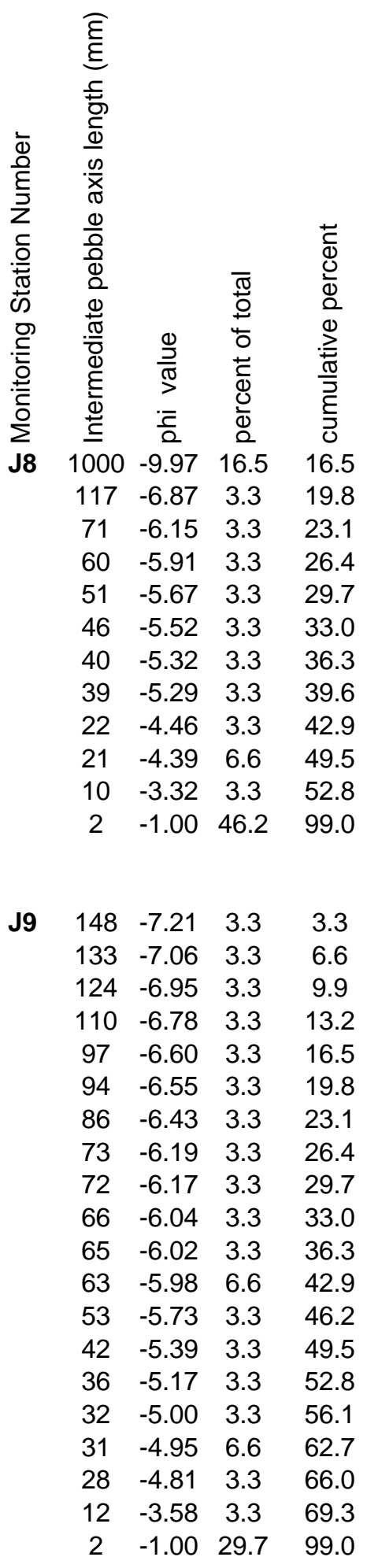

Stream $\mathrm{J}$ measurements taken 8/11/99
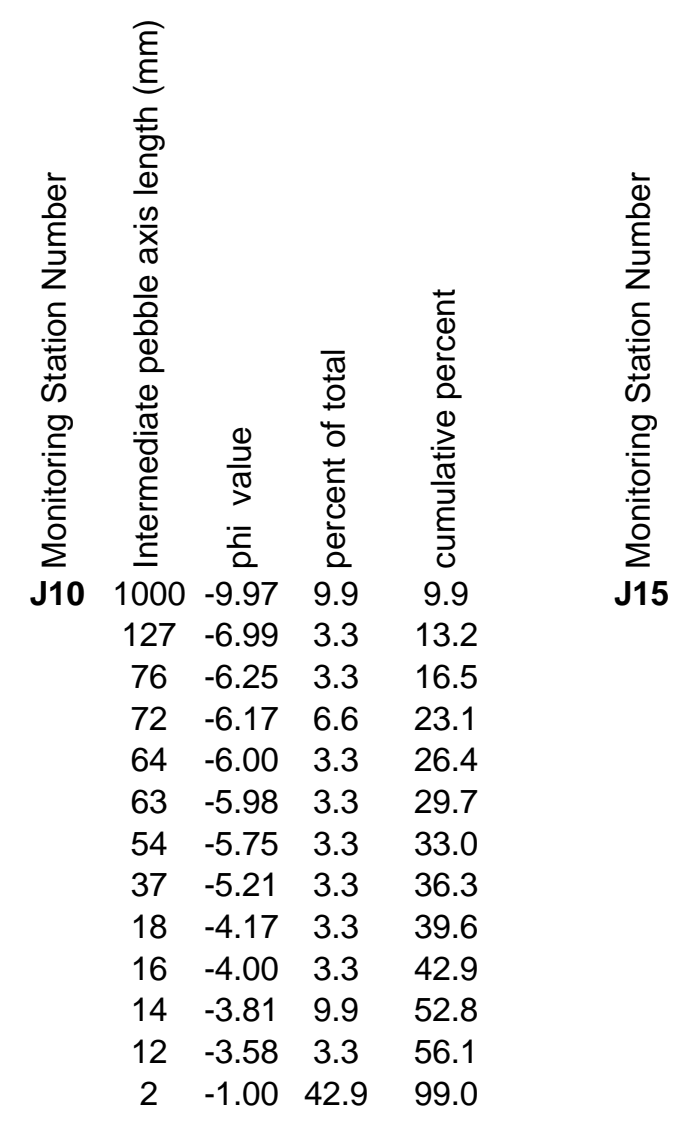

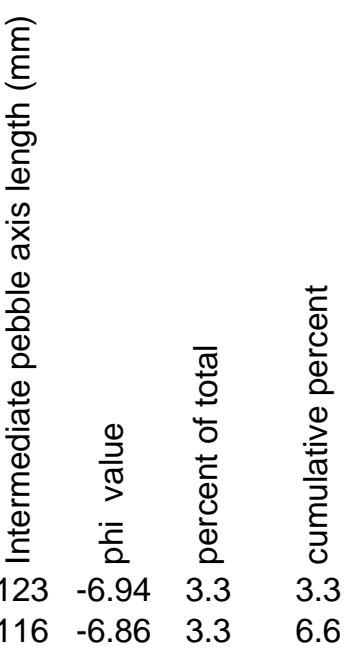

$\begin{array}{llll}91 & -6.51 & 3.3 & 9.9\end{array}$

$\begin{array}{llll}90 & -6.49 & 3.3 & 13.2\end{array}$

$\begin{array}{llll}88 & -6.46 & 3.3 & 16.5\end{array}$

$\begin{array}{llll}81 & -6.34 & 3.3 & 19.8\end{array}$

$\begin{array}{llll}73 & -6.19 & 3.3 & 23.1\end{array}$

$\begin{array}{llll}70 & -6.13 & 3.3 & 26.4\end{array}$

$\begin{array}{llll}65 & -6.02 & 3.3 & 29.7\end{array}$

$\begin{array}{llll}64 & -6.00 & 3.3 & 33.0\end{array}$

$\begin{array}{llll}61 & -5.93 & 3.3 & 36.3\end{array}$

$\begin{array}{llll}60 & -5.91 & 3.3 & 39.6\end{array}$

$\begin{array}{llll}51 & -5.67 & 6.6 & 46.2\end{array}$

$\begin{array}{llll}44 & -5.46 & 3.3 & 49.5\end{array}$

$\begin{array}{llll}43 & -5.43 & 6.6 & 56.1\end{array}$

$\begin{array}{llll}34 & -5.09 & 3.3 & 59.4\end{array}$

$\begin{array}{llll}33 & -5.04 & 3.3 & 62.7\end{array}$

$\begin{array}{llll}32 & -5.00 & 3.3 & 66.0\end{array}$

$\begin{array}{llll}30 & -4.91 & 3.3 & 69.3\end{array}$

$\begin{array}{lllll}\mathbf{J} 12 & 1000 & -9.97 & 57 & 57.0\end{array}$

$\begin{array}{llll}12 & -3.58 & 6.6 & 63.6\end{array}$

$\begin{array}{llll}29 & -4.86 & 3.3 & 72.6\end{array}$

$\begin{array}{llll}26 & -4.70 & 3.3 & 75.9\end{array}$

$\begin{array}{llll}22 & -4.46 & 3.3 & 79.2\end{array}$

$\begin{array}{llll}19 & -4.25 & 3.3 & 82.5\end{array}$

$\begin{array}{llll}18 & -4.17 & 3.3 & 85.8\end{array}$

$\begin{array}{llll}17 & -4.09 & 6.6 & 92.4\end{array}$

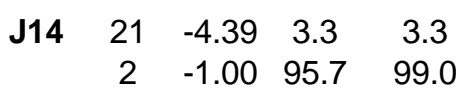

For Stream J, stations J1 - J7 could not be measured for pebble count because the installation of the weirs at those points altered the natural stream morphology and sediments. 


\section{Appendix D: Wolman Pebble Count Data}

Stream K measurements taken 8/18/99
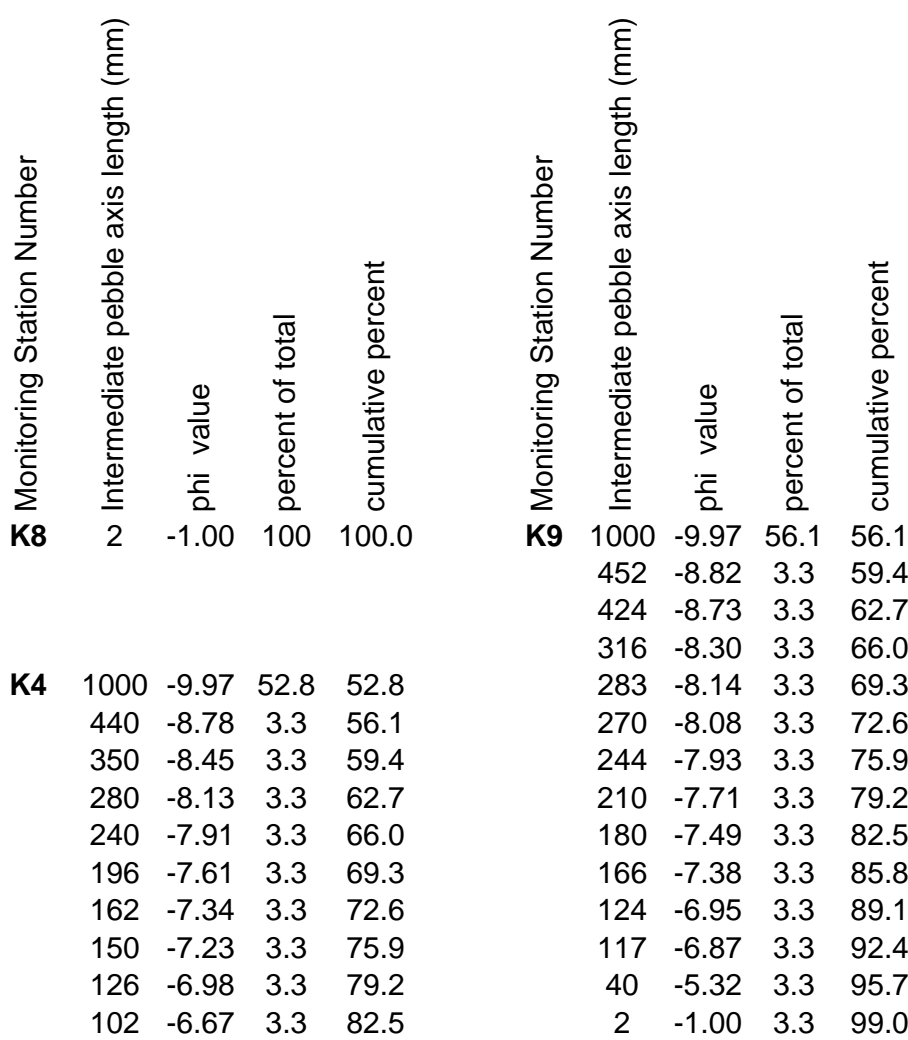

\begin{tabular}{|c|c|c|c|}
\hline 184 & -7.52 & 3.3 & 3.3 \\
\hline 180 & -7.49 & 3.3 & 6.6 \\
\hline 175 & -7.45 & 6.6 & 13.2 \\
\hline 163 & -7.35 & 3.3 & \\
\hline 127 & -6.99 & 3.3 & \\
\hline 126 & -6.98 & 3.3 & \\
\hline 112 & -6.81 & 3.3 & \\
\hline 93 & -6.54 & 3.3 & \\
\hline 87 & -6.44 & 3.3 & \\
\hline 84 & -6.39 & 3.3 & \\
\hline 76 & -6.25 & 3.3 & \\
\hline 66 & -6.04 & 3.3 & \\
\hline 63 & -5.98 & 3.3 & \\
\hline 58 & -5.86 & 3.3 & \\
\hline 55 & -5.78 & 6.6 & 56. \\
\hline 50 & -5.64 & 3.3 & \\
\hline 44 & -5.46 & 3.3 & \\
\hline 33 & -5.04 & 3.3 & 66. \\
\hline 32 & -5.00 & 3.3 & 69 \\
\hline 31 & -4.95 & 3.3 & 72 \\
\hline 29 & -4.86 & 3.3 & 75. \\
\hline 23 & -4.52 & 3.3 & 79 \\
\hline 22 & -4.46 & 3.3 & 82 \\
\hline 12 & -3.58 & 3.3 & \\
\hline 2 & -1.00 & 13.2 & \\
\hline
\end{tabular}




\section{Appendix D: Wolman Pebble Count Data}

Stream S measurements taken 8/11/99

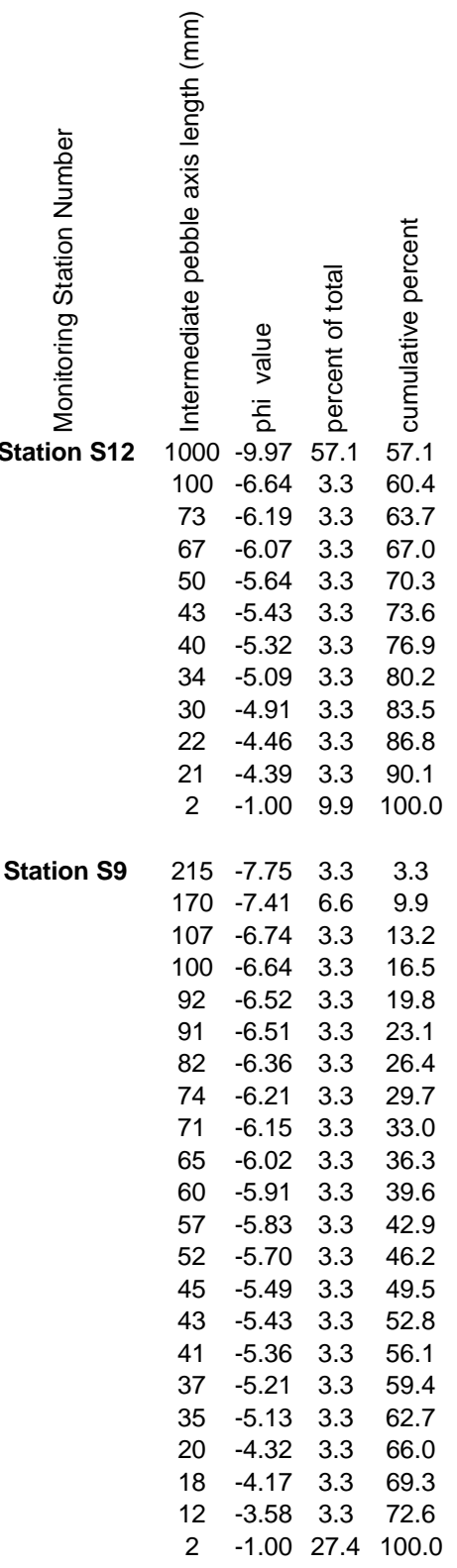

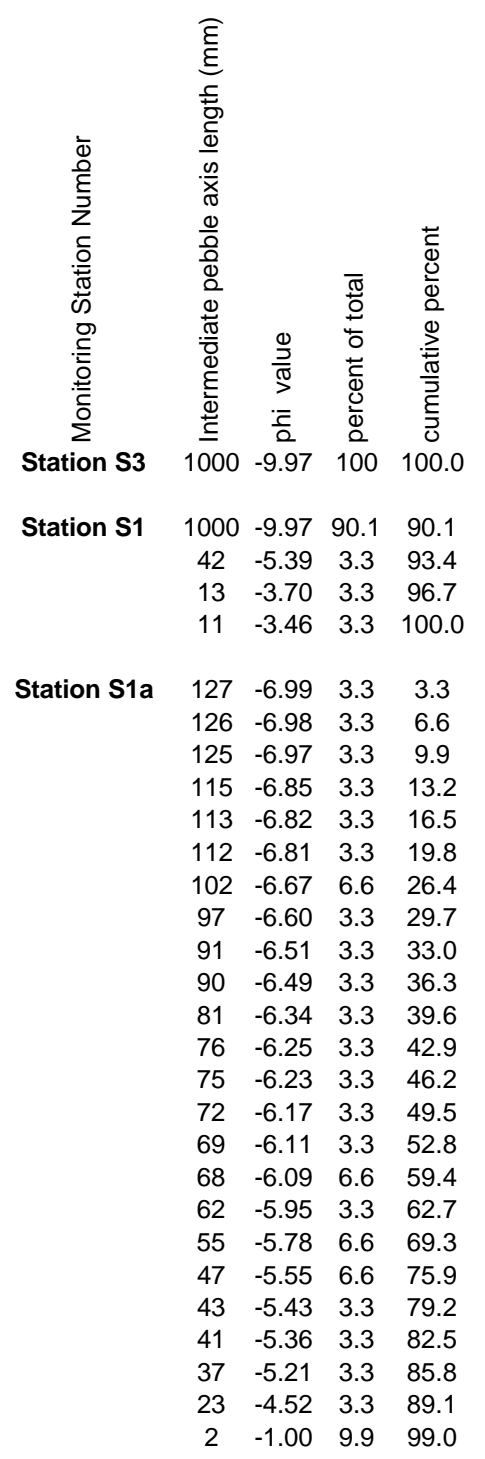


Appendix D: Wolman Pebble Count Data

Stream $Y$ measurements taken 8/18/99

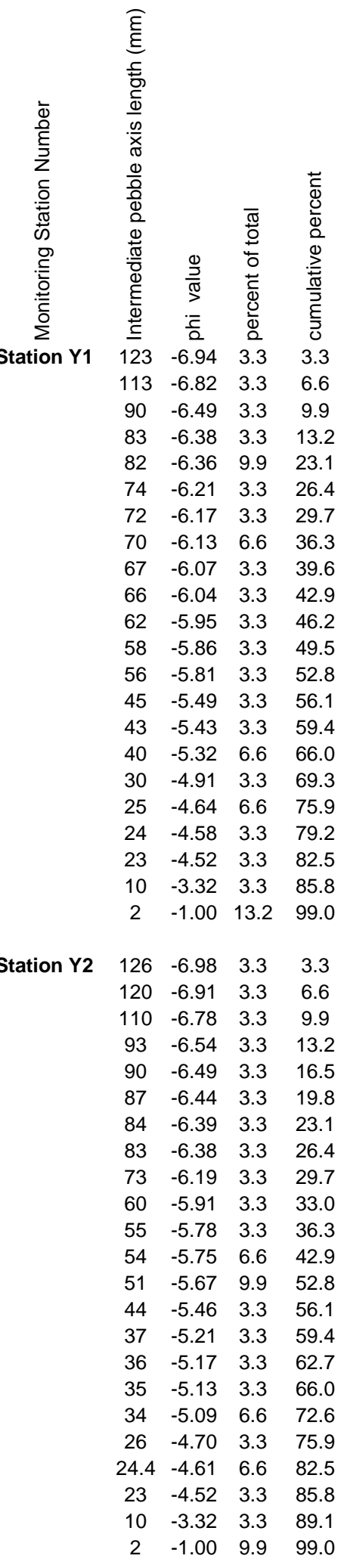




\section{Appendix D: Wolman Pebble Count Data}

Stream X measurements taken 8/18/99
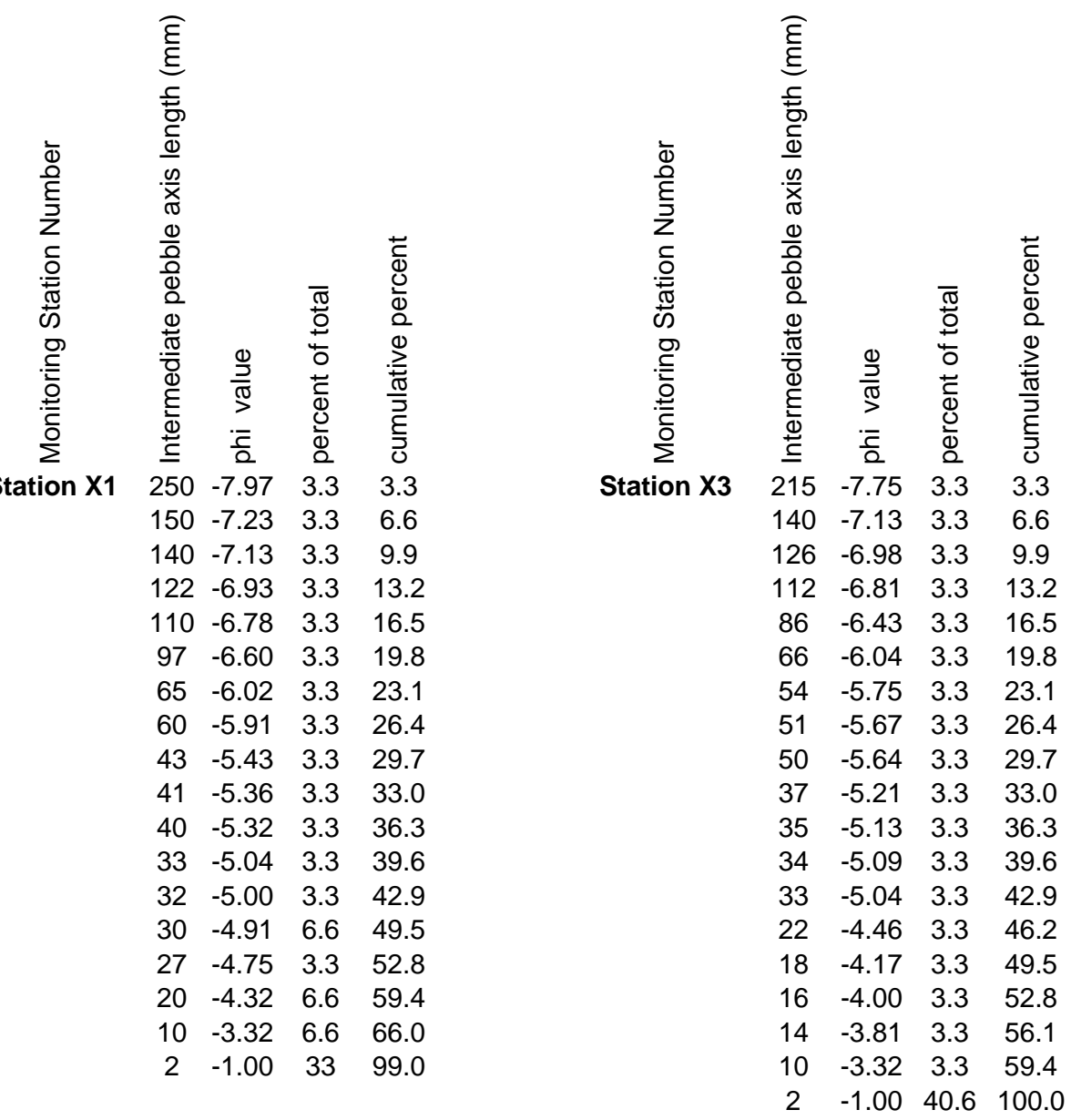

$\begin{array}{lllll}\text { Station X2 } & 260 & -8.02 & 3.3 & 3.3\end{array}$

Station X4 $1000 \quad-9.97 \quad 59.4 \quad 59.4$

$\begin{array}{llll}146 & -7.19 & 3.3 & 62.7\end{array}$

$\begin{array}{llll}96 & -6.58 & 3.3 & 66.0\end{array}$

$\begin{array}{llll}39 & -5.29 & 3.3 & 69.3\end{array}$

$\begin{array}{llll}31 & -4.95 & 3.3 & 72.6\end{array}$

$\begin{array}{llll}28 & -4.81 & 3.3 & 75.9\end{array}$

$\begin{array}{llll}20 & -4.32 & 3.3 & 79.2\end{array}$

$\begin{array}{llll}2 & -1.00 & 19.8 & 99.0\end{array}$

$\begin{array}{llll}92 & -6.52 & 3.3 & 26.4\end{array}$

$\begin{array}{llll}80 & -6.32 & 3.3 & 33.0\end{array}$

$\begin{array}{llll}76 & -6.25 & 3.3 & 36.3\end{array}$

$\begin{array}{llll}70 & -6.13 & 3.3 & 39.6\end{array}$

$\begin{array}{llll}61 & -5.93 & 3.3 & 42.9\end{array}$

$\begin{array}{llll}60 & -5.91 & 6.6 & 49.5\end{array}$

$\begin{array}{llll}50 & -5.64 & 6.6 & 56.1\end{array}$

$\begin{array}{llll}47 & -5.55 & 3.3 & 59.4\end{array}$

$\begin{array}{llll}45 & -5.49 & 3.3 & 62.7\end{array}$

$\begin{array}{llll}41 & -5.36 & 3.3 & 66.0\end{array}$

$\begin{array}{llll}33 & -5.04 & 3.3 & 69.3\end{array}$

$\begin{array}{llll}30 & -4.91 & 3.3 & 72.6\end{array}$

$\begin{array}{llll}21 & -4.39 & 6.6 & 79.2\end{array}$

$\begin{array}{llll}20 & -4.32 & 3.3 & 82.5\end{array}$

$\begin{array}{llll}16 & -4.00 & 3.3 & 85.8\end{array}$

$\begin{array}{llll}2 & -1.00 & 13.2 & 99.0\end{array}$

$\begin{array}{lllll}\text { Station X5 } & 132 & -7.04 & 3.3 & 3.3\end{array}$

$\begin{array}{llll}112 & -6.81 & 3.3 & 6.6\end{array}$

$\begin{array}{llll}95 & -6.57 & 9.9 & 16.5\end{array}$

$\begin{array}{llll}70 & -6.13 & 3.3 & 19.8\end{array}$

$\begin{array}{llll}69 & -6.11 & 3.3 & 23.1\end{array}$

$\begin{array}{llll}67 & -6.07 & 3.3 & 26.4\end{array}$

$\begin{array}{llll}62 & -5.95 & 3.3 & 29.7\end{array}$

$\begin{array}{llll}50 & -5.64 & 3.3 & 33.0\end{array}$

$\begin{array}{llll}40 & -5.32 & 6.6 & 39.6\end{array}$

$\begin{array}{llll}38 & -5.25 & 3.3 & 42.9\end{array}$

$\begin{array}{llll}29 & -4.86 & 3.3 & 46.2\end{array}$

$\begin{array}{llll}27 & -4.75 & 6.6 & 52.8\end{array}$

$\begin{array}{llll}17 & -4.09 & 3.3 & 56.1\end{array}$

$\begin{array}{llll}2 & -1.00 & 42.9 & 99.0\end{array}$ 
Appendix E: Alluvium Thickness Data.

\begin{tabular}{|c|c|c|c|c|c|c|c|}
\hline 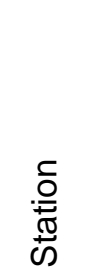 & 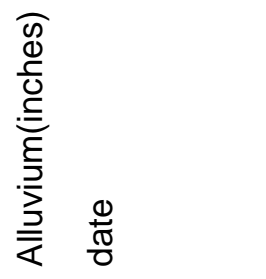 & 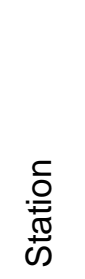 & 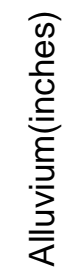 & $\frac{0}{\frac{\pi}{0}}$ & 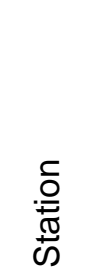 & 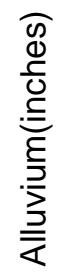 & $\frac{\Phi}{\frac{\pi}{0}}$ \\
\hline H3 & 16 05/03/1999 & J2 & 35 & 05/21/1999 & $\mathrm{S} 12$ & 2 & $06 / 11 / 1999$ \\
\hline $\mathrm{H} 2$ & 16 & J3 & 14 & & S9 & 34 & \\
\hline $\mathrm{H} 1$ & 20 & J4 & 37 & & S7 & 17 & \\
\hline \multirow[t]{2}{*}{$\mathrm{H} 4$} & 16 & J5 & 21 & & S5 & 0 & \\
\hline & & J6 & 15 & & S3 & 0 & \\
\hline G7 & 12 05/03/1999 & J7 & 17 & & S1 & 0 & \\
\hline G5 & 8 & J8 & 4 & & S1a & 44 & \\
\hline G3 & 2 & J9 & 19 & & & & \\
\hline \multirow[t]{2}{*}{ G1 } & 0 & J10 & 9 & & & & \\
\hline & & $\mathrm{J} 11$ & 0 & & & & \\
\hline K8 & 14 05/03/1999 & J12 & 0 & & & & \\
\hline K4 & 6 & J14 & 2 & & & & \\
\hline K10 & 5 & $\mathrm{~J} 15$ & 20 & & & & \\
\hline K9 & 3 & & & & & & \\
\hline \multirow[t]{2}{*}{$\mathrm{K} 1$} & 22 & $\mathrm{X} 1$ & 14.7 & 08/09/1999 & & & \\
\hline & & $\mathrm{X} 2$ & 13.8 & & & & \\
\hline SF1 & 18 07/12/1999 & $\mathrm{X} 3$ & 9.48 & & & & \\
\hline SF2 & 18 & $\mathrm{X} 4$ & 0 & & & & \\
\hline SF3 & 16 & $\mathrm{X} 5$ & 2.4 & & & & \\
\hline SF4 & 0 & & & & & & \\
\hline SF5 & 4 & Y1 & 15.6 & 08/09/1999 & & & \\
\hline SF6 & 5.6 & Y2 & 36 & & & & \\
\hline SF7 & 10 & Y3 & 7.2 & & & & \\
\hline SF8 & 7.3 & Y4 & 0 & & & & \\
\hline SF9 & 2 & Y5 & 27 & & & & \\
\hline SF10 & 2 & Y6 & 23 & & & & \\
\hline SF11 & 2 & Y7 & 20 & & & & \\
\hline SF12 & 3 & & & & & & \\
\hline SF13 & 0 & & & & & & \\
\hline
\end{tabular}

